\title{
REGIONAL CONTRIBUTIONS TO ACHIEVING SUSTAINABILITY - AN EXAMINATION USING SUSTAINABILITY-FOCUSED POLICIES IN REGIONAL OFFICIAL PLANS
}

\author{
by \\ Elisabeth Perlikowski \\ Bachelor of Industrial Engineering, Technical University of Nova Scotia, \\ 1994

\begin{abstract}
A Project Paper presented to Ryerson University in partial fulfillment of the requirements for the degree of Master of Applied Science in the Program of Environmental Applied Science and Management
\end{abstract}

Toronto, Ontario, Canada, 2010

CElisabeth Perlikowski 2010 


\section{Author's Declaration}

I hereby declare that I am the sole author of the project paper.

I authorize Ryerson University to lend this project paper to other institutions or individuals for the purpose of scholarly research.

I niversity to reproduce this project paper by $\mathrm{p} \quad$ ins, in total or in part, at the request of other institutions or individuals for the purpose of scholarly research. 


\title{
Regional Contributions to Achieving Sustainability - An Examination Using Sustainability-Focused Policies in the Regional Official Plans, Master of Applied Science, 2010 Elisabeth Perlikowski, Environmental Applied Science and Management, Ryerson University
}

\begin{abstract}
This research examines the policy content of the Regional Official Plans in order to provide insight whether the regions of York and Peel are moving towards achieving sustainability. The study's exploratory qualitative and comparative analysis examines the Regions' contributions using the planning policies outlined in the recently released Regional Official Plans. Findings suggest that the Regions have emphasized sustainability-focused policies and have laid a foundation in achieving environmental and economic elements of sustainability. The analysis shows a low occurrence of policies that integrate social equity and justice issues with the economic and environmental objectives, which reduces the prospect of achieving sustainability. The comparative analysis suggests a number of directives that further can decrease the move towards achieving sustainability, including voluntary policies and indicators that may mislead a community in its progress towards sustainability. The study found that the Region of Peel has a higher presence of factors that can weaken the chances of achieving sustainability.
\end{abstract}




\section{Table of Contents}

Chapter 1: Introduction 1

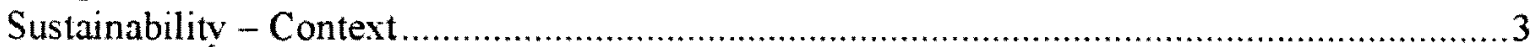

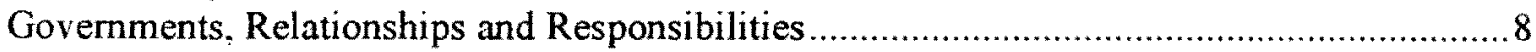

Ontario Sustainable Legislation - Context ..................................................................... 9

Government and Public Support of the Places to Grow Act ................................................ 10

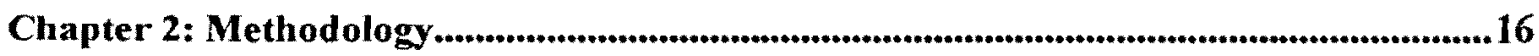

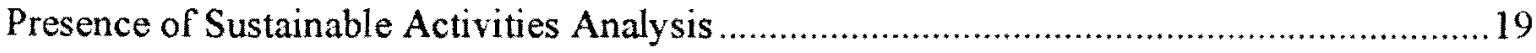

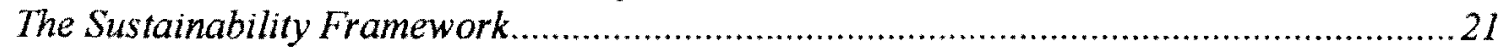

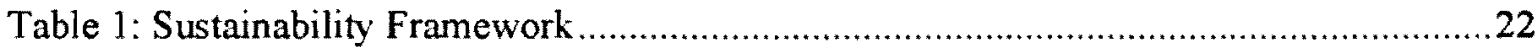

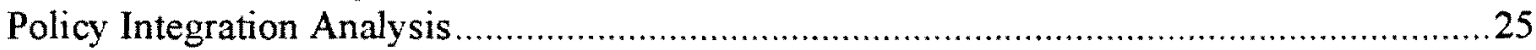

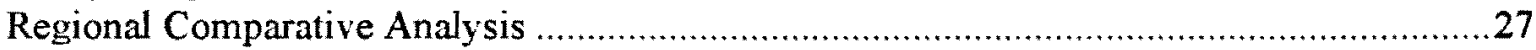

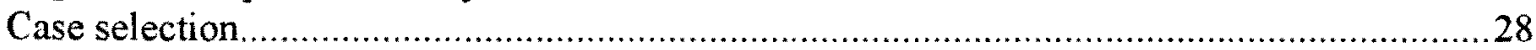

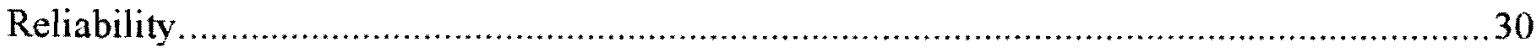

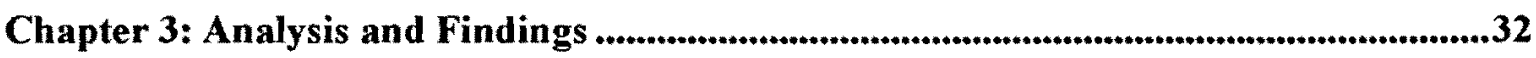

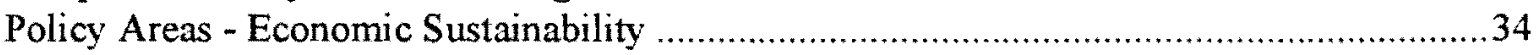

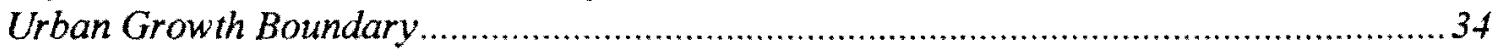

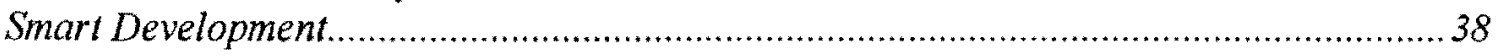

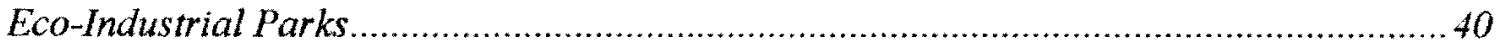

Purchase of Development Rights ............................................................................ 4

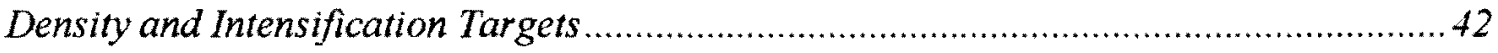

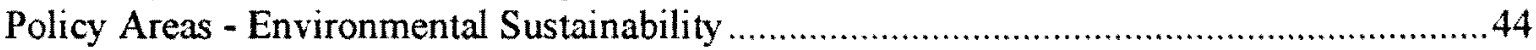

Identify and Protect the Environment ........................................................................ 44

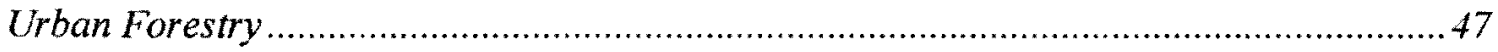

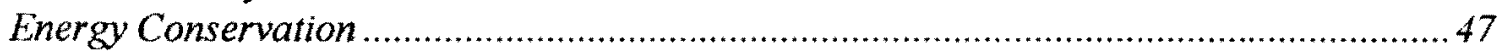

Water Source Protection and Water Conservation ....................................................... 49

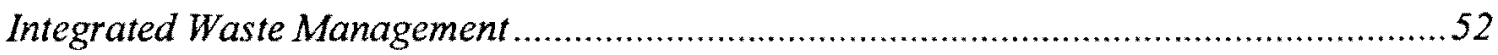

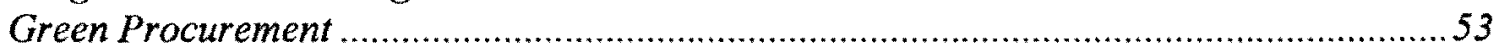

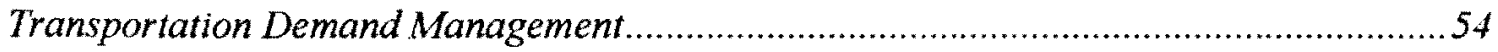

Pedestrian and Bicycle Access Plans .............................................................55

Public Education of Unsustainable Practices and the Environment...............................56

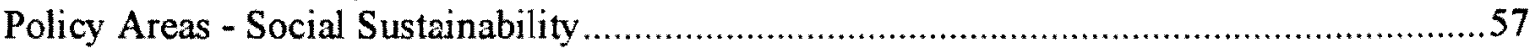

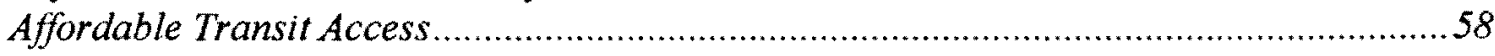

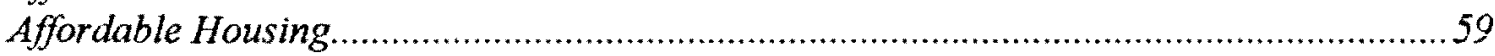

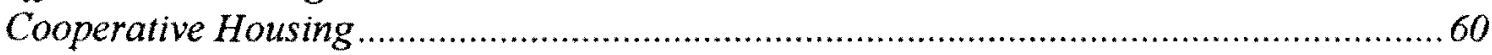

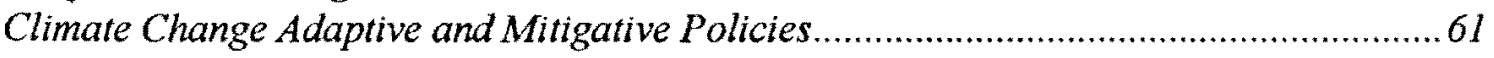

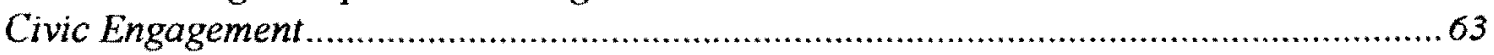

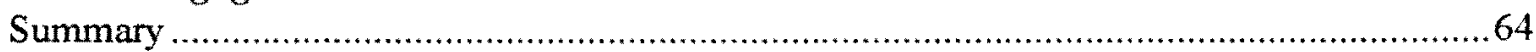

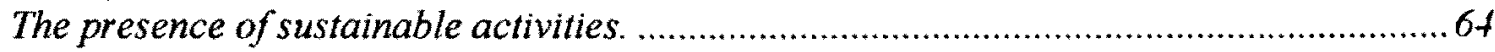

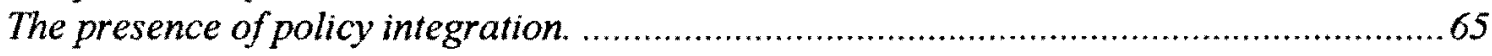

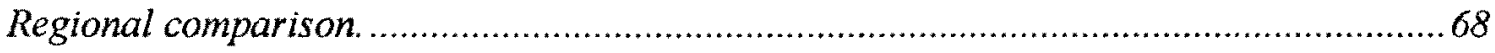

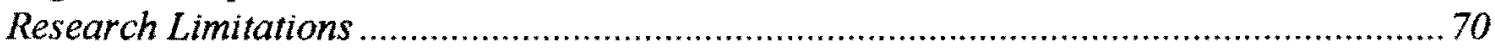

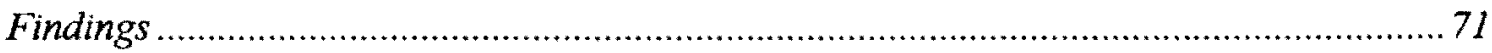

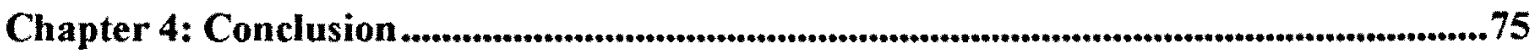

Appendix A: Federal, Provincial and Municipal Governments Responsibilities .................. 79 


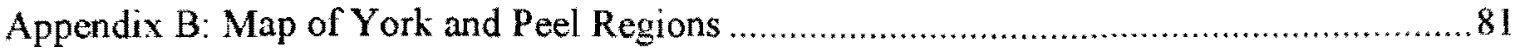

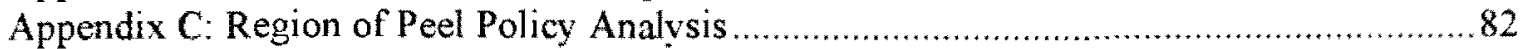

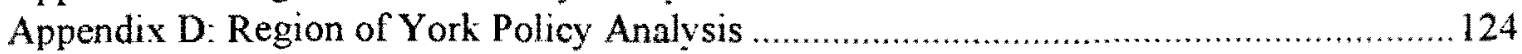

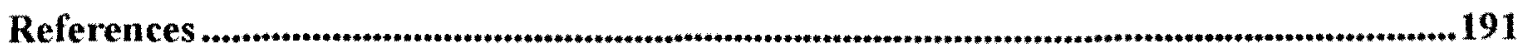

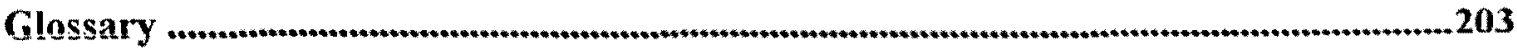




\section{List of Tables}

Table

Page

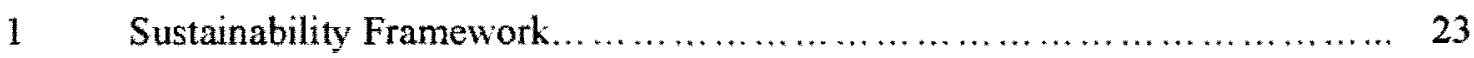

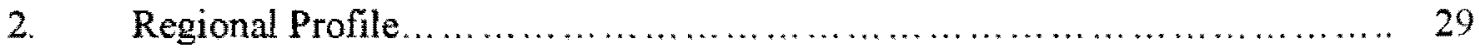

3. Presence of Sustainable Activities.................................. 34

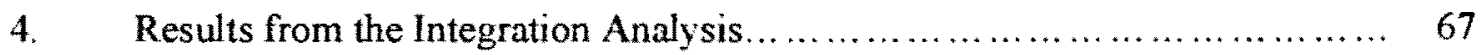




\section{Table of Abbreviations}

ICLEI: International Council for Local Environmental Initiatives

IDRC: Intemational Development Research Centre

INEP: United Nations Environment Program 


\section{Chapter 1: Introduction}

Most scientists and international bodies that foresee serious consequences such as environmental degradation, social ailments and poor economic development do not advocate a complete halt in the use of natural resources. However, they do believe that society should consider the planet's limits and the global consequences that unsustainable patterns can have (Boyd and Suzuki, 2008; Chakrabarty, 2001 cited in World Bank, 1991 and Cheema, 1993; ICLEI, IDRC and UNEP, 1996; Hammond, 2006; Hempel, 1996; Meadows et al., 2005; Roseland, 2005; United Nations Environment Program, 2009; WCED, 1987). They believe that global environmental protection and sustainability begins:

- With industrialized nations, which account for a higher share of the world's resource use, energy consumption and environmental pollution.

- In urban areas, as urbanization and the economic development status of a country are closely linked, and the urban population is on the rise, requiring sustainable solutions.

- At the community level, which is "the level where complex living systems are most interdependent and vulnerable" (Hempel, 1996, 6 cited in Orr, 1992 and Sale, 1985).

As many researchers and international bodies view the concept of sustainability as a long-term solution that needs to be executed at a local level, an increasing number of local governments have begun planning their communities with sustainability in mind. A review of Canadian and American local governments shows that many have been working towards applying the concept of sustainability by implementing local policies, programs and action plans (Berke and Manta Conroy, 2000; Conroy, 2006; Jepson, 2004; Parkinson and Roseland, 2002; Portney, 2002; Saha and Paterson, 2008), although research studies evaluating local governments' progress towards achieving sustainability are finding that performance has 
been limited even when sustainability-focused policies are in place (Tsenkova and Damiani. 2009). Governmental policies represent what the government intends to do or not do to govern its community (Wellington, ES8921), and they play a crucial role in achieving any community goal, such as sustainability. Is it possible to know at the policy-making stage the potential of achieving sustainability? Knowing the direction a community will be taken by government policies before implementing those policies can provide valuable insight and opportunities to create policies with desired results.

Ontario's municipalities have recently tailored their Official Plans to conform with provincial legislation that focuses on sustainable growth and environmental protection, most notably the Places to Grow Act (2005), incorporating sustainability principles and creating sustainability-focused policies in their Official Plans. The Official Plan consists of land-use policies that provide a road map for the community and that is guided by provincial legislation (Ministry of Municipal Affairs and Housing, 2009). The Official Plan needs to be consistent with the Provincial Policy Statement issued under the Planning Act and conform to or not conllict with any applicable provincial plans. The Provincial Policy Statement contains policy directions on matters of provincial interest related to land use planning and development. The Official Plan is reviewed and updated at least every five years, as mandated by the Planning Act, to ensure that the plan implements any changes to the Provincial Policy Statement or other provincial legislation requiring updates to the Official Plan, such as the Places to Grow Act. The five-year review is also an opportunity to ensure the Official Plan continues to address local priorities and changing community needs. The Official Plan is prepared with input from the community and helps to ensure that future planning and development will meet the specific needs of that community. The Official Plans examined during this study have a time horizon of twenty-five years (Ministry of Municipal Affairs and Housing, 2005, 2009). 
The British North America Act in 1867 gave provincial governments powers over municipal governments, and the province of Ontario gives direction to municipalities regarding their responsibilities via provincial legislation. Municipalities are starting to implement their own Official Plans, which are in line with provincial law, and will review them in five years as mandated by the Planning Act (1990). Given the five-year Official Plan review period, and that ex post evaluations of communities with sustainability-focused policies showed limited results in moving communities towards sustainability, this research seeks to examine the policy content of Official Plans in order to provide insight whether two Ontario municipalities, the regions of York and Peel, are moving forward towards achieving sustainability.

\section{Sustainability - Context}

The definition of sustainable development and sustainability is ambiguous (Saha and Paterson, 2008) with over 70 definitions in circulation (Lozano, 2008). The terms sustainable development and sustainability are used interchangeably in the literature reviewed. On the surface, these terms refer to a state "that meets the needs of the present without compromising the ability of future generations to meet their own needs" (WCED, 1987, 1). Sustainable development and sustainability have the same objective of integrating natural, economic, and social systems (Mebratu, 1998) in order to ensure that natural resources, social equity and justice, and economic development are available now and in the future. This paper, similarly to the literature reviewed, uses the terms interchangeably and is guided by the Brundtland Report's (WCED, 1987) definition of sustainable development and sustainability. Although on the surface sustainability appears to be a simple concept of 
making sure that current and future generations have a decent standard of living while living within the limits of natural systems (Berke and Manta Conroy, 2000), putting this idea into practice can be very complex, as it requires dealing with multiple self-organizing systems: the environment, the economy and the society (Dale, 2001). The challenge of sustainability is that there is no simple way to model and predict the interaction of individuals, societies and natural systems (Abolina and Zilans, 2002). This complexity is one of the reasons sustainability has over 70 definitions in circulation but no one working definition (Lozano, 2008). There are common characteristics found in the literature review that can be used to derive a more precise definition. One characteristic is "dynamic". Sustainability consists of self-regulating and contradicting environmental, economic and social systems that continuously change and impact each other. Sustainability requires the community to pursue an evolving and ever-changing approach which allows to evaluate community's state with respect to sustainability as well as ongoing means to negotiate conflicts in order to move a community in the direction of becoming more sustainable (Berke and Manta Conroy, 2000). Another characteristic is "integration" of environmental, economic and social elements of sustainability as without integration sustainability cannot be achieved or sustained (Hempel, 1996; WCED, 1987). The objectives of the three sustainability pillars often contradict and compete with one another (ICLEI, IDRC and UNEP, 1996). Achieving integration usually involves coordination, negotiation and compromise (Berke and Manta Conroy, 2000). The literature on sustainable development has advanced in defining key characteristics of the concept that are relevant to the theory and practice of planning (Berke and Manta Conroy, 2000). Considering the scope of the research, this study's working definition of sustainability is as follows: sustainable development or sustainability is a dynamic process and state in which communities anticipate and accommodate the needs of current and future 


\section{generations in ways that integrate local social, economic and ecological systems (Berke}

and Manta Conroy, 2000).

As mentioned earlier, many researchers (Hempel, 1996; Lozano, 2008; Meadows et al., 2005) view the concept of sustainability as a long-term solution to global environmental degradation, social ailments and economic development. Global environmental degradation includes a reduction in water resources, a reduction in food and energy production, and the destruction and changing of the ecosystem, including biodiversity, all of which impact human and nonhuman nature (Hempel, 1996). The economic element favours market expansion and growth, externalization of costs, and sustained private profit, while social development concerns itself with meeting basic human needs, increasing economic and social equity, and creating community self-reliance (ICLEI, IDRC and UNEP, 1996).

Some associate the state of our current environment with the advances made in the economy and industrialization over the last 100 years (Lozano, 2008), but a historical review of sustainability shows evidence that "ecological factors were key elements in the rise and fall of ancient civilization and in two of the major social transformations, namely, the agricultural and industrial transformations" (Mebratu, 1998, 517). The concept of sustainability can be tracked back to Thomas Robert Malthus (1766-1834), who is considered to be the first economist to foresee the limits to growth caused by resource scarcity (Mebratu, 1998). In the twentieth century, researchers such as Meadows (1972) evaluated nature's carrying capacity and society's needs and wants in the Limits to Growth model. However, it was the Brundtland Report (WCED, 1987) that brought the idea of sustainability to the mainstream with its definition of sustainable development.

Although sustainable development has been proposed as a solution to integrate sociopolitical decisions with the environment, this concept is not without deficiencies and concerns. Sustainability has over 70 definitions in circulation but there is no agreed-upon 
working definition (Lozano, 2008). Some interpret the concept as being growth-oriented and that it does not place sufficient emphasis on limiting growth and consumption (Robinson. 2008 cited in Sachs, 1999). Others believe that sustainability efforts in an industrialized country can limit the potential for developing countries to prosper (Robinson, 2008 cited in Banerjee, 2003 and Carruthers, 2001). Lastly, the concept might bring difficulties to communities that have historically relied on natural resources for their well-being (Pierce and Dale, 1999).

Many environmentalists will point out that rapid responses are required to deal with global environmental problems but according to Hempel (1996) human responses are determined less by the need for action than by the complexity of cultural, political and economic institutions through which action is organized. As Hempel says, "For sustainability to be acted upon, it must be possible for the desirability of environmental and socio-political characteristics of the world to be expressed in the political realm" $(1996,9)$. Many researchers and institutions, including Hempel (1996), Roseland (2005), ICLEI, IDRC and UNEP (1996), and the ICLEI (2010), believe that global environmental protection and sustainability begins at the community level, which is "the level where complex living systems are most interdependent and vulnerable (Hempel, 1996, 6 cited in Orr, 1992 and Sale, 1985). Many have identified local governments to be in the best position to drive their communities to sustainability (Federation of Canadian Municipalities, 2009; Hempel, 1996; ICLEI, IDRC and UNEP 1996; Roseland, 2005). The local level of government was created in Canada to provide infrastructure services such as transportation and traffic management, water, wastewater and waste management, and land-use planning to their communities (Tindal and Tindal, 2004). Roseland (2005) refers to these services as sustainability building blocks and believes that local governments' insights into their communities' needs makes them critical in the movement towards sustainability. 
This research concentrates on Canada which, as a developed country, accounts for a disproportionate share of the world's resource use, energy consumption and environmental pollution (Boyd and Suzuki, 2008; WCED, 1987). Environmentally unsustainable practices in developed countries originate in housing, food and transportation, which make up $80 \%$ of the ecological footprint of people living in industrialized nations (Boyd and Suzuki, 2008). This research also focuses on an urban area in Canada, as studies show that urbanization and the economic development status of a country are closely linked, and that the world's urban population is on the rise (Chakrabarty, 2001 cited in World Bank, 1991 and Cheema, 1993; United Nations Department of Economic and Social Affairs, 2007).

Urbanization, without proper focus and policies creates unsustainable communities with escalating land prices, pollution and deterioration of the urban environment (Chakrabarty, 2001). The world's urban population is increasing at a very fast pace; in 2005, $74 \%$ of the population of the more developed regions was urban, and this number is projected to reach $81 \%$ by 2030 (United Nations Department of Economic and Social Affairs, 2007). According to Statistics Canada (2006), 80\% of all Canadians lived in an urban area as of 2006. The Places to Grow Act (2005) forecasts that some of the Greater Golden Horseshoe regions' populations are expected to increase by $30 \%$ to $40 \%$ by 2031 (see Table 2 :

Community Profile for current and forecasted population). This expected growth will place more pressure on the surrounding ecosystem as demand for additional housing increases, which can be a driver for more urbanization and consumption of natural resources (Tarasofsky, 2006).

As urban areas experience such unprecedented population growth, they carry a great deal of responsibility and power in achieving sustainable communities and in determining whether they will provide future generations with the ability to meet their own needs. 


\section{Governments, Relationships and Responsibilities}

The need for local governments in Canada became evident in the 1830 s when many communities in Canada were still governed by more senior levels of government. A local level of government was created to provide infrastructure services such as roads, water and waste management, and land planning to communities (Tindal and Tindal, 2004). Today, the Canadian government is made up of the federal, provincial and municipal governments, whose responsibilities were divided in the British North America Act in 1867 . The federal government's ability to affect sustainability can be found in its powers over waters, fisheries, the regulation of trade and commerce, its system of taxation and its influence on peace, order and good government. The provincial government has powers over natural resources and the environment, property, civil rights, local works and undertakings, and over municipal institutions. Municipal government's “... functions, finances, governing structure - even their very existence - depend upon provincial authority" (Tindal and Tindal, 2004, 10), and Hodge $(2003,98)$ explains that "it is common to find municipalities referred to as 'creatures' of the provincial government." Appendix A lists provincial responsibilities and what the province has mandated as the responsibilities of municipalities, which are further divided between upper-tier and lower-tier municipal governments. Depending on the community size and its history, a municipal government can have multiple levels. A local municipality may be called a city, a town, a township or a village. They are also referred to as "lower tier" municipalities when there is another level of municipal government like a county or region involved in providing services. A county or regional government is a federation of the local municipalities within its boundaries. Where there is only one level of municipal government in an area, it is called a single tier municipality (Ministry of Municipal Affairs and Housing, 2010). 


\section{Ontario Sustainable Legislation - Context}

Since the election of the Ontario McGuinty Liberal government in 2003, there has been a significant shift in policy regime from the Harris/Eves Progressive Conservative government (1995-2003), regarding growth management and sustainability issues. The province has introduced a range of legislation mandating that municipalities build sustainability and environmental protection into planning and development (EMA Canada Inc., 2008). The province has introduced an amendment to the Planning Act in 2007 and updated the Provincial Policy Statement in 2005 in support of sustainability. It has also introduced new legislation to manage growth and protect natural resources (Government of Ontario, 2005a, 2005b, 2005c, 2008a, 2008b; Ministry of Municipal Affairs and Housing, $2005,2007)$ :

- Clean Water Act, 2005 - protects existing and future sources of drinking water.

- Greenbelt Act,2005 - allocates and utilizes natural resources in order to sustain and preserve Ontario's urban, rural, greenfield and agriculture lands.

- Places to Grow Act, 2005 -manages growth in a sustainable manner.

- Provincial Policy Statement, 2005 - contributed to efficient land-use planning and development.

- Amendment to Planning Act, 2007 - expanded the list of matters to include the promotion of development that is designed to be sustainable.

- Green Energy Act, 2008 -invests in renewable energy projects, increases conservation, and creates green jobs and economic growth.

- Lake Simcoe Protection Act, 2008 - protects and restores the ecological health of the Lake Simcoe watershed. 
Ontario's municipalities have been mandated to conform their Official Plans to the new and amended legislation listed above. Many municipalities, especially upper and single thers. have recently conformed to legislation issued before 2008. Currently, the upper tier government is working with their local municipalities to comply with the conformed Official Plans. The conformed Official Plans will be in line with most of the sustainability-related legislation listed above, but this research approach and focus is mainly on the Places to Grow Act's Greater Golden Horseshoe (GGH) growth plan. The growth plan for the GGH was prepared under the Places to Grow Act and is a framework to better manage growth in the GGH to 2031 and beyond. The Growth Plan's framework and objectives support the concept and systems that contribute to achieving sustainability. It guides decisions on transportation, infrastructure planning, land-use planning, housing and resource protection, which are considered the building blocks of sustainability (Roseland, 2005). The plan's guiding principle is that "communities will be supported by the pillars of a strong economy, clean and healthy environment and social equity" (Ministry of Public Infrastructure Renewal, 2006, 9).

\section{Government and Public Support of the Places to Grow Act}

\section{Government support.}

Plaming experience drawn from communities in the United Kingdom shows that the political will of local government is essential for a shift from business-as-usual to sustainable development (Urban Strategies Inc., 2005). According to Ontario's Growth Secretariat (K.

Ryan, personal communication, May 26,2010), the provincial government has made a number of infrastructure investment programs, many of which support growth planning in the GGH. Since 2003, the Province of Ontario has invested approximately $\$ 25.2$ billion in infrastructure in the GGH. These investment programs are: 
- Building Canada Fund - Communities Component, which has approximately a \$600million budget. As of June 2009, financial support was distributed across ten sectors, all of which have the potential to contribute to sustainability. The largest amounts were allocated to projects for recreation infrastructure, water and wastewater infrastructure, and local roads, each project receiving approximately $\$ 100$ million. The smallest amounts were allocated to regional and local airports, and solid waste management, each receiving less than $\$ 70,000$ (Ministry of Energy and Infrastructure, 2010a).

- The Infrastructure Stimulus Fund is a $\$ 4$-billion fund available for two years focusing on short-term objectives for economic stimulus. As of June 2009, financial support was distributed across 12 sectors, all of which have the potential to impact sustainable development. The largest amounts were allocated to projects for local roads, water and wastewater infrastructure, and municipal buildings, which received over $\$ 350$ million each, and the smallest amount was allocated to Brownfield redevelopment, which received $\$ 1.3$ million (Ministry of Energy and Infrastructure, 2009a).

- The Recreational Infrastructure Canada program supports the renewal and upgrading of recreational facilities in communities. An estimated $\$ 380$ million is dedicated to recreational projects (Ministry of Energy and Infrastructure, 2009b).

- The Knowledge Infrastructure Program supports college and university infrastructure projects with $\$ 2$ billion over a period of two years, (Ministry of Energy and Infrastructure, 2009c).

- ReNew Ontario supported the GGH Growth Plan with a five-year, \$30-billion plan to revitalize infrastructure throughout Ontario (Ontario Growth Secretariat, K. Ryan, personal communication, May 26, 2010). Based on ReNew progress reports, the government allocated billions to GGH by funding health care, public transit, 
highways, water and wastewater infrastructure, and affordable housing (Ministry of Energy and Infrastructure, 2006, 2007),

- Metrolinx, which was created in 2008, is the province's regional transportation agency for the Greater Toronto and Hamilton Area, and has a mission "to champion, develop and implement an integrated transportation system for our region that enhances prosperity, sustainability and quality of life" (Metrolinx, 2010a). "The Big Move" is Metrolinx's current regional transportation plan, which focuses on public and active transportation, and estimates transit capital costs to be $\$ 50$ billion over a period of 25 years (Metrolinx, 2010a).

Given the programs supporting the Places to Grow Act, the government's financial support appears to be strong, but time will tell whether Ontario's budgets will allot the money needed to make the infrastructure and transportation modifications required to move the GGH towards sustainable development. The programs show promise of a strong financial support for recreation, water and wastewater infrastructure, and local roads, all of which receive strong financial contribution from the Building Canada Fund, Infrastructure Stimulus Fund, Recreational Infrastructure Canada and ReNew Ontario (Ministry of Energy and Infrastructure, 2006, 2007, 2009a, 2009b, 2010a).

The public does have concerns over how the programs and recent Ontario budgets allotted the money, and it appears the government is prioritizing roads over transit (Anonymous, 2010, April 30). The first concern is that local roads still receive substantial financial support from the government - Building Canada Fund, Infrastructure Stimulus Fund and ReNew Ontario programs allotted large sums of money for road repairs, expansions and extensions. The second concern stems from the 2010 provincial budget announcement that delays the $\$ 4$ billion allotted to transit projects. The delay will impact some regions' 
rapid bus lane projects by two to three years (Fleischer, 2010, April 30) and other communities will be delayed in getting funding for a rapid-transit line (Nolan, 2010, April 8).

\section{Public support.}

For the most part, the public supports the activities associated with the Places to Grow Act. According to Wekerle et al. (2007), the new legislation, and especially the Places to Grow Act, Greenbelt Act and Lake Simcoe Protection Act, received extensive support from planners, environmentalists and the general public. In addition, many GGH residents do not welcome urban sprawl as they know it leads to traffic congestion and prevents communities from becoming pedestrian-oriented and sustainable (Rai, 2010, April 22), and they commend the Places to Grow Act for including urban design features such as bike paths to increase physical activity (Criscione, 2009, October 16). Some opposition to the Places to Grow Act exists in rural areas of the Greater Toronto Area. The forecasted population and employment growth numbers were not welcomed (Martin-Robins, 2007, December 21) and in some regions the plan is still to develop a significant number of single dwellings (Anonymous, 2010, June 7).

The government and public's support are crucial when making community changes that bring changes to the lifestyles of its residents, which is exactly what the Places to Grow $A c t$, with its plan for more compact communities and a stronger reliance on public transportation, is likely to do. When evaluating the extent to which sustainable policies are adopted in American cities, Jepson (2004) found that the key factors limiting progress towards sustainability included fiscal constraints, low public interest and a lack of knowledge. It has been almost five years since the Places to Grow Act was passed and the overall support for it appears to be strong. Up to now, Ontario municipalities have conformed their Official Plans to the Places to Grow Act and are beginning to implement sustainability- 
focused policies. Many municipalities are still waiting for the province to approve their Official Plans-many have received approvals from their municipal councils but in order to be in full conformance provincial approval is required (Government of Ontario, 1990, 2005c). The province's approval of the Official Plans will ensure that the municipalities" plans conform with the Places to Grow Act and other provincial legislation that supports sustainability and environmental protection, such as the Greenbelt Act.

However, it's worth asking what kind of tools are used to ensure that the conformed Official Plans will move Ontario's communities towards sustainability. Ontario's goal of moving towards sustainability is specified in many provincial laws, including the Places to Grow Act and Planning Act (Government of Ontario, 1990a, 2005c). Currently, municipal Official Plans are mandated to be reviewed and updated every five years to ensure conformity with provincial legislation and that they continue to address local priorities and changing community needs (Government of Ontario, 1990a). Is the five-year time period ideal to assess progress towards sustainability?

The task of measuring progress towards sustainability is a daunting one, as NRTEE (2004) found when it launched an initiative to measure Canada's progress towards sustainability. It is challenging because there is no simple way to model and predict the interaction of individuals, societies and natural systems (Abolina and Zilans, 2002; Dale, 2001; NRTEE, 2004). Measuring progress towards sustainability or performing an ex post evaluation of sustainability can offer a snapshot of the community's state of sustainability (NRTEE, 2004), but the question of when to measure progress is greatly complicated by the existence of social and natural processes that function on different time scales, that is, by "... the disparity between the time horizon of individual human decisions and that of the natural processes affected by these decisions" (Robinson and Legge, 1990, 40). For example, climate changes that can be unambiguously linked to anthropogenic greenhouse gases (GHG) may have a lag 
time of many decades before becoming visible (Hempel, 1996). In order to move towards sustainability, communities need to take quicker actions (Robinson, 2006 cited in Bulkeley, 2006). One way of knowing that sustainability-focused actions are being taken is by assessing them at the time community and policy decisions are made. Past sustainable-related projects have later shown to be unsustainable for several reasons, including that the projects aims were achieved but became unsustainable later on or that the project aims were unsustainable by design (Pediaditi et al., 2006).

The complexity of social and natural processes with much different time scales makes it difficult to know when to assess or measure progress on the issue of sustainability. This leaves the community at risk of missing opportunities if regional policies are only reviewed every five years. The Regional Official Plans are intended to conform with the Places to Grow Act. They are approved by their respective regional councils but await a response from the province. The local Official Plans are being brought into conformity to the goals and direction of the regions. The Official Plans at both the regional and local levels are still in draft form, therefore there are still opportunities to make policy changes which will further move communities towards achieving sustainability. The pending status of the Official Plans means the research findings and recommendations in this paper have the potential to inform and impact current planning policies. As the next review of planning policies will take place five years from now, this research, which is informed by previous sustainability studies and a literature review of frameworks to measure sustainability, will provide insight into whether Ontario's regions have laid a foundation to move towards achieving sustainable development. 


\section{Chapter 2: Methodology}

As mentioned earlier, the complexity associated with sustainability makes it challenging to make an assessment based on precise models (Abolina and Zilans, 2002), therefore a probing and holistic approach is needed to examine whether GGH municipalities are moving towards sustainability, which will involve an exploratory qualitative content analysis (Leech and Onwuegbuzie, 2007; Riffle et al., 2005; Rihoux, 2006; Woodrum, 1984). Previous studies of sustainability plans (Abolina and Zilans, 2002; Berke and Manta Conroy, 2000; Conroy, 2006: Jepson, 2004; Parkinson and Roseland, 2002; Portney, 2002; Saha and Paterson, 2008; Tsenkova and Damiani, 2009), which this research is founded on and derived from, concentrated on evaluating the presence of sustainability in urban areas in developed countries and on evaluations of communities, mainly in the United States and Canada, where sustainability-focused polices have been in place for a number of years. This research explores community policies in further detail to assess whether regional government in GGH has laid a foundation for achieving sustainability in how it expressed its long-range planning goals and policies in the Regional Official Plan. As mentioned earlier, the Official Plans are guided by the provincial Planning Act, which requires Ontario's municipalities to provide for a land-use planning system led by provincial policies (Government of Ontario, 1990a). The Regional Official Plans reviewed during this research are intended to conform to the Places to Grow Act-they are approved by their respective regional councils but await a response from the province.

The provincial-municipal relationship ensures that each region is subject to the same provincial land-use framework, which contributes to establishing a reliable comparative method by focusing on carefully matched cases that are similar to one another. Focusing on 
comparable cases is recommended in a comparative method with a small-N (Collier, 1991)the comparative methodology will be explained later on in this chapter.

The working definition defined earlier provides a basis for deriving this study's approach which consists of a sustainability framework and three levels of analysis. The first level of analysis assesses policies in Regional Official Plans in comparison to policy areas that forward sustainability principles. It will determine the presence of sustainably-focused policies within the regions and obtain a holistic view of the regional policies. The first level of analysis provides a basis for determining whether the sustainability focused policies have laid a foundation for the regions to move towards sustainability. The second level of analysis uses an environmental policy integration framework to assess whether regional policies integrate sustainability imperatives or take a piecemeal approach towards sustainability. The third level of analysis compares regions that exhibit comparable and favourable characteristics of sustainability. The objective is to learn the strengths and weaknesses in these regions" efforts to achieve sustainability.

The three levels of analysis will examine whether the regions have laid a foundation towards achieving sustainability. Previous sustainability studies found that the presence of sustainable activities in a community is a piecemeal indicator of sustainability but not necessarily an indicator that the community is moving towards sustainability (Tsenkova and Damiani, 2009). The level one analysis will determine the presence of sustainable activities within the regions while the second level of analysis will determine whether these activities are integrated. The policy integration framework helps assess which imperatives of sustainability are integrated and to what extent (Runhaar et al., 2008). According to Lafferty and Hovden (2003), one of the key defining features of sustainable development is the importance of integrating sustainability elements with one another and into other policy 
sectors to ensure they are mutually supportive. The integration of sustainability

environmental, economic and social elements is necessary, as sustainability cannot advance without making progress in all three imperatives simultaneously (Hempel, 1996; WCED, 1987). The third level of analysis examines comparable cases with community characteristics that are considered favourable (Portney, 2002) to achieving sustainability. The objective of the third level of analysis is to leam about the unique actions these communities take that can impact (positively or negatively) their move towards sustainability which have not been captured by the previous levels of analyses. The objective of performing a detail review is to obtain a holistic view of each policy area, each sustainability imperative and each case studied. The decision to perform a detailed review was derived from Hodge's (1997) set of principles that serve as criteria to determine progress towards sustainability. Hodge's (1997) principles are based on a review of 29 conceptual models that address the human-ecosystem relationships. Hodge (1997) indicated the importance of measuring progress towards sustainability by looking at different factors and variables that exist within a humanecosystem relationship, including assessment of space, time horizon, components of the ecosystem, uncertainty, anticipation, imposed stress and equity. The decision to capture regional policies that both support and oppose specific policy areas, along with the type of sustainable activities that are driven by regional policies, and incorporating Berke and Manta Conroy's (2000) methodology, stems from Hodge's principles of measuring towards sustainability. Berke and Manta Conroy's (2000) methodology of evaluating the extent to which plans promote sustainable development considers whether the policy was "suggested" or "required," with suggested policies receiving a lower score than required policies in promoting sustainable development. A higher score represents a higher level of community commitment in achieving sustainability. 
The sustainability framework and the three levels of analysis create a tool to examine whether sustainably focused regional policies have laid a foundation towards achieving sustainability. The research's focus is on the contributions that the tool makes towards determining whether the regions are moving towards sustainability. The methodology for the first level of analysis is discussed in the Presence of Sustainable Activities Analysis section, the second level of analysis is discussed in the Policy Integration Analysis section and the third level of analysis is described in the Regional Comparative Analysis section.

\section{Presence of Sustainable Activities Analysis}

The presence of sustainably focused activities is established by identifying regional policies with the policy areas that forward sustainability principles. The objective of the first level of analysis is to understand the policy details associated with each policy area in the sustainability framework. The results from this level of analysis do not indicate whether regional policies are moving towards sustainability but it provides a basis for determining whether the sustainability focused policies have laid a foundation for the regions to move towards sustainability using the exploratory methodologies in the second and third levels of analyses.

A holistic view is obtained in the first level by performing a detail review of all the policies in the Regional Official Plans using a coding research protocol. First, regional policies are examined to determine which of them share the characteristics of policy areas that forward sustainability principle (see Table 1 for the list of policy areas that forward sustainability principle and which form a sustainability framework). Each policy in the Regional Official Plan is assigned a policy area from the sustainability framework. The policy area description is matched with the direction and the description of the regional policy. If a regional policy shows signs of either supporting the policy area or not supporting the policy area, it is 
captured. For example, policies that focus on establishing boundaries around urban growth areas and policies that focus on expanding urban growth boundaries are both captured under the Urban Growth Boundary policy area. This ensures that the coded regional policies give a holistic view of the policy area in the sustainability framework. If a regional policy does not meet any of the policy areas in the framework, it is assigned a code that denotes it as not applicable. The coding analysis found a number of regional policies that represented multiple policy areas in a single regional policy; for example, smart development provisions and transport demand management initiatives were found to be located in a single regional policy in the Regional Official Plan, and these regional policies have multiple policy areas assigned to them from the sustainability framework.

The first level of analysis establishes whether sustainable activities are taking place within the regions and provides the data needed to perform the second and third level of analysis. The presence of sustainable activities is determined by the policy areas found in the regions. The analysis assumes that each policy area is equally important in contributing to sustainability, and though this is a shortcoming, as each policy area might not contribute equally, this approach was used in previous sustainability studies (Portney, 2002). The research's literature review found no consistent way of weighting sustainable measures in their overall contribution towards achieving sustainability (Abolina and Zilans, 2002; Berke and Manta Conroy, 2000; Conroy, 2006; Jepson, 2004; Parkinson and Roseland, 2002; Portney, 2002; Saha and Paterson, 2008; Tsenkova and Damiani, 2009). The main focus of this research is to select policy areas that address unsustainable practices in the GGH and align the policy areas to the scope of the Regional Official Plans, which is further explained in the Sustainability Framework section.

As the first level of analysis was based on the researcher's inference of the regional policies content, which was informed by a literature review of sustainability studies and 
frameworks, and by a content analysis method (Leech and Onwuegbuzie, 2007; Riffle et al., 2005; Rihoux, 2006; Woodrum, 1984), the researcher performed a reliability test to ensure that the coded data in the first level of analysis was trustworthy. The reliability method and results are described in Chapter 2 in the Reliability section.

\section{The Sustainability Framework}

This research project uses sustainable strategies, theories, principles, previous sustainability studies, and unsustainable practices in urbanized regions in a developed country to inform the development of a sustainability framework (Berke and Manta Conroy, 2000; Chakrabarty, 2001; Conroy, 2006; Dale, 2001; Hempel, 1996; Hodge, 1997; Hofmann, 2000; Jepson, 2004; Parkinson and Roseland, 2002; Pierce and Dale, 1999; Portney, 2002; Robinson, 2006; Robinson, 2008; Robinson and Legge, 1990; Saha and Paterson, 2008; Schor and Taylor, 2003; Tarasofsky, 2006; United Nations Department of Economic and Social Affairs Division of Sustainable Development, 2009). The framework is applied to Regional Official Plan policies in order to assess the regions' policies and whether they have laid a foundation towards becoming more sustainable. This research selected 20 policy areas from the literature review, which form a sustainability framework (see Table 1 for the list of policy areas in the sustainability framework). The policy areas that were selected consider the division of responsibilities that exists between the provincial, regional and municipal governments to ensure that only policy strategies that the regional and municipal govemments can lead on or substantially contribute to were selected (Table 1 identifies the governmental division of responsibility by policy area). The framework's policies also concentrate on land-planning strategies in order to align with the scope of the Regional Official Plan. A Regional Official Plan houses municipal council's policies on how land should be used in a community (Government of Ontario, 1990a). 
The sustainability framework consists of ten policy areas that support human and

nonhuman environment. It consists of five policies that support sustainable economic development and five policies that support sustainable social development.

Table 1: Sustainability Framework

\begin{tabular}{|c|c|c|}
\hline Policy Areas & Source & $\begin{array}{c}\text { Government } \\
\text { Responsibilities } \\
\end{array}$ \\
\hline \multicolumn{3}{|l|}{ Economic Sustainability } \\
\hline $\begin{array}{l}\text { Urban growth boundary - policies } \\
\text { establishing lines around a } \\
\text { community/region and the application of } \\
\text { zoning regulations that restrict urban } \\
\text { development to the areas inside the line }\end{array}$ & $\begin{array}{l}\text { Jepson, 2004; } \\
\text { Saha and } \\
\text { Paterson, } 2008\end{array}$ & $\begin{array}{l}\text { Provincial, under natural } \\
\text { resources and } \\
\text { environment } \\
\text { - Regional, under strategic } \\
\text { land-use planning } \\
\text { - Municipal, under local } \\
\text { planning and development }\end{array}$ \\
\hline $\begin{array}{l}\text { Smart development - zoning provisions that } \\
\text { permit integrated development projects } \\
\text { characterized by mixed uses, high densities, } \\
\text { centralized common areas, distributed and } \\
\text { accessible open space, health care and } \\
\text { recreational facilities, and an integrated } \\
\text { system of walkways and bikeways }\end{array}$ & $\begin{array}{l}\text { Conroy, 2006; } \\
\text { Jepson, 2004 }\end{array}$ & $\begin{array}{l}\text { Provincial, under natural } \\
\text { resources and } \\
\text { environment } \\
\text { - Regional, under strategic } \\
\text { land-use planning } \\
\text { - Municipal, under local } \\
\text { planning and development }\end{array}$ \\
\hline $\begin{array}{l}\text { Eco-industrial parks - policies to manage } \\
\text { development by defining eco-industrial } \\
\text { parks and policies that set aside "land for } \\
\text { development and sale to companies that } \\
\text { collaborate to enhance their economic } \\
\text { performance through improved } \\
\text { environmental performance through the } \\
\text { conversion of wastes into valuable inputs, } \\
\text { the cogeneration of energy, and the minimize }\end{array}$ & $\begin{array}{l}\text { Jepson, 2004; } \\
\text { Portney, 2002; } \\
\text { Saha and } \\
\text { Paterson, } 2008\end{array}$ & $\begin{array}{l}\text { Regional, under strategic } \\
\text { land-use planning; } \\
\text { development approvals } \\
\text { Municipal, under local } \\
\text { planning and development }\end{array}$ \\
\hline $\begin{array}{l}\text { Density and intensification targets - policies } \\
\text { establishing minimum density target } \\
\text { requirements for industrial, commercial and } \\
\text { residential zones }\end{array}$ & $\begin{array}{l}\text { Berke and Manta } \\
\text { Conroy, } 2000\end{array}$ & $\begin{array}{l}\text { Provincial, under natural } \\
\text { resources and } \\
\text { environment; property } \\
\text { rights } \\
\text { - Regronal, under strategic } \\
\text { land-use planning } \\
\text { Municipal, under local } \\
\text { planning and development }\end{array}$ \\
\hline $\begin{array}{l}\text { Purchase of development rights - policy } \\
\text { allowing the municipality to purchase } \\
\text { development rights or lands from } \\
\text { landowners for areas that have received }\end{array}$ & $\begin{array}{l}\text { Berke and } \\
\text { Conroy, 2000; } \\
\text { Jepson, 2004; } \\
\text { Saha and }\end{array}$ & $\begin{array}{l}\text { Municipal, under local } \\
\text { planning and } \\
\text { development; building } \\
\text { permits }\end{array}$ \\
\hline
\end{tabular}




\begin{tabular}{|c|c|c|}
\hline special conservation designation & Paterson, 2008 & $\begin{array}{l}\text { Regional, under strategic } \\
\text { land-use planning; } \\
\text { development approvals; } \\
\text { land division consent } \\
\text { applications }\end{array}$ \\
\hline \multicolumn{3}{|l|}{ Environmental Sustainability } \\
\hline $\begin{array}{l}\text { Identify and protect the environment - policy } \\
\text { establishing a systematic identification and } \\
\text { strategic protection of environmentally } \\
\text { sensitive and biologically significant open } \\
\text { spaces in the region and corridors to connect } \\
\text { them by prohibiting development in these } \\
\text { spaces }\end{array}$ & $\begin{array}{l}\text { Saha and } \\
\text { Paterson, } 2008\end{array}$ & Provincial \\
\hline $\begin{array}{l}\text { Urban forestry - policy requiring planting } \\
\text { and maintaining trees specifically to reduce } \\
\text { carbon emissions }\end{array}$ & Jepson, 2004 & $\begin{array}{l}\text { Regional, under } \\
\text { Municipal government }\end{array}$ \\
\hline $\begin{array}{l}\text { Energy conservation - policies to conserve } \\
\text { energy and use alternative energy systems } \\
\text { (e.g., renewable energy like solar, wind, } \\
\text { biogas, etc.) }\end{array}$ & $\begin{array}{l}\text { Conroy, 2006; } \\
\text { Jepson, 2004; } \\
\text { Parkinson and } \\
\text { Roseland, 2000; } \\
\text { Portney, 2002; } \\
\text { Saha and } \\
\text { Paterson, 2008 }\end{array}$ & $\begin{array}{l}\text { Green building program } \\
\text { would be a municipal } \\
\text { responsibility, not regional }\end{array}$ \\
\hline $\begin{array}{l}\text { Water source protection and water } \\
\text { conservation - policies to protect, manage } \\
\text { and conserve water sources and use }\end{array}$ & $\begin{array}{l}\text { Conroy, 2006; } \\
\text { Parkinson and } \\
\text { Roseland, 2000; } \\
\text { Portney, 2002; } \\
\text { Saha and } \\
\text { Paterson, 2008 }\end{array}$ & $\begin{array}{l}\text { Regional, under municipal } \\
\text { water supply and sanitary } \\
\text { sewerage systems; water and } \\
\text { sewer billing }\end{array}$ \\
\hline $\begin{array}{l}\text { Green procurement - municipal contracts } \\
\text { that include requirements that vendors take } \\
\text { back packaging and unused materials and } \\
\text { products, and that specify environmentally } \\
\text { responsible management practices. }\end{array}$ & $\begin{array}{l}\text { Conroy, 2006; } \\
\text { Saha and } \\
\text { Paterson, } 2008\end{array}$ & $\begin{array}{l}\text { Regional and municipal } \\
\text { governments }\end{array}$ \\
\hline $\begin{array}{l}\text { Integrated waste management - policies on } \\
\text { reducing waste through integrated waste } \\
\text { management }\end{array}$ & $\begin{array}{l}\text { Conroy, 2006; } \\
\text { Parkinson and } \\
\text { Roseland, 2000; } \\
\text { Portney, 2002; } \\
\text { Saha and } \\
\text { Paterson, } 2008\end{array}$ & $\begin{array}{l}\text { Regional, under solid waste } \\
\text { management, diversion, } \\
\text { recycling, composting, } \\
\text { processing and disposal; } \\
\text { promotion and education of } \\
\text { waste management; regional } \\
\text { waste disposal sites and } \\
\text { household hazardous waste } \\
\text { depots }\end{array}$ \\
\hline $\begin{array}{l}\text { Transportation demand management - policy } \\
\text { encouraging the reduction of automobile use } \\
\text { through the application of traffic control, } \\
\text { public parking and public transit and road }\end{array}$ & $\begin{array}{l}\text { Conroy, 2006; } \\
\text { Saha and } \\
\text { Paterson, } 2008\end{array}$ & $\begin{array}{l}\text { Regional under transit and } \\
\text { specialized transit } \\
\text { services; regional roads, } \\
\text { bridges and traffic signals }\end{array}$ \\
\hline
\end{tabular}




\begin{tabular}{|c|c|c|}
\hline strategies & & $\begin{array}{l}\text { Municipal under parking } \\
\text { and bylaw enforcement }\end{array}$ \\
\hline $\begin{array}{l}\text { Pedestrian access plan - policies with an } \\
\text { integrated plan for walkways for the purpose } \\
\text { of improving pedestrian safety and access to } \\
\text { local places of employment, home and } \\
\text { leisure, and that are incorporated with the } \\
\text { transit support development and transit } \\
\text { demand management }\end{array}$ & Conroy, 2006 & $\begin{array}{l}\text { Municipal, under local streets } \\
\text { and sidewalks }\end{array}$ \\
\hline $\begin{array}{l}\text { Bicycle access plan-policies with an } \\
\text { integrated plan of bicycle trails, bike lanes } \\
\text { and road crossings, and that are incorporated } \\
\text { with the transit support development and } \\
\text { transit demand management }\end{array}$ & Jepson, 2004 & $\begin{array}{l}\text { Municipal, under local streets } \\
\text { and sidewalks }\end{array}$ \\
\hline $\begin{array}{l}\text { Public education of unsustainable practices } \\
\text { and the environment - public awareness and } \\
\text { education of the impact GGH consumption } \\
\text { patterns has on the environment and lives of } \\
\text { those in distant lands. }\end{array}$ & $\begin{array}{l}\text { Saha and } \\
\text { Paterson, } 2008\end{array}$ & All levels of government \\
\hline \multicolumn{3}{|l|}{ Social Sustainability } \\
\hline $\begin{array}{l}\text { Affordable transit access - policies } \\
\text { subsidizing the cost of public transportation } \\
\text { to help residents in low income. }\end{array}$ & $\begin{array}{l}\text { Saha and } \\
\text { Paterson, } 2008\end{array}$ & $\begin{array}{l}\text { Regional, under transit and } \\
\text { specialized transit services }\end{array}$ \\
\hline $\begin{array}{l}\text { Cooperative housing - land-use provisions } \\
\text { that permit multi-family housing } \\
\text { development in which residents have both } \\
\text { private and shared spaces under cooperative } \\
\text { ownership and management }\end{array}$ & Jepson, 2004 & $\begin{array}{l}\text { Regional, under strategic } \\
\text { land-use planning } \\
\text { Municipal, under local } \\
\text { planning and development }\end{array}$ \\
\hline $\begin{array}{l}\text { Affordable housing - zoning regulations that } \\
\text { encourage or require the provision of lower } \\
\text { cost housing. }\end{array}$ & $\begin{array}{l}\text { Conroy, 2006; } \\
\text { Saha and } \\
\text { Paterson, } 2008\end{array}$ & $\begin{array}{l}\text { Regional, under social } \\
\text { housing }\end{array}$ \\
\hline $\begin{array}{l}\text { Adaptive and mitigative policies to protect } \\
\text { urban communities from climate change }\end{array}$ & $\begin{array}{l}\text { Dale, 2001; } \\
\text { Roseland, } 2005 \\
\end{array}$ & $\begin{array}{l}\text { Regional, under emergency } \\
\text { management }\end{array}$ \\
\hline $\begin{array}{l}\text { Civic engagement - individual and collective } \\
\text { actions designed to identify and address } \\
\text { issues of public concern }\end{array}$ & $\begin{array}{l}\text { Conroy, 2006; } \\
\text { Portney, 2002 }\end{array}$ & All levels of government \\
\hline
\end{tabular}

Policy area selection was also based on sustainability issues experienced in an urban area in a

developed country. As mentioned earlier, environmental degradation is wide-spread in

industrialized countries (Boyd and Suzuki, 2008), and with Canada's high gross domestic 
product (GDP), which indicates a relatively high standard of living (Human Resources and Skills Development Canada, 2010) - these are the main reasons for choosing a framework that predominantly consists of policy areas that contribute to environmental sustainability. Based on a literature review, this research views sustainability as a dynamic state that balances the three imperatives of sustainability (Berke and Manta Conroy, 2000), and the presence of a higher number of environmentally sustainable policy areas will shift the focus to environmental protection and provide an opportunity to balance GGH's environmental objectives with its strong economic and social systems.

Previous sustainability studies based their analyses on a larger number of policy areas than this research: Saha and Paterson (2008) had thirty-six policy areas while Portney (2002) has thirty-four. This research's policy areas were restricted by the legislation and governmental responsibilities as discussed earlier. Without any restrictions, policy areas of Brownfield redevelopment, agriculture protect zoning, right to farm legislation and tax shift from labor and income to resource consumption would provide a more comprehensive policy analysis of communities' contributions towards achieving sustainability (Conroy, 2006; Jepson, 2004; Portney, 2002; Saha and Paterson, 2008; Schor and Taylor, 2003).

\section{Policy Integration Analysis}

The second level of analysis is derived from an environmental policy integration (EPI) framework developed by Runhaar et al. (2008). A policy integration framework like the EPI is a tool that helps recognize whether policy integration exists between policies in different sustainability pillars, for example, whether policies under economic development are integrated with environmental protection policies. In addition, a policy integration framework is used to determine whether policies are mutually supportive in helping achieve sustainability as well as providing insight into what elements of sustainability are integrated 
and to what degree--that is, it determines if elements are integrated but not on equal terms. integrated on equal terms, or one element is prioritized over another (Lafferty and Hovden, 2003; Runhaar et al., 2009). According to Lafferty and Hovden (2003), one of the key defining features of sustainable development is the emphasis on the integration of the sustainability elements with each other and with other policy sectors. Lafferty and Hovden (2003) and Runhaar et al. (2009) focus on integrating environmental objectives into nonenvironmental policy sectors, which aligns to the higher presence of policy areas in the sustainability framework that focus on environmental sustainability.

There are three integration forms within the EPI framework: coordination, harmonization and prioritization.

The EPI forms are expanded in this research to consider social and economic integration, as EPI focuses on environmental integration into non-environmental policy sectors (Runhaar et al., 2009). The three modified forms of integration are:

1. Coordination, which integrates more than one imperative of sustainability, though they are not integrated on equal terms. For example, environmental and economic elements are integrated but environmental objectives are compromised by economic development. This form is considered limited in its integration abilities (Runhaar et al., 2009).

2. Harmonization, which is an attempt to put all of the imperatives of sustainability on equal terms. Examples include mixing spatial functions in order to minimize car movements or influencing public choices of transport by situating public transport close by and so that residents with different financial and social needs have easy access (Runhaar et al, 2009).

3. Prioritization, which favours one of the three imperatives of sustainability over the other two. For example, reserving areas for nature or smart growth to safeguard 
against urbanization. The precautionary principle, which is based on preventing the emergence of sources of environmental degradation, is also considered a prioritization form of integration (Runhaar et al., 2009).

This research applies the three forms to regional policies in order to assess the level of integration exhibited by the regional policies. The regional policies for each policy area identified during the first level of analysis are reviewed to determine the integration form or forms the policies exhibit. As in the first level of analysis, the researcher's inference of the regional policies content determines the integration form or forms associated with each policy area. Due to the small number of policy areas in the sustainability framework a reliability test to determine whether the integration form or forms that was associated to the policy area due to chance or error was not performed.

\section{Regional Comparative Analysis}

The third level is a comparative policy analysis to examine the differences in policies between comparable regional governments that can impact the progress towards achieving sustainability. It provides insight into the policy tools used to achieve the same objective as well as revealing the strengths and weaknesses that each municipality brings towards achieving sustainability. Case similarities are discussed in detail in the next section. The objective of the regional comparative analysis is to learn about policy directives from sustainably advanced communities that support sustainable development and exhibit characteristics of taking sustainability seriously. The last level of analysis will examine whether any additional directions exist in the regional policies that were not identified in the previous levels of analyses, but can contribute (positively and negatively) towards sustainability. 


\section{Case selection.}

A small number of cases were selected for this research due to the detailed nature of the analysis. Qualitative comparative analysis supports the small-N approach and the need to consider each individual case as a complex entity that should be comprehended as a whole (Rihoux, 2006). Comparative analysis usually evaluates between two and ten cases (Collier, 1991); this study has two cases. Lijphart suggests that where there are few cases, the cases selected should be comparable (as cited in Collier, 1991). This study focuses on cases with similar political and environmental context as well as similar community characteristics, which were found to contribute to how seriously a community undertakes sustainability efforts (Portney, 2002). In his study of 25 American cities pursuing sustainability, Portney: (2002) concluded that cities with a higher than average number of citizens less than 18 years, a low presence of manufacturing services, a higher median age of residents, and communities with a higher percentage of high school graduates are likely to take sustainability more seriously (Portney, 2002). Table 2 provides regional profile and characteristics identified by Portney (2002) of the two cases selected: York and Peel. The regions of York and Peel were also selected because of their similarities when it comes to the proximity to each other and to the largest city in Ontario, Toronto (see Appendix B for the map of York and Peel regions, and their location within the GGH and proximity to the city of Toronto) (Ministry of Public

- Infrastructure Renewal, 2006; Region of Pcel, 2009; Region of York, 2009, Statistics Canada, 2009). 
Table 2: Regional Profile (Region of Peel, 2009; Region of York, 2009; Statistics Canada, 2006)

\begin{tabular}{|l|c|c|}
\hline Based on the 2006 Census & Peel Region & York Region \\
\hline Population & $1,159,405$ & 892,712 \\
\hline Forecasted population in 2031 & $1,645,000$ & $1,507,500$ \\
\hline Land area (square km) & 1242.40 & 1761.84 \\
\hline Population density per square km & 933.2 & 506.7 \\
\hline Industry services: Business and other services & $41.5 \%$ & $35.6 \%$ \\
\hline Industry services: Manufacturing services & $17 \%$ & $13 \%$ \\
\hline Median age & 35.6 & 37.5 \\
\hline Percentage of population $\geq 15$ years old & $79 \%$ & $80 \%$ \\
\hline Percentage of population $\geq 20$ years old & $71 \%$ & $72 \%$ \\
\hline $\begin{array}{l}\text { Percentage of population with at least a high } \\
\text { school education }\end{array}$ & $80 \%$ & $81 \%$ \\
\hline
\end{tabular}

In addition, both regions used a similar review planning process when conforming their Regional Official Plans to the Places to Grow Act. The process of community planning to review the recent Regional Official Plans was viewed through a lens of sustainability. Each region has its own sustainability framework. For Peel, "[t]he over-arching theme of ... [Peel's Regional Official] Plan is sustainability which refers to meeting the needs of the present without compromising the ability of future generations to meet their own needs. Regional Council will work towards sustainability by applying a sustainable development framework, which will provide a holistic approach to planning, action and measurement"' (Region of Peel, $2009,5)$, where a "... sustainable development framework enables integration of the environmental, social, economic and cultural imperatives throughout the Plan" (Region of Peel, 2009, 6). York's Regional Official Plan, meanwhile, states that "[s]ustainability is the lens through which York Region formulates, enhances and implements policy. The awardwinning York Region Sustainability Strategy: Towards a Sustainable Region provides a long term framework for making smarter decisions about all municipal responsibilities that fully evaluates economic, environmental and community considerations" (Region of York, 2009, 1). 
Lastly, the reason for regional level comparison is that only single and upper-tier governments were supposed to conform their Official Plans to the Places to Grow Act by the provincial deadline of June 2009 (K. Ryan, personal communication, December 18, 2008). This research concentrates on the Places to Grow Act as the framework, and objectives of the Places to Grow Act support the concept and systems that contribute to achieving sustainability (Ministry of Public Infrastructure Renewal, 2006).

\section{Reliability.}

To ensure the coded data are reliable and trustworthy, the researcher repeated the coding protocol applied in the first level of analysis. Riffle et al. (2005) indicate that the most appropriate reliability test for a single coder is to measure the coding differences at two points in time. The first coding session took place between May 15 and May 22, 2010, and the second coding session took place on June 22 and 23,2010 . Since inter-coder reliability is the most recommended approach (Berke and Manta Conroy, 2000; Rime et al., 2005) as the chance of accidentally agreeing decreases as the number of coders increases, the researcher decided to take on a larger sample size to re-code than the $10 \%$ sample needed to achieve a $95 \%$ confidence level (Riffle et al., 2005). A large sample of $50 \%$ of the 1274 policies in the York and Peel's Regional Official Plans were re-coded to increase the accuracy of the data coded by a single coder. This research selected Scott's $\mathrm{Pi}$, which is one of the most frequently used reliability tests (Riffle et al, 2005). Scott's Pi corrects for chance agreement in reliability assessment by looking at the actual usage of every policy area in the sample and uses that distribution to calculate probability for chance agreement (Riffe et al, 2005). The observed agreement is determined at 0.89 while the expected agreement at 0.86 , which indicates an adequate reliability, as it is above 0.8 , though an expected agreement as low as 
0.667 could be acceptable for research that is complex and exploratory (Riffe et al., 2005 cited in Krippendorff, 2004).

Most of the disagreements were the result of assigning a single policy area to a regional policy that had multiple directives during the first coding session. The remaining small number of disagreements resulted from human error; during the first coding session, some regional policies were missed and no policy area was assigned until the second coding session. The results from the second coding analysis were used to perform the second and third level of analysis, that is, policy integration and regional comparative analysis. 


\section{Chapter 3: Analysis and Findings}

An exploratory analysis was undertaken to examine York and Peel's recently conformed Regional Official Plans in order to determine whether they are moving towards sustainability. The analysis consists of a sustainability framework designed to support an urban area in a developed country, and comprises three levels of analysis using a detailed comparative qualitative content analysis. The first level of analysis determines the presence of sustainable activities within the regions using the sustainability framework, and obtains a holistic view of the regional policies. The second level of analysis assesses whether regional policies integrate the sustainability imperatives or take a piecemeal approach to sustainability. The third level of analysis compares the regions of York and Peel's policy actions towards achieving sustainability.

This chapter discusses the analysis and findings for each policy area within the sustainability framework. The three pillars of the sustainability framework also organize the discussion, and they are economic sustainability, environmental sustainability and social sustainability. Table 3: The Presence of Sustainable Activities summarizes the findings from the first level of analysis by region and policy area.

The policy numbers predominantly from Peel and York's Regional Official Plans but also from the Places to Grow Act are referred to during the discussion in order to provide specific examples, and for the most part they are captured in brackets. Policy numbers identified in the analysis section are examples of policies that either support or oppose a specific policy area and do not represent a complete policy analysis (see Appendix C for Peel's detailed policy analysis and Appendix D for York's). 
The discussion of the analysis and findings attempts to provide insight into whether the regions are moving forward towards sustainability. As mentioned earlier, the regions are mandated to review their Official Plans every five years, thus opening themselves to the possibility of missing the opportunity to take appropriate policy actions in order to move towards sustainability. This research fills the five-year gap by providing an ex ante evaluation of whether the regions' have laid a foundation towards achieving sustainable development.

Table 3: Presence of Sustainable Activities

\begin{tabular}{|c|c|c|}
\hline Sustainable Policy Areas & Peel Region & York Region \\
\hline \multicolumn{3}{|l|}{ Economic Sustainability } \\
\hline 1. Urban growth boundary & $\bar{Y}$ & $\mathrm{Y}$ \\
\hline 2. Smart development & $\mathrm{Y}$ & $\mathrm{Y}$ \\
\hline 3. Eco-industrial park & $\mathrm{Y}$ & $N$ \\
\hline 4. Density targets & $\mathrm{Y}$ & $\mathrm{Y}$ \\
\hline 5. Purchase of development rights & $\mathrm{Y}$ & $\mathrm{Y}$ \\
\hline \multicolumn{3}{|l|}{ Environmental Sustainability } \\
\hline 6. Identify and protect environment & $\mathrm{Y}$ & $\bar{Y}$ \\
\hline 7. Urban forestry program & In development & In developmen \\
\hline 8. Energy conservation & $Y$ & $Y$ \\
\hline 9. Water conservation and water sources protection & $\mathrm{Y}$ & $\mathrm{Y}$ \\
\hline 10. Green procurement & $\mathrm{Y}$ & $\mathrm{Y}$ \\
\hline 11. Integrated waste management & $\mathrm{Y}$ & $\mathrm{Y}$ \\
\hline 12. Transportation demand management & $\mathrm{Y}$ & $\mathrm{Y}$ \\
\hline 13. Pedestrian access plan & In development & $\mathrm{Y}$ \\
\hline 14. Bicycle access plan & In development & $\mathrm{Y}$ \\
\hline 15. Public education on unsustainable practices & $\mathrm{Y}$ & $\mathrm{Y}$ \\
\hline \multicolumn{3}{|l|}{$\begin{array}{l}\text { Social Sustainability } \\
\end{array}$} \\
\hline 16. Affordable transit & $\mathrm{N}$ & $\mathrm{Y}$ \\
\hline 17. Cooperative housing & $\mathrm{Y}$ & $\mathrm{Y}$ \\
\hline 18. Affordable housing & $\mathrm{Y}$ & $\mathrm{Y}$ \\
\hline 19. Climate Change & $Y$ & $\mathrm{Y}$ \\
\hline 20. Civic engagement & $\mathrm{Y}$ & $\mathrm{Y}$ \\
\hline Total Count & 20 & 20 \\
\hline Total - Yes & 16 & 18 \\
\hline Total - No & 1 & 1 \\
\hline Total - In Development & 3 & 1 \\
\hline
\end{tabular}

"Y" signifies that the region has this policy area; "N" signifies that the region does not have this policy area; "In development" signifies that the region is in the process of developing policies for this policy area. 


\section{Policy Areas - Economic Sustainability}

The economic imperative in sustainability concentrates on financial growth and profit (ICLEI, IDRC and UNEP, 1996). The policy areas that were identified as supporting the economic imperative, when viewed through a lens of sustainability, concentrate on managing growth in a sustainable manner (Berke and Manta Conroy, 2000; Conroy, 2006; Jepson, 2004; Portney, 2002; Saha and Paterson, 2008). Sustainable growth is usually associated with the concept of smart growth, which directs the community to avoid urban sprawl by directing economic development and population growth in such a way as to reduce the impact on the natural environment (Portney, 2002). The five policy areas under the economic pillar of sustainability were selected because they address GGH issues of urban sprawl and growing population (Ministry of Public Infrastructure Renewal, 2006).

\section{Urban Growth Boundary}

The urban growth boundary policy area concentrates on policies that establish lines around communities in order to apply zoning regulations that restrict urban development to the areas inside the lines (Jepson, 2004; Saha and Paterson, 2008). This policy area has been designated as a smart growth policy under the economic development initiative in previous sustainability studies (Saha and Paterson, 2008). As mentioned earlier, smart growth contributes to sustainability as it allows the economy and population to grow by reducing the growth's impact on the environment (Portney, 2002).

The provincial government, which is responsible for natural resources and the environment, has defined urban areas in the Places to Grow Act's growth plan for the GGH as areas that will "accommodate a significant share of population and employment growth" (Ministry of Public Infrastructure Renewal, 2006, 16). The Places to Grow Act mandated that regional governments define urban boundaries in their Regional Official Plans and their 
municipalities' Local Official Plans, and direct a significant amount of growth inside the boundaries (Ministry of Public Infrastructure Renewal, 2006). Regional governments are responsible for strategic land-use planning in Ontario, and along with local municipalities who plan and develop communities, regional governments are in a position to define and implement the urban growth boundary policy area (Ministry of Municipal Affairs and Housing, 2010).

Both regions' Regional Official Plans have policies that establish boundaries to contain growth around urban and rural areas. For example, the region of Peel has established boundaries for built up areas, designated greenfield areas (5.5.3.2.1), employment lands within urban and rural areas (5.6.2.1) and core areas of the Greenland System (5.3.2.1). Within urban areas, lines were established around urban growth centres, intensification corridors, urban nodes, major transit station areas (5.5.3.2.5 and 5.5.3.2.6) and the urban system (5.3.2.1) (Region of Peel, 2009). Refer to the Glossary for the definitions of these areas, corridors, centres and nodes.

The regions direct a significant portion of growth within urban areas and limit the growth in rural areas. York's Regional Official Plan recognizes urban areas (6.2.2), regional centres and corridors $(5.4 .1,5.4 .19,5.4 .30)$, and local regional centres and corridors $(5.5 .1)$ as areas where the most intensive development will take place (Region of York, 2009), while limiting growth or prohibiting major developments in rural areas $(5.6 .22,5.6 .23,5.6 .24)$.

Expansion of established areas are permitted in both the Places to Grow Act and York and Peel's Regional Official Plans, though it is allowed only through a municipal comprehensive review or similar type of analysis. Policy 2.2 .8 in the growth plan for the GGH, and policies 5.2.2.3 in Peel and 5.1.1.2 in York, are examples of the policies that support urban growth boundary expansion. According to the Places to Grow Act, and York $(5.2 .2 .3,5.4 .4 .2 .2,5.5 .3 .2 .8,5.5 .4 .2 .4)$ and Peel's $(5.1 .12,5.4 .35)$ Regional Official Plans, a 
municipal comprehensive review or similar type of analysis needs to consider the long-term use of the expanded area, the impact of expansion on the region's intensification and density. targets, the protection of environmentally sensitive and significant lands, and the infrastructure available in the expanded area.

The fact that the province and regions allow these areas to be expanded shows sound planning and an unsustainable practice at the same time. It is a sound approach as there is always a level of uncertainty attached to any forecast in community planning (Region of York, 2010b; Hodge, 1997). Although York, Peel and the Places to Grow Act require a municipal comprehensive analysis that questions the expansion's impact on smart growth and significant environmental areas, the Places to Grow Act dictates that the boundaries can be expanded to include agricultural operations as long as the impact on the agricultural lands are mitigated (Ministry of Public Infrastructure Renewal, 2006). This approach exhibits characteristics of an integration form of coordination, which limits the integration of environmental objectives. Environmental objectives, in this case, are the protection of the natural environment from being lost to urban expansion and the community's ability to produce its own food. The impact on the GGH's agricultural operations should be minimal, as York makes up $1.7 \%$ and Peel makes up $0.84 \%$ of the total farms in Ontario (Ministry of Agriculture, Food and Rural, 2010). However, allowing such expansion supports unsustainable practices as it takes away from the community's self-reliance and puts local food security at risk, as well as contributing to further loss of lands due to human expansion. Society's long-term survival and a community's self-reliance is not dependent upon development but on the biological wealth and its ability to support human and nonhuman life (ICLEI, IDRC and UNEP, 1996; Dale, 2001). 
As municipalities have been working to comply with the Greenbelt Act and Places to Grow Act, it has been determined that less than $35 \%$ of the "whitebelt" will be needed for future development (Ontario Greenbelt Alliance, 2010). According to the Ontario Greenbelt Alliance (2010), the whitebelt is an unprotected area of prime foodland and green space, and the region of York views these lands as development opportunities and currently plans to develop on them (Region of York, 2010b). There are numerous debates regarding York's expansion into the whitebelt area, and time will tell what decision the government will make. However, the current policy and debate show signs of contradictions, which limits the community's ability to achieve sustainability.

The analysis found that the urban growth boundary policy area in the regions of York and Peel exhibit all three forms of integration. Coordination was discussed earlier, and the second integration form, prioritization, is evident in policies that reserve a particular area in order to direct growth inside of the area. These policies prioritize sustainable economic objectives, which the Greater Vancouver Regional District considers an effective tool to sustainably manage land (Urban Strategies Inc., 2005). The integration form of harmonization is also present, as both regions consider other sustainability-focused policy areas when establishing the boundary lines or managing the uses and growth inside them, such as smart development in York policy 4.4.4, and, density and intensification targets in Peel policy 5.5.3.2.4. In addition, York incorporates affordable housing and transport demand management policies when determining regional centres and corridors (5.4.12). This inclusion of other policy areas in the urban growth boundary policies can integrate economic, social and environmental objectives when planning a community to manage growth sustainably. 


\section{Smart Development}

The policy area of smart development provides official planning and zoning provisions that permit integrated development projects characterized by mixed uses, high densities, centralized common areas, distributed and easily accessible open spaces, health care and recreation facilities, and an integrated system of walkways, bikeways and transit (Jepson, 2004). The smart development policy area supports the urban growth boundary as it encourages building compact urban communities within the boundaries, and therefore aligns it with the smart growth concept (Jepson, 2004; Conroy, 2006; Portney, 2002). The Places to Grow Act's growth plan dictates that the GGH will consist of communities that are compact, complete and can meet people's daily needs (Ministry of Public Infrastructure Renewal, 2006). Ontario's regions have the ability and accountability to implement the smart development policy area, as they are responsible for strategic land-use planning, and their municipalities are responsible for local planning and development (Ministry of Municipal Affairs and Housing, 2010).

The Regional Official Plans in both communities have policies that satisfy most of the smart development provisions. York requires its municipalities to permit mixed uses and higher densities $(5.4 .15,5.4 .20)$ in its regional centres, and Peel requires the same in its urban growth centres (5.3.3.2.3). Both regions have provisions for common areas, open spaces and services that are easily accessible, which is a requirement in the smart development policy area (Peel 5.5.2.1; York 3.1.5, 5.4.6, 5.4.25, 5.6.15, 5.6.8). In addition, York policies 5.4.5 and 4.4.4, and Peel's 5.3.3.2.3 and 5.3.2.6, provide provisions to ensure that pedestrian and transit-oriented designs are incorporated into community designs. The region of Peel has no policies that support bike-oriented designs, while York supports bike-oriented designs in regional centres (5.4.5), local centres $(5.5 .3)$ and in retail-specific areas (4.4.1). 
The region of Peel encourages its local municipalities to incorporate policies in their Local Official Plan that will develop communities with a range and mix of employment and housing types, high-quality public open spaces and easy access to retail and services (5.5.2.1) Although York requires its local municipalities to include all smart development zoning provisions in the Local Official Plan, it also encourages secondary and subdivision plans within the designated greenfield area be developed with smart development provisions (5.2.16). Berke and Manta Conroy's (2000) methodology of evaluating the extent to which plans promote sustainable development consider whether the policy was "suggested" or "required." Suggested policies received a lower score than the required policies in promoting sustainable development. As the two regions were selected as case studies in order to control for political and environmental factors, there should be no difference in which polices are suggested and which are required other than a choice in their policy tools to implement Regional and Local Official Plans.

Lastly, both regions have considered smart development provisions in other policy areas, such as urban growth boundary, density and intensification targets, transport demand management and pedestrian access plans. Having mixed use and public spaces, for instance, in policy areas that are not primarily concerned with designating the use of space can make a community more sustainable, as it incorporates smart development in other community decisions. The regional policies exhibit harmonization integration, as they create urban designs that allow communities to adapt a more sustainable lifestyle. The policies show signs of treating environmental and economic objectives equally. As an example, an environmental objective can be to reduce GHG, which smart development provisions can achieve by reducing communities' reliance on vehicles by locating places of employment and residences in close proximity to transit. An economic objective can be for communities to continue to grow in a sustainable manner. 


\section{Eco-Industrial Parks}

An eco-industrial park is "[a] community of businesses that collaborate with each other and with the local community to efficiently share resources (information, materials, water, energy, infrastructure and natural habitat), leading to economic gains, gains in environmental quality, and equitable enhancement of human resources for the business and local community" (Lambert and Boons, 2001, 472). An eco-industrial park policy sets aside "land for development and sale to companies that collaborate to enhance their economic performance through improved environmental performance through the conversion of wastes into valuable inputs, the cogeneration of energy, and the minimize of material throughput" (Jepson, 2004, 239). Ontario regions and municipalities have the ability to contribute to designing eco-industrial parks, as they are responsible for strategic land use, land division consent application, water and wastewater services, solid waste management, and building inspection and design (Ministry of Municipal Affairs and Housing, 2010).

The Places to Grow Act's growth plan for the GGH and Regional Official Plans did not have any policies explicitly supporting this policy area. According to Ray Côté, a founding director at the Eco-Efficiency Centre at Dalhousie University in Halifax, "[m]unicipalities are just really scratching the surface in terms of requiring features that conserve resources and so on... If we wanted to, we could pass bylaws and identify guidelines to require developers to pay attention to those things, but it needs to start with the municipalities. And they still need educating" (Mitham, 2009,2). Although, eco-industrial park policies are not explicitly defined in Regional Official Plans, Clay Braziller, who manages business development and marketing for Eco-Industrial Solutions Ltd., a Vancouver-based company specializing in eco-industrial planning and development, believes they will be soon, as municipalities face restrictions on growth through legislations like the 
Places to Grow Act and Greenbelt Act (Mitham, 2009). The region of Peel and some of its local municipalities support the Partners in Project Green, a project planned for 27,500 acres surrounding Toronto Pearson International Airport. It is the largest eco-industrial project currently planned for Canada (GTAA Partners in Project Green, 2010; Mitham, 2009).

Since this research relies on the content of policies to perform an analysis, the absence of more descriptive policies regarding eco-industrial parks prevents the use of the coding protocol, EPI framework and comparative analysis.

\section{Purchase of Development Rights}

A number of sustainability studies consider this policy area, which allows municipalities to purchase development rights from landowners that reside on environmentally sensitive or significant lands, as one of the more significant policy directions to sustainable development (Berke and Manta Conroy, 2000; Jepson, 2004; Saha and Paterson 2008). The regions and local municipalities have the responsibility to strategically plan land use, process land division consent applications, and manage the planning and development of a community, and are able to contribute to this policy area (Ministry of Municipal Affairs and Housing, 2010). In addition, the regions are supported by provincial legislation that focuses on environmental protection and sustainable land management, such as the Greenbelt Act, Oak Ridges Moraine Act and Provincial Policy Statement (Government of Ontario 2001, 2005b; Ministry of Municipal Affairs and Housing, 2005).

Both York and Peel's Regional Official Plans have policies allowing the municipalities to purchase lands for areas that have received special conservation designation. York's purchase rights have a goal of protecting the regional Greenland System, which contains key natural heritage and hydrologic features, and the adjacent lands necessary to maintain these features (2.1.16). The region is not obligated to purchase these lands but the option is available 
(2.1.17). The region of Peel also allows the securement of natural areas but the purchasing of land is suggested as a last resort, with preference given to planning policy, stewardship and monitoring $(2.6 .2 .1,2.6 .2 .5)$.

As both regions' key natural areas have been identified and protected in the Regional Official Plans under the identify and protect the environment policy area, this policy area offers further options to sustainably manage environmentally significant and sensitive areas that are privately owned. The regional policies regarding purchasing development rights exhibit the harmonization integration form, as they enhance the effectiveness of the policy that prioritizes environmental protection by identifying environmentally sensitive and significant areas and protecting them from development.

\section{Density and Intensification Targets}

Policies that establish minimum density and intensification targets for residential, industrial and commercial zones not only lead to the preservation of lands outside the urban growth areas but to a reduction in the fuel consumption needed for transportation associated with low density housing (S. de Wilde, 2004). The regional government can contribute to achieving this policy area by strategically planning land use and through the issuance of building permits, which are defined and approved by local municipalities (Ministry of Municipal Affairs and Housing, 2010).

York and Peel have policies to establish density and intensification targets that meet or exceed the requirements found in the Places to Grow Act's growth plan for the GGH. Both regions have considered the density and intensification targets in their smart development, urban growth boundary, and transport demand management policy areas, and have integrated density decisions into other parts of community planning and triggered "a shift in business- 
as-usual development towards the more compact development" (Urban Strategies Inc., 2005, 9).

Ontario's intensification target of $40 \%$ is still lower than other jurisdictions in Canada, the United Kingdom and Australia, which aim for $60 \%$ to $80 \%$ intensification (Urban Strategies Inc, 2005). In order to maximize the $40 \%$ target, the Places to Grow Act applies the intensification rate to specific areas within the region, such as built up areas, rather than applying them region-wide (Ministry of Public Infrastructure Renewal, 2006; Urban Strategies Inc, 2005). Lower intensification rates are detrimental to becoming more sustainable, although these are much higher than the regions' existing intensification levels of 20\%. (Urban Strategies Inc., 2005).

The established density targets align with urban areas in London, Paris and Amsterdam (S. de Wilde, 2004). In addition, York's floor space indexes of 2.5 to 3.5 per developable area in their regional centres and corridors (5.4.33) are higher overall than similar areas in European cities. Case studies in Europe have revealed that a high floor-space index is more easily achievable for a mono-functional office area than for a functionally diverse area with, for examples, apartments and retail (S. de Wilde, 2004). York's developable areas include residential and employment uses, open space and infrastructure; their floor space indexes are ambitious and reaching them will ensure that compact communities are being developed in the GGH (Region of York, 2009).

The provincial and regional density and intensification targets exhibit both prioritization and harmonization. Prioritization is seen in the density targets and intensification rates defined in the policies, as they favour smart growth objectives to allow communities to grow in a sustainable manner. Harmonization is also reflected because the smart growth concept considers environmental objectives in preventing losing lands to urban 
expansions. In addition, regional policies consider transport demand management in this policy area further supporting environmental and economic objectives equally:

\section{Policy Areas - Environmental Sustainability}

Environmental sustainability is one of the three distinct development processes taking place at the local level. Each of the three processes-economic development, community development and environmental development--has its own unique imperatives. Environmental sustainability involves protecting ecosystems and promoting settlements that reduce environmental degradation (Dale, 2001; Hempel, 1996; ICLEI, IDRC and UNEP, 1996). The policies listed in the category of environmental sustainability in the sustainability framework allow communities to support environmental development by limiting the consumption of natural resources and by reducing the production of waste, with the ultimate goal of reducing consumption to a rate that allows nature to regenerate resources and reducing waste production to levels that can be absorbed by the environment (ICLEI, IDRC and UNEP, 1996).

\section{Identify and Protect the Environment}

The identify and protect the environment policy area concentrates on establishing a systematic identification and strategic protection of environmentally sensitive and biologically significant open spaces in the region, as well as the corridors that connect them, by prohibiting development in these spaces (Jepson, 2004). Saha and Paterson's (2008) survey panel and literature review recognize this policy area as one of the most significant policies to achieve sustainability.

The regions of York and Peel are rich in natural resources, containing portions of the Oak Ridges Moraine and the Niagara Escarpment, which are United Nations Educational, 
Scientific Cultural Organization's World Biosphere Reserve (Region of Peel, 2010a), as well as the regional Greenland System, which contains key natural heritage hydrologic features (Region of York, 2009). The province of Ontario with the powers over the natural resources and the environment has issued legislation, such as the Greenbelt Act, the Oak Ridges Moraine Act, the Lake Simcoe Protection Act and the Provincial Policy Statement, that has contributed to establishing a systematic identification and strategic protection of environmentally sensitive and biologically significant open spaces. Regional Official Plans have identified significant and sensitive areas and their corridors (Peel 2.2.10.4.12, 2.2.9.3.1, 2.3.2.9; York 2.1.11, 2.2.1, 2.2.24) in conforming with provincial legislation. The regions also have policies to continue to identify, refine and verify environmentally sensitive and biologically significant spaces through studies and the establishment and maintenance of environmental management databases (Peel 2.2.2.2, 2.2.2.3; York 2.1.27, 2.2.12). The list of environmental areas that have been identified as significant and sensitive is extensive but the key areas include the regional Greenland System, key natural heritage features, key hydrologic features, woodlands, wetlands, the Oak Ridges Moraine, the Greenbelt area, and Lake Simcoe.

Both regions are committed to protecting, maintaining, enhancing and restoring environmentally sensitive and biologically significant open spaces and the corridors that connect them (Peel 2.1.3.2, 2.5.2.1; York 2.1.7). There are pockets of land designated for protection where development or land-uses are prohibited, but for the most part development and various uses are allowed in protected areas as long as proper studies, assessments and approvals that involve various authorities and meet provincial requirements like the Greenbelt Act are satisfied (Peel 2.3.2.22, 3.2.2.7; York 2.1.8, 2.1.22,6.2.9). For example, Peel prohibits new or expanded mineral aggregate extraction sites, wayside pits and quarries, or any ancillary or accessory uses in the core areas of the Greenlands System (3.3.2.3), while 
York prohibits batching and asphalt plants, and new waste disposal sites anywhere in the Greenland System (2.1.23). Peel's core areas include significant wetlands, core woodlands. provincial natural areas, habitats of threatened and endangered species, core valleys and streams, and escarpment natural areas (Regional of Peel, 2009).

There were only two instances where policies mitigated environmental impacts in the protected areas. The first is within York's Lake Simcoe watershed: the "development or site alteration is to avoid, minimize and/or mitigate impacts associated with the quality and quantity of urban run-off into receiving streams, lakes and wetlands" $(2.2 .22)$. The second instance is for development of wildlife management projects or passive recreation in the core areas of Peel's Greenland System (2.3.2.5). Out of the 304 policies found in both regions' Official Plans that focus on environment, the presence of coordination, is very low.

Regional policies appear to show a preference for applying the precautionary principle by requiring environmental studies and assessments as part of development or site alteration requests in protected areas. The precautionary principle is "Where an activity raises threats of harm to the environment or human health, precautionary measures should be taken even if some cause and effect relationships are not fully established scientifically" - this way the proponent of the activity not the public bears the burden of proof (Global Development Research Centre, 1998). The EPI framework recognizes the precautionary principle as a form of prioritization that favours environmental objectives (Runhaar et al. 2009). On the other hand, the assessments and studies that need to be done could also exhibit coordination, as classification depends on the expectations and the direction of the assessment and the studies, which was not part of the scope of this research. 


\section{Urban Forestry}

The urban forestry policy area supports municipal strategies of planting and maintaining trees with the specific goal of reducing carbon emissions and energy expenditures for heating and cooling (Jepson, 2004). Researchers have reported that greener urban landscapes provide numerous environmental, social and economic benefits by moderating temperature, improving air quality, controlling flooding, causing residents to become more emotionally attached to their communities, and increasing property values (Payton et al., 2008 cited in Heynen and Lindsey, 2003).

Along with their local municipalities, regions are empowered to develop urban forests through planning land use and creating bylaws to manage parks and recreation areas (Ministry of Municipal Affairs and Housing, 2010).

The regions of Peel and York have policies to develop urban forest management plans and strategies (Peel 2.5.2.9; York 2.2.46). The regions are currently involved in conducting urban forest studies that place a monetary and ecological value on the functions of the urban forest, considering factors such as carbon storage, pollutant uptake or the mitigation of energy use. These studies are meant to provide a foundation for the development of the Urban Forest Management Plans (Region of York, 2010a). As this research relies on the content of the policies to perform an analysis, the absence of more descriptive policies regarding the urban forestry plans prevents the use of a coding protocol, EPI framework and comparative analysis.

\section{Energy Conservation}

The energy conservation policy area has had a strong presence in previous sustainability studies (Conroy, 2006; Jepson, 2004; Parkinson and Roseland, 2000; Portney, 2002; Saha and Paterson, 2008) and was identified by Saha and Paterson's (2008) survey 
panel and literature review as one of the policies that is most significant to achieving sustainability, as it limits the consumption of natural resources and reduces pollution emitted from the use of non-renewable sources like coal and fossil fuel. This policy area consists of strategies that focus on energy efficiency measures, including energy conservation efforts, the use of renewable energy like solar and wind, and the green building program (Conroy, 2006; Jepson, 2004; Parkinson and Roseland, 2000; Portney, 2002; Saha and Paterson, 2008). The green building program requires new residential units to achieve substantial reductions in energy and material consumption during both construction and operation (Jepson, 2004).

The province of Ontario is introducing a culture of energy conservation through the Places to Grow Act, the Energy Conservation Responsibility Act in 2006, and the new Green Energy Act in 2008. The Places to Grow Act requires municipalities to design buildings and lands that are energy efficient and reduce consumption, as well as to identify opportunities for alternative energy generation and distribution (Ministry of Public Infrastructure Renewal, 2006).

The Energy Conservation Responsibility Act requires government ministries, agencies and broader public sector organizations to prepare energy conservation plans and report on energy consumption. The Energy Responsibility Act should provide visibility into communities' shift towards a culture of conservation and offer information that can be used to further plan energy-conscious communities (Ministry of Energy and Infrastructure, 2010b). The Green Energy Act, which is meant to invest in renewable energy projects and further increase conservation, has established energy efficiency standards for a wide range of energy-using products, with the objective of eliminating the least energy-efficient products from the Ontario marketplace (Ministry of Energy and Infrastructure, 2010b).

The regions have aligned their Regional Official Plans to support provincial energy conservation legislation through a variety of approaches, including the use of green roofs and 
urban canopy trees, various alternative energy systems such as solar and geothermal energies. and energy conservation plans (Peel 3.7.2.1, 3.7.2.3, 3.7.2.6; York 5.4.6, 5.4.24).

The key difference between the two regions is that York requires its local municipalities to increase building efficiencies $(5.2 .8,5.2 .20,5.2 .42)$ while Peel's policies encourage local municipalities to incorporate policies on energy-efficient buildings into Local Official Plans (3.7.2.2). As discussed earlier, Berke and Manta Conroy's (2000) methodology of suggested versus required policies affects the movement towards achieving sustainability.

Ontario's policies regarding energy conservation have characteristics of harmonization (integrating economic and environmental objectives) due to the energy conservation choices available to the community, from energy-efficient products, which support economic development, to energy conservation land and building designs, which directly preserve the environment.

\section{Water Source Protection and Water Conservation}

The water source protection and water conservation policy area consists of two parts: policies that concentrate on protecting water resources and policies that focus on conserving water use. This policy area, like energy conservation, has a strong presence in previous sustainability studies (Conroy, 2006; Parkinson and Roseland, 2000; Portney, 2002; Saha and Paterson, 2008) and was identified by Saha and Paterson's (2008) survey panel and literature review as one of the policies that is most significant to achieving sustainability.

Ontario is rich in surface and groundwater resources, and communities, plants and animals depend on these resources, which consist of four of the five Great Lakes and more than a quarter of a million lakes, rivers and streams (Ministry of Environment, 2009). The province is responsible for natural resources and the environment, and has defined legislation 
to protect water sources by identifying significant and sensitive water sources as part of Ontario's natural key areas and developing around them (Ministry of Municipal Affairs and Housing, 2010; Ministry of Public Infrastructure Renewal, 2006). To protect the water resources, the regions need to comply with the provincial legislation discussed in the identify and protect the environment policy area along with the Water Resources Act (Government of Ontario, 1990b). Each region has a unique set of tools to protect water sources, including prohibiting incompatible uses, directing development from sensitive surface and groundwater features (Peel 5.9.8.2.3; York 2.3.7), and considering the cumulative impact on water resources in all planning initiatives (Peel 3.4.2.6; York 2.3.33).

With its culture of water conservation, the Places to Grow Act, coupled with the regions' responsibilities over municipal water supply and wastewater systems, allows the regional government to implement water conservation initiatives (Ministry of Municipal Affairs and Housing, 2010). The policies found in the Regional Official Plans offer a range of strategies and tools to reduce water consumption. In York, comprehensive master environmental servicing plans examine all water systems in a comprehensive and integrated manner to increase efficiencies and maximize water conservation in, among other places, buildings and municipal infrastructure (5.6.11). Peel, meanwhile, collaborates with its municipalities to promote water-efficient technologies in new residential development and redevelopment (5.8.5.2.1)

Although both regions have water conservation and water source protection policies, and Peel has measures to restore or enhance degraded water resources (7.6.2.16), York stands out in the water conservation area. York has established water conservation targets above and beyond the Ontario Building Code while Peel has an overall goal of reducing per capita consumption over the next 20 years. York requires that all new buildings achieve $10 \%$ greater water efficiency (5.2.21) and encourages a $20 \%$ greater efficiency than the Ontario Building 
Code (5.2.23). In addition, York encourages new buildings to be designed and certified to LEED Silver, Gold or Platinum standards (5.2.24). Peel recognizes the need to build beyond the minimum Ontario Building Code provisions $(5.8 .5 .2 .3)$ but does not quantify any building water efficiency standards. Although targets do not guarantee improvements or a path to sustainability, they "build momentum for improvement and accurate performance measurements" and create accountability, which can be maintained through monitoring and reporting (Great Lakes United, 2010, 1).

Peel's water efficiency strategy might potentially have another obstacle in sustainable development, its goal to reduce water per capita consumption by $10 \%$ to $15 \%$ over the next 20 years (6.3.2.9). When assessing Canada's progress in addressing the imperatives set out in the Brundtland Report, Tarasofsky (2006) advised that the per capita consumption measure might not be a reliable indicator because as the population grows the per capita consumption does not necessarily increase even though the overall consumption of municipal water does.

As mandated by provincial legislation, both regions apply prioritization in the attempt to protect water resources by reserving water-sensitive and significant areas in order to direct development elsewhere. Protecting water resources is an environmental objective. As discussed in the urban growth boundary and identify and protect the environment policy areas, the regions might practice coordination given the assessments that are performed to determine the impact of land use or development in sensitive areas (Peel 3.4.2.6; York 7.3.41). The requirements of various water studies and risk assessments can determine whether the studies support coordination or prioritization, though the analysis of these studies was not part of the scope of this research.

These water conservation strategies exhibit characteristics of harmonization in the different options that are offered to conserve water use, which will address the environmental 
objectives of reducing water consumption and the economic objectives of minimizing the costs associated with expanding water infrastructure.

\section{Integrated Waste Management}

The integrated waste management policy area concentrates on reducing waste generated through recycling, reusing and conservation efforts (Conroy, 2006; Portney, 2002; Saha and Paterson, 2008). This policy area contributes towards a fundamental sustainability goal of reducing waste to levels that can be absorbed by the environment. With direct responsibility over solid and hazardous waste management, diversion, recycling, composting, processing and disposal, the regions have the power to implement integrated waste management in their communities (Ministry of Municipal Affairs and Housing, 2010).

The regions' waste management strategies aim to reduce, recycle, reuse and recover all forms of waste (Peel 6.4.2.1, 7.6.2.20; York: 7.4.1). Their plans include waste diversion (Peel 6.4.2.3; York 7.4.2), investing in energy-from-waste technologies (Peel 6.4.2.9; York 7.4.19), reducing and reusing construction waste (Peel 6.4.2.14; York 5.2.37), looking for new markets for materials from regional waste programs (Peel 6.4.2.7) and supporting waste prevention legislation (York 7.4.3)

Both York and Peel have targets in place to divert over $90 \%$ and $70 \%$, respectively, of waste from landfills (York 7.4.2) by the year 2016 (Region of Peel, 2010a, 2010c). Many GGH municipalities have increased their diversion rates but considering that North Americans have increased their waste output by more than $80 \%$ in the last 40 years (McKay, 2000) and the difficulty Ontario has experienced in siting a landfill (Watt, 2006, November $1^{51}$ ), increasing diversion rates might not sufficiently address the regions' waste management problem and position municipalities to achieve sustainability. 
These regions are positioned to achieve sustainable waste management given that both regions support extended producer responsibility initiatives (Region of Peel, 2010b; Region of York, 2009) and that York encourages the provincial and federal governments to provide comprehensive packaging reduction (7.4.3).

York and Peel's integrated waste management policies show characteristics of harmonization by providing various means to manage waste sustainably, slowing down the need for new landfills or other forms of expensive waste disposal systems.

\section{Green Procurement}

The green procurement policy area looks for municipal contracts that include requirements for vendors to take back packaging and unused materials and products, and that specify environmentally responsible management practices (Jepson, 2004). With the range of services they provide to their communities, such as roads, water, waste management and land planning, regional governments are for the most part in a position to influence the demand for environmentally preferable goods and services, and to change industries' patterns towards becoming more environmentally sustainable (Ministry of Municipal Affairs and Housing, 2010; Public Works and Government Services Canada, 2009).

The regions of Peel and York have a number of policies that pursue environmentally responsible purchasing practices for regional operations and services (Peel 5.9.8.2.5, 3.7.2.9; York 7.4.16), and that direct the regions and its contractors to follow socially and environmentally responsible practices (York 7.4.18). Neither of the regions have any explicit requirements for vendors to take back packaging and unused materials and products, but both governments are partners with the Greening Greater Toronto Green Procurement initiative to procure local and greener products and services, and to invest locally in green business and technology sectors (Greening Greater Toronto, 2010). 
Green procurement regional policies and initiatives demonstrate harmonization. as environmentally and socially responsible practices with a focus on investing in local communities are more likely to equally consider environmental, social and economic objectives.

\section{Transportation Demand Management}

The transportation demand management policy area consists of policies that encourage the reduction of automobile use through the application of traffic control, public parking, public transit and road strategies (Jepson, 2004). Saha and Paterson's (2008) survey panel and literature review recognized this policy area as one of the policies that is most significant to achieving sustainability. According to Statistics Canada (2006), approximately $75 \%$ of residents in the regions of York and Peel use a car as their main mode of transportation, which if left unmanaged will continue to increase traffic congestion, cause demands for more highway infrastructure and continue to deteriorate air quality (Ministry of Public Infrastructure Renewal, 2006). The regions are empowered by the provincial government to offer transportation demand management strategies, as they are responsible for regional roads, transit services and traffic signals, and local municipalities are responsible for parking enforcement (Ministry of Municipal Affairs and Housing, 2010).

The regions of York and Peel have policies, plans and strategies to reduce the use of single-occupancy vehicles, prioritize pedestrians and cyclists, and support public transit (Peel 5.9.2.2; York 3.2.3). Both regions' policies include parking management, carpooling and car sharing spaces, high-occupancy lanes, improving the transit system and development plans that consider transit when building roads (Peel 5.9.9.2.7, 5.9.9.2.2, 5.9.4.2.13; York 5.2.10, $5.4 .8,7.2 .41,7.2 .24)$ 
Since 2004, the regions of York and Peel, along with other Greater Toronto and Hamilton Area municipalities, have worked with employers to improve and encourage commuting options. Their transport demand management efforts are supported by the central Smart Commute program at Metrolinx, the Ministry of Transportation's Transportation Demand Management Municipal Grant Program and the Federation of Canadian Municipalities' Green Municipal Fund (Federation of Canadian Municipalities, 2009; Ministry of Transportation, 2010).

These regional policies and activities exhibit harmonization, as they offer options to reduce communities' reliance on vehicles, which integrates economic and environmental needs.

\section{Pedestrian and Bicycle Access Plans}

Pedestrian and bicycle access plans policy areas concentrate on an integrated plan of walkways and bicycle lanes for the purpose of improving safety and access to places of employment, home and leisure. These policy areas also look for a separate document that provides a bicycle strategy with an integrated plan of bicycle trails, bike lanes and road crossing that is incorporated with transit support development and transit demand management (Jepson, 2004). Pedestrian and bicycle access plans offer residents choices to incorporate sustainable forms of transportation into their daily activities (Jepson, 2004). Even though the transportation demand management and smart development policy areas move communities away from relying on single-occupancy vehicles and towards public transit, additional focus is needed on active forms of transportation in order to help communities incorporate bicycle and walking into their lives and change the GGH car-based culture (Environmental Commissioner of Ontario, 2007), as only approximately $3 \%$ of residents in York and Peel walk or bike to work (Statistics Canada, 2006). Along with local 
municipalities, the regions are responsible for strategic land-use planning and the design of communities' streets and sidewalks, allowing them to integrate bicycle and pedestrian plans into community designs (Ministry of Municipal Affairs and Housing, 2010).

The Regional Official Plans have policies that integrate bicycle and pedestrian networks into transportation plans, focusing on safety, accessibility and connectivity to recreation, services, employment and transit (Peel 5.9.10.2.1; York 5.6.13). In addition, the regions and their municipalities either have pedestrian and cycling plans or are in the process of developing or re-developing them (Clean Air Partnership, 2010).

The pedestrian and bicycle access plans policies exhibit characteristics of harmonization because they incorporate pedestrian and bicycle design when developing other forms of transportation like roads and transit as well as when developing well-connected neighbourhoods (Peel 5.9.10.2.4; York 3.3.5, 5.2.3). Well-connected neighbourhoods are part of the smart development policy area and entails making sure buildings and facilities are designed to be located in close proximity to pedestrian, cycling and transit systems, and that pedestrian, cycling and transit facilities are safe and accessible year-round.

\section{Public Education of Unsustainable Practices and the Environment}

This policy strategy looks for policies that raise public awareness or educate about unsustainable practices, sustainable development and environmental protection. It is derived from a literature review that focuses on accepting the need for sustainable development in order to achieve sustainability (Dale, 2001). Sustainable development requires a collective shift of individual actions and political choices (Roseland, 2005). Raising the public's awareness is relevant to the collective shift as it addresses the community need to receive better information to allow them to make informed decisions about their daily activities (Environment Canada, 2006), also allowing them to understand how communities need to 
change in order to move towards sustainability. The regions engage the public using various methods, including public meetings, information centres, open houses, stakeholder workshops, newspapers, the internet and written correspondence (York 8.1.2). The Regional Official Plans' policies focus on raising awareness of water, energy and waste conservation, sustainable transportation, the need for affordable housing and the need to create compact communities (Peel 5.9.2.23, 5.9.9.2.5, 5.9.10.2.6; York 5.2.40, 7.4.5). Both regions' education policies address two of the three environmentally unsustainable practices that are prevalent in developed countries: housing and transport (Boyd and Suzuki, 2008). These policies demonstrate harmonization, as they provide public awareness of social issues like affordable housing and economic issues like compact communities while also addressing environmental issues, which are their primary focus.

\section{Policy Areas - Social Sustainability}

Discussions surrounding sustainable development always conclude that environmental and economic imperatives cannot advance without simultaneously making progress in the social and economic life of civil society (Hempel, 1996; WCED, 1987). Achieving social security, meeting the needs of all individuals, and involving and empowering citizens are some of the key principles for sustainable cities (Newman and Jennings, 2008; Pierce and Dale, 1999; Roseland, 2005). It is therefore necessary to consider sustainable social issues when examining sustainability.

Social development needs to distribute benefits equitably and to sustain these benefits for all social groups over the long-term (ICLEI, IDRC and LTNEP, 1996). The policy strategies selected in the sustainability framework under the social pillar of sustainability represent areas where Canadian communities are falling behind when compared with other countries in the Organization for Economic and Cooperation Development (OECD). 
Canadians have a high standard of living, with the second highest GDP per capita, an average unemployment rate, the highest proportion of post-secondary graduates, the lowest school drop-out rate and the second highest life expectancy rate, but the rate and persistence of incidences of low income in Canada are higher than the OECD nations' average, and most of these incidences occur in larger urban areas such as the Greater Toronto Area (Human Resources and Skills Development Canada, 2010).

According to Statistics Canada (2006), 13\% of York's and 14\% of Peel's populations spend $20 \%$ more than average on food, shelter and clothing, and are considered low income (Statistics Canada, 2001); that's approximately 280,000 residents that may not have the resources to afford food, shelter or other necessities, or to ensure their financial and social security. Policies that ensure low income residents have access to affordable transit and housing can improve their financial and social well-being and support sustainable development efforts.

\section{Affordable Transit Access}

The affordable transit access policy area ensures that communities have policies to subsidize the cost of public transportation and provide access to buses, subways and trains in order "to help offset the mobility deprivations of the poor" (Pucher, 1982, 39). Saha and Paterson's (2008) survey panel and literature review recognized this policy area as one of the most significant policies in achieving sustainability.

Regional governments are empowered to provide affordable transit access, as they are responsible for transit services in their communities (Ministry of Municipal Affairs and Housing, 2010). As mentioned earlier, Metrolinx is an important partner to the Places to Grow Act and sustainable transportation. Metrolinx plans to provide service to everyone, regardless of age, means or ability, al though equitable or subsidized transit fare is not 
mentioned in its strategy plans (Metrolinx, 2010b). The region of Peel has no polices to subsidize the public transit system for low income residents. York offers discounts for students and plans to implement an equitable transit fare strategy $(7.1 .16,7.2 .30)$. GGH transportation plans concentrate on developing an environmentally sustainable system. These plans are driven by the fact that Canada has the second highest GHG emissions among OECD countries (Human Resources and Skills Development Canada, 2010) and the lack of a transit system increases traffic congestion and urban sprawl (Ministry of Public Infrastructure Renewal, 2006). Although there are signs within these policies and plans to remove transit service barriers to residents with low income, there are no policies that describe how the subsidized or equitable transit fare will work. In York, the policies mentioned earlier should support harmonization, integrating social development (increasing the prospects of financial and social security for low income residents) with environmental concerns (supporting sustainable transportation).

\section{Affordable Housing}

In Ontario, affordable housing is housing that can be rented or owned at or below the average market value, in many cases at less than $30 \%$ of the gross annual household income for low and moderate income households (Ministry of Municipal Affairs and Housing, 2005). Similar to affordable transit access, this policy area ensures the financial and social wellbeing of residents in low income. Saha and Paterson's (2008) study identified this policy area as one of the policies that is most significant in achieving sustainability. In 2000 , the province of Ontario passed the Social Housing Reform Act, making regional governments responsible for social housing programs, including non-profit housing (ONPHA, 2010). The regions of York and Peel advocate to the provincial and federal governments the need for funding for affordable housing, and have strategies, frameworks and targets in place to implement 
affordable housing (Peel 5.8.2.12, 5.8.5.2.4, 6.2.2.14; York 3.5.6, 3.5.9, 3.5. 24). They both offer a variety of tools to support and promote the development and maintenance of affordable housing, including fast-tracking planning approvals for affordable housing projects (Peel 5.8.3.2.2) and working with the private sectors to consider financial arrangements like reduced municipal fees and charges in order to encourage and support the development and maintenance of affordable housing (York 3.5.10)

The key differences between the two regions are that Peel offers more tools to support affordable housing, such as provisions for rent-geared-to-income components within housing program initiatives (6.2.2.18), income supports for households affected by economic housing barriers (5.8.7.2.4), alternative development standards such as narrow lot sizes, cash in lieu of parking and reduced parking standards (5.8.3.2.3), while York requires affordable housing to meet smart development and intensification requirements (3.5.4). In addition, the regions have different targets-York's targets for affordable housing are $25 \%$ for new housing in each municipality and $35 \%$ for new units in regional centres and key development areas $(3.5 .6,3.5 .7)$, while Peel's target for new units is $17 \%(5.8 .2 .12)$.

York shows signs of placing social and economic objectives on equal terms, which is characteristic of harmonization. It considers affordable housing objectives in density and intensification targets policy area under the economic pillar of sustainability. Lastly, Peel's approach to affordable housing does not appear to be connected to other elements of sustainable development.

\section{Cooperative Housing}

The cooperative housing policy area contains land-use provisions that permit multifamily housing development in which residents have both private and shared spaces under cooperative ownership and management (Jepson, 2004). This policy area has been classified 
under the social development element of sustainability (Saha and Paterson, 2008), as it shares affordable housing's goal of reducing housing costs, and can also result in denser residential development, thus addressing social and environmental objectives of sustainability. In Ontario, cooperative housing is referred to as co-op, which is usually included as part of social or affordable housing, and since the Social Housing Reform Act was passed in 2000 it is a regional responsibility (ONPHA, 2010).

The York and Peel Regions do not have any policies with cooperative land-use provisions but there are 17,000 co-op units in the City of Toronto and York Region, some of which are at market value and some of which are subsidized (CHFT, 2010). Peel has general policies that provide housing options to a diverse population based on their preferences and values $(5.8 .6 .2 .9,5.8 .6 .2 .10)$, and also manages the waiting list for subsidized cooperative housing (Region of Peel, personal communication, July 15, 2010). Lastly, Peel has 16 family cooperative providers in the cities of Brampton and Mississauga (Region of Peel, 2010a). Cooperative housing exists in the communities but is not explicitly mentioned in the Regional Official Plans.

\section{Climate Change Adaptive and Mitigative Policies}

Environment Canada's evaluation of the most significant storms in Ontario in the first few years of the twenty-first century has suggested that communities are increasingly vulnerable to climate change. Models of Ontario weather predict an increase of $30 \%$ to $50 \%$ in extreme rain events by the end of the twenty-first century, which will result in more frequent flooding conditions (EMA Canada Inc., 2008). This century has already redefined the regional storm pattern, as Toronto has seen seven storms in 20 years that have 25 -year return periods. The damage these changing events are causing is severe-the 2005 Toronto 
storm that tore out a portion of Finch Street caused about $\$ 500$ million in damage and is the most expensive storm in Ontario's history (EMA Canada Inc., 2008).

The climate change adaptive and mitigative policy area focuses on protecting communities from the effects of severe weather events caused by climate change, as per Environment's Canada findings. Although the focus is on communities, this does not mean that ecosystems are not impacted, and "There is strong evidence that nonhuman nature is quite vulnerable to climate change... [as] the maximum migration rates of many plant and animal species may not be fast enough to keep pace with climate changes... . [and]... [m]any types of forest require centuries to adapt to changes in temperature and precipitation that greenhouse forces could impose in as little as three or four decades" (Hempel, 1996, 12).

In order for municipalities to move towards sustainability, they need to become more resilient to the effects of climate change (Robinson and Legge, 1990). It is in regional governments' power to make communities respond to climate change by designing infrastructure that is more resilient to the effects of climate change, as well as reducing $\mathrm{GHG}$ emissions within communities (Dale, 2001; George, 2001; Ministry of Municipal Affairs and Housing, 2010).

The region of York currently designs water and wastewater infrastructure that will consider potential climate change effects (7.3.30), while Peel is developing tools to assess air quality implications for human health (2.2.3.3.1). Both regions have policies and plans to manage the effects of climate change as well as to mitigate and adapt to climate change (Peel 7.6.2.3; York 3.2.2). Both regions have policies in place to identify lands subject to flooding hazards, but only York has identified flood management as part of the preparations to manage climate change effects (Peel 2.4.4.2.1; York 2.3.20, 2.3.27).

The regional policies around climate change exhibit characteristics of harmonization, as community needs, economic prosperity and environmental protection that mainly focuses 
on the impact of humans are all considered. The policies related to making communities more resilient to climate change through climate change studies or community designs are viewed as making communities a priority. The policies related to minimizing the impacts of climate change such as promoting sustainable agriculture practices (York 6.3.15) or reducing air pollution (Peel 7.6.2.7) are viewed as making the environment a priority. The fact that the regions have adaptive and mitigative policies will most likely reduce the financial burden a community experiences as a result of severe weather events.

\section{Civic Engagement}

The policy area of civic engagement consists of policies that support individual and collective actions designed to identify and address issues of public concern (Conroy, 2006; Portney, 2002). Community participation and involvement are important factors in developing the political trust and cooperation needed for effective democratic governance (Hempel, 1996), which supports sustainable development because "democracy is fundamental to sustainability" (Roseland, 2005, 193). Ontario's Planning Act requires that municipalities provide a review of the planning process that is fair, open and accessible, with opportunities for the public to be consulted and to review all supporting information and material (Government of Ontario, 1990a). The Places to Grow Act also states that the public needs to be given an opportunity to participate during the review of each growth plan. In order to conform to the Places to Grow Act, the Regional Official Plan review process conducted approximately 15 meetings and generated about 35 reports in Peel, and about 30 meetings and 80 reports in York (Region of Peel, 2010d; Region of York, 2010c).

To support the civic engagement policy area, the region of York encourages volunteerism (3.1.19) and ensures that sufficient information is available in a timely manner to the public and other levels of governments and the planning process is transparent (8.1.1, 
8.1.2). Similarly, Peel provides opportunities for public consultation (7.3.5.2.1) and focuses on forming partnerships to, for example, encourage and facilitate the involvement of service providers, community organizations and stakeholders to address issues related to housing barriers (5.8.7.2.3), and with public and private stakeholders to develop a vision, determine priorities and implement action plans for a sustainable goods movement system in Peel $(5.9 .7 .2 .2)$.

Even though public consultation as laid out in the provincial legislation does not have the level of public involvement and participation that is recommended for sustainable development (Pierce and Dale, 1999; Robison and Legge, 1990; Roseland, 2005), the Places to Grow Act received extensive support from planners, environmentalists and the general public (Wekerle et al., 2007). Ontario and its municipalities' public consultation process has the bare essentials to achieve sustainability, and these essentials include respect for human rights and fundamental freedoms as well as respect for cultural diversity (United Nations Economic and Social Development, 2002).

\section{Summary}

\section{The presence of sustainable activities.}

This analysis found that most of the policy areas in the sustainability framework exist in the regions of Peel and York. Table 3: Presence of Sustainable Activities summarizes the presence of each policy area by region.

The sustainable policy areas that do not exist in Regional Official Plans include the eco-industrial park area in York, and the affordable transit area in Peel. In addition, both regions are developing the urban forestry policy area. Lastly, Peel and its municipalities are in the process of either developing or updating their pedestrian and bicycle access plans. 
Previous sustainability studies experienced similar results. with low level of activities around eco-industrial parks, urban forestry and affordable transit. However, pedestrian and bicycle access plans were policy areas that were frequently cited in most urban areas (Conroy, 2006; Jepson, 2004; Portney, 2002; Saha and Paterson, 2008).

\section{The presence of policy integration.}

Assessing the integration of regional policies can identify contradictions between policies, which can impact communities from becoming more sustainable (Lafferty and Hovden, 2003). The objectives of the three sustainability pillars often contradict one another (ICLEI, IDRC and UNEP, 1996). For instance, the externalization of costs for private profit can contradict the environmental objective to value and conserve natural resources. The global expansion of markets and the integration of national economies and free-trade agreements can undermine community objectives of local self-reliance (ICLEI, IDRC and UNEP, 1996). As mentioned earlier, one of the key defining features of sustainability is the emphasis on the integration of environmental objectives into non-environmental policy-sectors (Lafferty and Hovden, 2003) and the fact that sustainability cannot be achieved without all three elements progressing together simultaneously (Hempel, 1996; WCED, 1987).

An integration framework like the EPI offers a tool to recognize signs of integration, providing insight into which elements of sustainability are integrated and to what degree (Runhaar et al., 2009). The EPI was modified from its original focus on environmental integration for this research, expanding to consider environmental as well as social and economic objectives. Table 4 shows the results of the integration analysis. 
Table 4: Results from the Integration Analvsis

\begin{tabular}{|c|c|c|c|c|}
\hline \multirow{2}{*}{$\begin{array}{l}\text { Sustainable } \\
\text { Policy Areas }\end{array}$} & \multicolumn{2}{|c|}{ Peel Region } & \multicolumn{2}{|c|}{ York Region } \\
\hline & Integration Form & $\begin{array}{l}\text { Integrated } \\
\text { Elements }\end{array}$ & Integration Form & $\begin{array}{l}\text { Integrated } \\
\text { Elements }\end{array}$ \\
\hline \multicolumn{5}{|c|}{ Economic Sustainability } \\
\hline $\begin{array}{l}\text { Urban growth } \\
\text { boundary }\end{array}$ & $\begin{array}{l}\text { Prioritization of } \\
\text { smart growth } \\
\text { - Harmonization } \\
\text { Environmental } \\
\text { coordination }\end{array}$ & $\begin{array}{l}\text { Economic and } \\
\text { environment }\end{array}$ & $\begin{array}{l}\text { Prioritization of } \\
\text { smart growth } \\
\text { - } \begin{array}{l}\text { Harmonization } \\
\text { Environmental } \\
\text { coordination }\end{array} \\
\end{array}$ & $\begin{array}{l}\text { Economic, } \\
\text { social and } \\
\text { environment }\end{array}$ \\
\hline Smart development & Harmonization & $\begin{array}{c}\text { Economic and } \\
\text { environment }\end{array}$ & Harmonization & $\begin{array}{c}\text { Economic and } \\
\text { environment }\end{array}$ \\
\hline Eco-industrial park & No policy data & & No policy data & \\
\hline $\begin{array}{l}\text { Purchase of } \\
\text { development rights }\end{array}$ & Harmonization & $\begin{array}{c}\text { Economic and } \\
\text { environment }\end{array}$ & Harmonization & $\begin{array}{c}\text { Economic and } \\
\text { environment }\end{array}$ \\
\hline $\begin{array}{l}\text { Density and } \\
\text { intensification } \\
\text { targets }\end{array}$ & $\begin{array}{l}\text { Prioritization of } \\
\text { smart growth } \\
\text { - Harmonization }\end{array}$ & $\begin{array}{l}\text { Economic and } \\
\text { environment }\end{array}$ & $\begin{array}{l}\text { Prioritization of } \\
\text { smart growth } \\
\text { - Harmonization }\end{array}$ & $\begin{array}{c}\text { Economic and } \\
\text { environment }\end{array}$ \\
\hline \multicolumn{5}{|c|}{ Environmental Sustainability } \\
\hline $\begin{array}{l}\text { Identify and protect } \\
\text { environment }\end{array}$ & $\begin{array}{l}\text { Prioritization of } \\
\text { environment } \\
\text { Environmental } \\
\text { coordination }\end{array}$ & & $\begin{array}{l}\text { Prioritization of } \\
\text { environment } \\
\text { - Environmental } \\
\text { coordination }\end{array}$ & \\
\hline $\begin{array}{l}\text { Urban forestry } \\
\text { program }\end{array}$ & No policy data & & No policy data & \\
\hline Energy conservation & Harmonization & $\begin{array}{c}\text { Economic and } \\
\text { environment }\end{array}$ & Harmonization & $\begin{array}{c}\text { Economic and } \\
\text { environment }\end{array}$ \\
\hline $\begin{array}{l}\text { Water conservation } \\
\text { and water sources } \\
\text { protection }\end{array}$ & $\begin{array}{l}\text { Water sources } \\
\text { protection: } \\
\text { - Prioritization of } \\
\text { environment } \\
\text { - Environmental } \\
\text { coordination? } \\
\text { Water conservation: } \\
\text { - Harmonization }\end{array}$ & $\begin{array}{l}\text { Water } \\
\text { conservation: } \\
\text { Economic and } \\
\text { environment }\end{array}$ & $\begin{array}{l}\text { Water sources } \\
\text { protection: } \\
\text { - Prioritization of } \\
\text { environment } \\
\text { - Environmental } \\
\text { coordination? } \\
\text { Water conservation: } \\
\text { - Harmonization }\end{array}$ & $\begin{array}{l}\text { Water } \\
\text { conservation: } \\
\text { Economic and } \\
\text { environment }\end{array}$ \\
\hline $\begin{array}{l}\text { Integrated waste } \\
\text { management }\end{array}$ & Harmonization & $\begin{array}{c}\text { Economic and } \\
\text { environment }\end{array}$ & Harmonization & $\begin{array}{c}\text { Economic and } \\
\text { environment }\end{array}$ \\
\hline Green procurement & Harmonization & $\begin{array}{l}\text { Economic, } \\
\text { social and } \\
\text { environment }\end{array}$ & Harmonization & $\begin{array}{l}\text { Economic, } \\
\text { social and } \\
\text { environment }\end{array}$ \\
\hline $\begin{array}{l}\text { Transportation } \\
\text { demand } \\
\text { management }\end{array}$ & Harmonization & $\begin{array}{l}\text { Economic and } \\
\text { environment }\end{array}$ & Harmonization & $\begin{array}{l}\text { Economic and } \\
\text { environment }\end{array}$ \\
\hline $\begin{array}{l}\text { Pedestrian access } \\
\text { plan }\end{array}$ & Harmonization & $\begin{array}{l}\text { Economic and } \\
\text { environment }\end{array}$ & Harmonization & $\begin{array}{c}\text { Economic and } \\
\text { environment }\end{array}$ \\
\hline
\end{tabular}




\begin{tabular}{|c|c|c|c|c|}
\hline Bicycle access plan & Harmonization & $\begin{array}{l}\text { Economic and } \\
\text { environment }\end{array}$ & Harmonization & $\begin{array}{l}\text { Economic and } \\
\text { environment }\end{array}$ \\
\hline $\begin{array}{l}\text { Public education on } \\
\text { unsustainable } \\
\text { practices }\end{array}$ & Harmonization & $\begin{array}{l}\text { Economic, } \\
\text { social and } \\
\text { environment }\end{array}$ & Harmonization & $\begin{array}{l}\text { Economic, } \\
\text { social and } \\
\text { environment }\end{array}$ \\
\hline \multicolumn{5}{|l|}{ Social Sustainability } \\
\hline Affordable transit & No policy data & & Harmonization & $\begin{array}{l}\text { Social and } \\
\text { environment }\end{array}$ \\
\hline Affordable housing & No integration & & Harmonization & $\begin{array}{c}\text { Economic and } \\
\text { social }\end{array}$ \\
\hline Cooperative housing & No policy data & & No policy data & \\
\hline Climate change & Harmonization & $\begin{array}{l}\text { Economic, } \\
\text { social and } \\
\text { environment }\end{array}$ & Harmonization & $\begin{array}{l}\text { Economic, } \\
\text { social and } \\
\text { environment }\end{array}$ \\
\hline Civic engagement & Harmonization & $\begin{array}{l}\text { Economic, } \\
\text { social and } \\
\text { environment }\end{array}$ & Harmonization & $\begin{array}{c}\text { Economic, } \\
\text { social and } \\
\text { environment } \\
\end{array}$ \\
\hline \multicolumn{5}{|c|}{ Summary of Integration Incidences } \\
\hline Harmonization & 14 & & 16 & 1 \\
\hline $\begin{array}{l}\text { Environment } \\
\text { and economic }\end{array}$ & 10 & & 9 & \\
\hline $\begin{array}{l}\text { Social and } \\
\text { economic }\end{array}$ & 0 & & 1 & \\
\hline $\begin{array}{ll}\text { - Social and } \\
\text { environment }\end{array}$ & 0 & & 1 & \\
\hline $\begin{array}{l}\text { Environment, } \\
\text { social and } \\
\text { economic } \\
\end{array}$ & 4 & & 5 & \\
\hline Prioritization & 4 & & 4 & \\
\hline - Economic & 2 & & 2 & \\
\hline - Environment & 2 & & 2 & \\
\hline - Social & 0 & & 0 & \\
\hline $\begin{array}{l}\text { Environmental } \\
\text { Coordination }\end{array}$ & 3 & & 3 & \\
\hline No Integration & 1 & & $\mathbf{0}$ & \\
\hline No Policy Data & 4 & & 3 & \\
\hline
\end{tabular}

Harmonization was the most common type of integration assigned to the policy areas, occurring approximately $60 \%$ of the time in York and 50\% in Peel. Peel has more policy areas than York that integrate the economic with the environmental elements. The region of York has more policy areas than Peel that integrate the three elements of sustainability. Peel 
does not integrate its affordable housing policies with other elements of sustainability while York integrates its policy areas with at least one element of sustainability.

In each region, prioritization and coordination each occurred about $20 \%$ to $25 \%$ of the time. The policy areas that prioritized the protection of natural resources were usually accompanied by a set of studies to determine whether or not the protected area was impacted by development. A review of the content of the numerous studies identified in the Regional Official Plans is not part of the scope of this research, and the details of these studies are not always included in the policy descriptions. Similar to the requirements of the municipal comprehensive reviews, in the urban growth boundary policy area the details of environmental studies can provide insight whether they are supporting coordination or prioritization, with the former limiting and the latter improving the movement towards achieving sustainability.

Finding that harmonization is present in most policy areas in York and Peel suggests that there are signs that the sustainability elements are moving simultaneously towards sustainability. This increases the chances of achieving sustainability, as the aim of harmonization is "to promote synergy and enhance the effectiveness of ... policy sectors" (Runhaar et al., 2008, 422). The fact that both regions primarily integrate through a form of harmonization, the economic and environmental elements of sustainability suggests that the regions are moving towards more sustainable economic and environmental practices.

\section{Regional comparison.}

The comparative analysis examines two regions' policies subject to the same provincial land-use framework, the same planning review approach through a lens of sustainability, and with both having characteristics that according to Portney (2002) relate to how seriously a community is involved in sustainability efforts. The objective of the 
comparative analysis is to learn about the strengths and weaknesses that such municipalities brings towards achieving sustainability. Portney (2002) found that communities with a lower percentage of manufacturing services or with older population are the communities that take sustainability the most seriously. Both regions have a low manufacturing presence as well as a low percentage of younger population, see Table 2: Regional Profile.

The following list is a summary of observations from the comparative analysis of York and Peel that summarizes factors that are believed to impact their move towards sustainability:

- York has a low presence of integrated bike lanes, while Peel has no presence of integrated bike lanes in the smart development policy area. Cycling is one form of active transportation that can contribute to reducing Canada's GHG emissions, and it needs to have more presence in the communities for the public to make the shift from being car-dependent to an active form of transportation.

- Peel encourages its local municipalities to incorporate smart development and energy conservation policy areas in Local Official Plans, while York requires its municipalities to comply. As per Berke and Manta Conroy's (2000) methodology, policies that are suggested decrease the chances of moving towards sustainability.

- Peel's water conservation measure of consumption per capita might provide unreliable data to assess whether the community's policies follow the most sustainable path.

- York links its flood management to climate change strategies. The integration of environmental elements of sustainability into other sectors in community planning helps make policies mutually supportive in achieving the policy's objectives (Lafferty and Houden, 2003). 
The regional policy comparative analysis provides insight into whether the Regions are moving towards achieving sustainability from a different angle than the previous two levels of analysis. The first level revealed the sustainability-focused policy areas that are present in the regions and the second level focused on the types of integration that take place between the pillars of sustainability, while the comparative analysis focused on the differences in policy content that can impact becoming more sustainable. The different approaches a community takes towards achieving the same goal can provide insight into the prospects of that approach to achieving the goal. The directives found in York and Peel's policies can further support or hinder the movement towards sustainability. For instance, a region's choice of applying voluntary policy tools can reduce the prospects of moving towards sustainability, as per Berke and Manta Conroy's (2000) methodology, and as can be seen in Peel's energy conservation and smart development policies.

\section{Research Limitations}

The study was mainly limited by a number of scope decisions, which were made in order to examine a topic as complex in nature as sustainability in the planning process. The research was limited as its methodology was guided by the objectives of a single piece of provincial legislation, the Places to Grow Act. Even though the goal of the Places to Grow $A c t$ is to manage growth in a sustainable manner, the multi and self-organizing environmental, economic and social systems of sustainable development cannot be captured in a single piece of legislation. In addition, the study was limited by focusing on the Regional Official Plans, which restricted the scope to mostly land-use planning policies. These scope restrictions were apparent when the Regional Official Plans or the Places to Grow Act did not include any policies supporting certain policy areas in the sustainability framework, including 
green procurement and eco-industrial parks, which the Regions are actively pursuing. In addition, the study's focus on regional government prevented a complete view of local govemments' movement towards achieving sustainability, as governmental responsibilities in Ontario are distributed among provincial, regional and municipal governments.

This research focused solely on policy content and did not oblain the regions' views, experiences and policy directions, and these are not considered in the research's findings and conclusion. Lastly, the study assumes that each policy area is equally important in contributing to a community becoming more sustainable. Some previous studies weighted policy areas (Parkinson and Roseland, 2002) but most did not discuss the importance of each policy area in creating greater sustainability (Berke and Manta Conroy, 2000; Conroy, 2006; Jepson, 2004; Portney, 2002; Saha and Paterson, 2008). The literature review found no consistent way of weighting the overall contributions of sustainable measures in achieving greater sustainability (Abolina and Zilans, 2002; Berke and Manta Conroy, 2000; Conroy, 2006: Jepson, 2004; Parkinson and Roseland, 2002; Portney, 2002; Saha and Paterson, 2008; Tsenkova and Damiani, 2009) thus no weighted index was applied to this study's policy areas.

\section{Findings}

What contributions do the regions of York and Peel make in moving towards sustainability? Their Regional Official Plans support $95 \%$ of sustainability-focused policy areas, which were identified in previous studies as contributing to achieving sustainability (Berke and Manta Conroy, 2000; Conroy, 2006; Jepson, 2004; Parkinson and Roseland, . 2002; Portney, 2002; Saha and Paterson, 2008). Most of the regions' sustainability-focused policies exhibit harmonization, the majority of which inteorate economic and environmental elements of sustainability. The integration of the economy and the environment aligns with 
the goals of the Places to Grow Act, which are to manage growth in a sustainable manner and create a cleaner environment in order to secure the future prosperity of the GGH (Ministry of Public Infrastructure Renewal, 2006). However, the primary focus is still economic performance, and understandably so-as discussed earlier, urbanization and economic performance are closely linked (Chakrabarty, 2001 cited in World Bank, 1991 and Cheema, 1993).

Based on the finding that the regions' policies have signs of integrating environmental and economic elements, and the high presence of sustainability-focused policy areas, the regions appear to be in the position of moving towards economic and environmental sustainability. However, public support and the federal and provincial governments' financial assistance are the determining factors as to whether the regions will become more sustainable. In addition, there are a number of directives discussed in the comparative analysis that can hinder the move towards sustainability, including voluntary policies, a lack of active transportation, targets that are linked to minimal changes in community designs (such as lower intensification rates) and indicators that may mislead a community as to its progress. It was found that Peel has a higher presence than York of factors that can weaken the path towards achieving sustainability.

Public support and the financial assistance from higher levels of govemment were recognized as factors that can help, delay or hold back the community in moving towards sustainability (Jepson, 2004). At the moment, the public is supportive and the governments" plans indicate that substantial financial assistance is going to be required to implement the Places to Grow Act and other sustainability-focused legislation. The Ontario budget's trend of allocating more funding to urban roads instead of active transportation weakens the move towards achieving sustainability, and this trend was continued in both the 2008 and 2010 Ontario budgets (Ross, 2008; Anonymous, 2010, April 30). 
Planning for only environmental and economic sustainability is a common occurrence in urban communities but it leaves economic and environmental issues isolated from social development (Saha and Paterson, 2008; Tsenkova and Damiani, 2009) and prevents the realization of sustainable development. Failing to integrate social development into sustainability can impede progress towards achieving economic and environmental sustainability, as the process of integration can remove contradictions between the policies and make them mutually supportive, a benefit that is not realized when full integration has not taken place (Lafferty and Houden, 2003). Approximately $30 \%$ of the harmonized policy areas consider economic, social and environmental objectives simultaneously, while the remaining $70 \%$ concentrate on integrating environmental and economic elements only. Does this mean that York and Peel's low-income population will remain isolated from the economic and environmental benefits the regions have to offer, and that Canada will continue to have more frequent incidences of low income than the OECD average? The region of Peel has no policy data in its Regional Official Plans on affordable transit and no signs of related regional initiatives. In addition, with no integration of affordable housing policies with other elements of sustainability, the prospects of improving their social situation in a sustainable manner are low. The region of York can potentially integrate its affordable transit policy with environmental objectives, as York's single policy on affordable transit vaguely refers to providing an equitable transit strategy, though York does integrate its affordable housing with economic objectives. York more strongly integrates its social policy than Peel does, increasing York's prospects of improving the lives of its low income population.

What does this mean to the immigrant population that makes up almost half of Peel and York's population? (Statistics Canada, 2006). According to Statistics Canada (2006), Ontario continues to be the province of choice for more than half of the newcomers who arrive in Canada, with most immigrants settling in the Greater Toronto Area. Regions that 
have a stronger and more sustainable social foundation will not only provide social security and opportunities to become financially secure but will also improve the path towards achieving sustainability. 


\section{Chapter 4: Conclusion}

The goal of this study was to provide insight whether the Regions of York and Peel are moving towards achieving sustainability. This study demonstrates that the regions have laid a foundation in achieving environmental and economic elements of sustainability, but have not reached full sustainability. In conforming to the Places to Grow Act, Regional Official Plans have the ability to address unsustainable practices like the over-use of natural resources for housing and transport purposes that are found in a developed country (Boyd and Suzuki, 2008). The movement towards achieving environmental and economic objectives can be diminished or improved by the federal and provincial governments' financial and policy support, by the specific content and direction of regional policy, such as whether a policy measure is able to provide reliable data or by integrating economic and environmental objectives with social needs. This research's findings agree with previous studies with respect to not connecting social equity and justice issues to sustainability (Saha and Paterson, 2008). This is not to say that governments in Ontario have taken an entirely piecemeal approach as was found in other sustainability studies (Saha and Paterson, 2008; Tsenkova and Damiani, 2009), as this study finds that environmental and economic integration have a substantial presence in York and Peel's Regional Official Plans (Berke and Manta Conroy, 2000; Conroy, 2006; Jepson, 2004; Parkinson and Roseland, 2002; Portney, 2002; Saha and Paterson, 2008).

Since the Ontario governments have not laid a foundation towards achieving sustainability, the results from the comparison and integration analyses offer insight that can be used to improve the move towards sustainable development, especially when it comes to setting realistic but ambitious targets and the extent to which policies' details are mutually 
supportive in achieving the overall goal. The policies'. weaknesses identified from the comparative analysis can be examined to determine whether these policies warrant changes in order to improve the path towards achieving sustainability. Many of the environmentalists' concerns about the lack of rapid responses to deal with global environmental problems are valid as seen in this study's results: legislation and plans based on sustainable development principles have established a foundation to move the communities towards more sustainable economic and environmental practices but not sustainability (Hempel, 1996). In addition, some of the policy directives suggest that the targets defined to prevent further environmental degradation might be misleading or they are not as ambitious to protect the environment as other urban areas in a developed country.

The key lessons from this study regard the research's methodology compared to the results obtained. It is well-known that the Places to Grow Act and its growth plan have the potential to address the GGH environmental degradation. The act is known as having a scope that is "breathtaking" (Ross, 2008, 25) and is recognized through a number of awards, such as the Daniel Burnham Award from the American Planning Association (Ministry of Energy and Infrastructure, 2010c). The intent of this study was to perform a detailed analysis in order to move beyond simply looking for the signs of sustainability in the form of the presence or absence of policy areas and actions that have or have not been taken, and provide insight into whether the Regions are moving towards sustainable development. This study could have provided more insight into the movement towards sustainability by establishing clear and detailed sustainability objectives for each sustainable element within each policy area. During the analysis it became evident that the objectives for each sustainability element were not defined to the level of detail required, which did not support the detailed nature of the analysis and limited the integration analysis. 
Do regions currently have tools in place to perform a sustainability check before policies are implemented? Does the province carry out any sustainability checks before it approves Regional Official Plans? This research's recommendation is that a sustainability policy check is valuable to any community working towards sustainable development. It will identify any policy issues during the policy design phase rather than uncovering them over a period of time. The method presented in this paper is a starting point that needs to be refined and built upon. The method used in this research is open to many changes, including making the sustainability framework more equitable by having an equal number of policy areas supporting each element, modifying the policy integration forms to consider other policy sectors, and applying the tool to one policy area (for instance, the area of active transportation in the GGH, as this issue touches on all imperatives of sustainability and crosses multiple communities). The recommendation is meant not only to perform a sustainability check at the time the policy planning exercise is completed but every time a new initiative, program or legislation is planned.

The scope of this study was to analyze only two regions because of the exploratory and detailed nature of the analysis, but it makes sense to apply the sustainability check to all regions within the GGH, as the Places to Grow Act's growth plan was created for the GGH. This research expects the findings from the six regions to be much different than the findings from York and Peel because of the variety of community profiles and cultures. Some regions might not have as many of the characteristics that Portney (2002) found that make communities treat sustainability more seriously. From the news releases of regions' progress in conforming to the Places to Grow Act, some regions like Durham might have a weaker presence of smart development provisions, as it wants to continue to offer its communities single detached housing. One region's "sprawl-friendly" lifestyle will probably have an effect 
on the smart growth in other regions in terms of population growth, and housing and land costs (Anonymous, 2010, June 7).

Future research can review the methodology explored in this study to determine if existing policy planning tools already address similar sustainability checks, and to what extent. Moving forward, research needs to question the benefits of such sustainability tools in comparison to the effort invested in using them. If the value of these tools warrants the effort, the methodology presented in this paper needs to be refined and built upon by carrying out the suggestions made throughout this chapter. Another potential research topic can be to determine the government level most suited to using this type of tool in order to best understand whether the legislation, plans and communities support the move towards sustainability. An examination at a provincial level will provide insight into the contradictions, weaknesses and strengths that the provincial (that is, provincial and municipal) activities contribute towards sustainable development, while an examination at a federal level will provide insight into the federal, provincial and municipal contributions towards sustainability.

Sustainability requires personal and institutional changes that strengthen capacities for both cooperation and ecological awareness (Hempel, 1996). It requires a new way of planning and governing communities with goals that place equal value on environmental, social and economic imperatives (Dale, 2001). It challenges policymakers to find the right combination of new policy directions, governmental cooperation, public support and financial priorities to support the complexities and the changing dynamics of communities' sustainability needs (Robinson, 2008). 


\section{Appendices:}

\section{Appendix A: Federal, Provincial and Municipal Governments Responsibilities}

Division of Governmental Responsibilities

(City of Brampton, 2010; Ministry of Municipal Affairs and Housing, 2010).

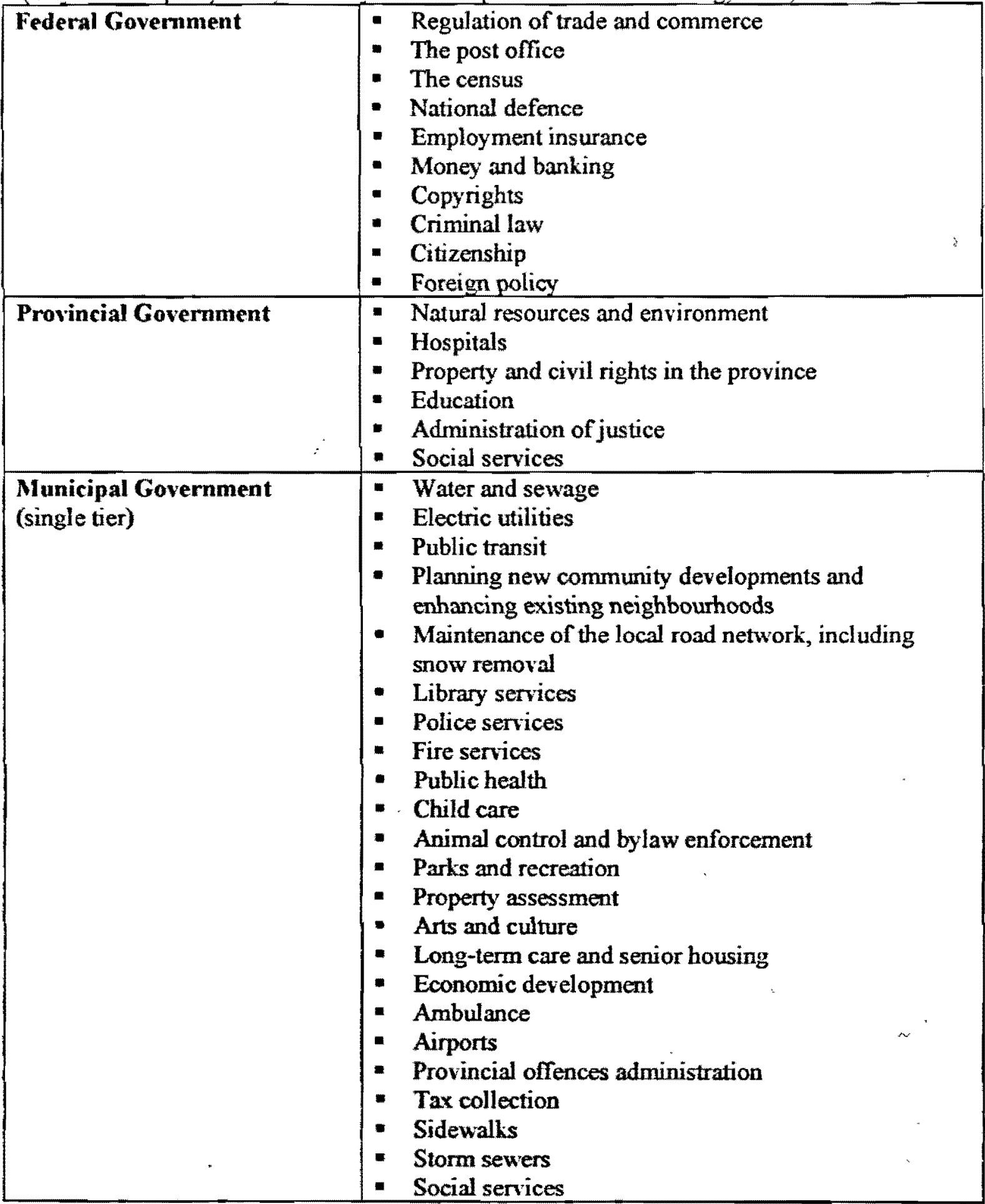




\begin{tabular}{|c|c|}
\hline & $\begin{array}{l}\text { Social housing } \\
\text { Garbage collection and recycling }\end{array}$ \\
\hline $\begin{array}{l}\text { Municipal Government } \\
\text { (upper tier - region) }\end{array}$ & $\begin{array}{l}\text { - Strategic land-use planning } \\
\text { - } \text { - Waste collection and recycling } \\
\text { - Police services } \\
\text { - Water treatment and supply } \\
\text { - Public health } \\
\text { - Wastewater collection and treatment } \\
\text { - } \text { Hocial services } \\
\text { Housing services }\end{array}$ \\
\hline $\begin{array}{l}\text { Municipal Government } \\
\text { (lower tier - municipalities) }\end{array}$ & $\begin{array}{l}\text { - Animal control } \\
\text { - } \text { Arovincial offences administration } \\
\text { - Planning new community developments and } \\
\text { - } \text { Enhancing existing neighbourhoods } \\
\text { - Public transit } \\
\text { - Economic development } \\
\text { - } \text { Local roads } \\
\text { - Tire services } \\
\text { - Pax collection } \\
\text { - Snow and recreation } \\
\text { - }\end{array}$ \\
\hline
\end{tabular}




\section{Appendix B: Map of York and Peel Regions}

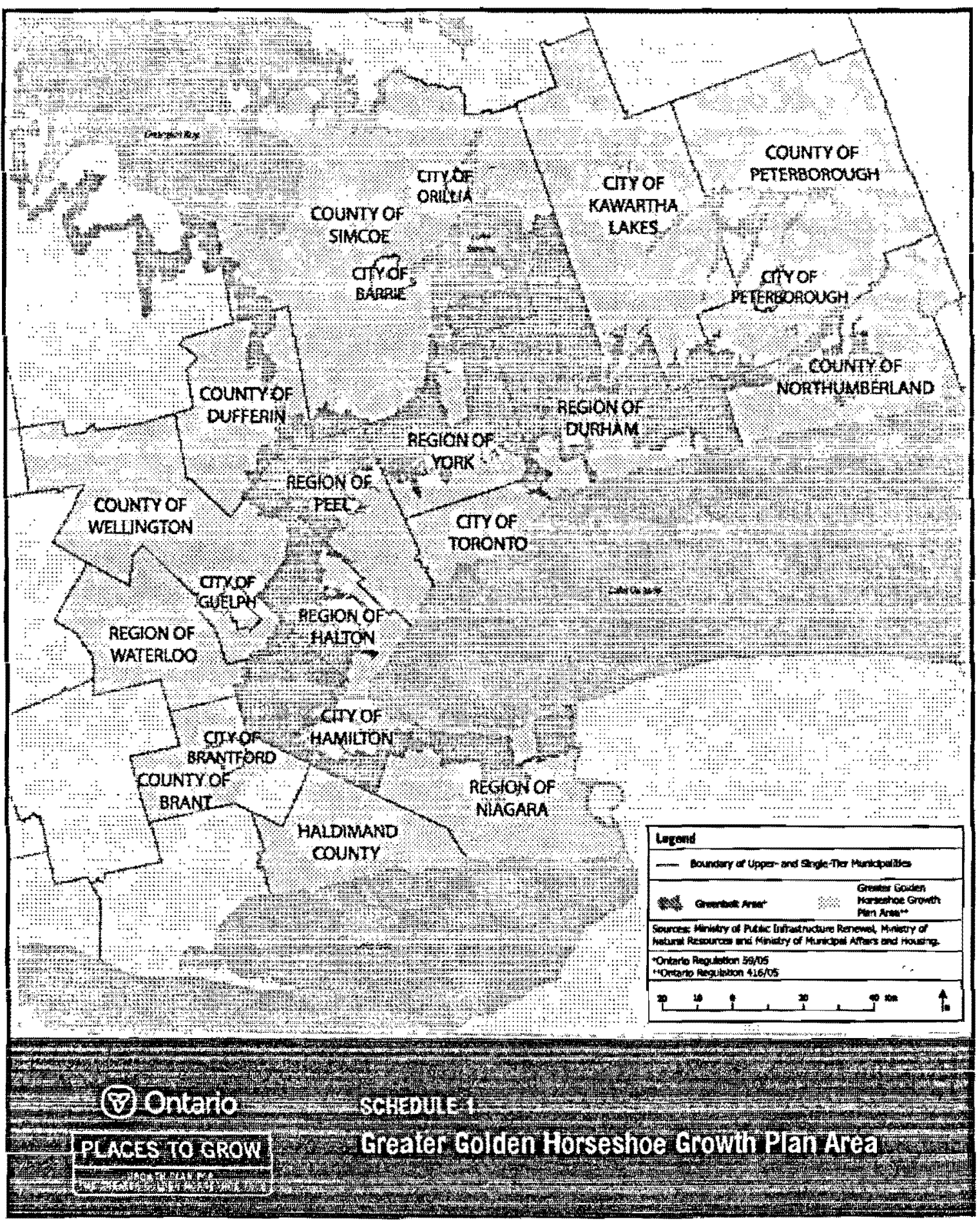




\begin{tabular}{|l|l|}
\hline \multicolumn{1}{|c|}{ Policy Strategies / Areas } & \multicolumn{1}{|c|}{ Peel Regional Official Plan Policies } \\
\hline Economic Sustainability & \multicolumn{1}{|l|}{$\begin{array}{l}\text { Summary of Findings: } \\
\text { The Region which consists of urban and rural areas, both of which are identified in ROP (5.4.2.1), have } \\
\text { established boundaries for built up areas, designated greenfield areas (5.5.3.2.1), employment lands within } \\
\text { Urban and Rural areas (5.6.2.1), core areas of the Greenland System. } \\
\text { Within the Urban areas, lines were established around Urban Growth Centres, Intensification Corridors, } \\
\text { Urban Nodes, Major Transit Station Areas (5.5.3.2.5, 5.5.3.2.6) and Urban System (5.3.2.1). Within Urban } \\
\text { Areas lines were established around natural and resources land (5.3.2.1). }\end{array}$} \\
\hline $\begin{array}{l}\text { Urban Growth Boundary - } \\
\text { policies establishing lines } \\
\text { around a community/region and } \\
\text { the application of zoning } \\
\text { regulations that restrict urban } \\
\text { development to the areas inside } \\
\text { the line. }\end{array}$ & $\begin{array}{l}\text { In the Rural Areas, three Rural Service Centres were identified (5.4.3.2.1, 5.3.2.1), they are Mayfield West, } \\
\text { Bolton and Caledon East (5.4.3.2.6, 5.4.3.2.7,5.4.3.2.2) and settlement area which was identified as the } \\
\text { Caledon East Rural Service Centre (2.2.9.3.7, 5.4.5.2.1). In addition, policy 5.4.5.2.1 defined the boundaries } \\
\text { around the Palgrave Estate Residential Community. Lastly, study areas were identified and study of } \\
\text { employment lands within the three rural service centres/settlements (5.6.2.4). }\end{array}$ \\
$\begin{array}{l}\text { The Region requires that between 2015 and 2025 40 percent of the Region's residential development, } \\
\text { annually, will occur within the built up area, and after 2025, 50 percent of the Region's residential } \\
\text { development occur within the built up area, annually (5.5.3.2.4, 5.5.3.2.5). The Region will direct a } \\
\text { significant portion of new growth to the built up areas through intensification (5.5.2.2). Intensification is } \\
\text { required in Urban Growth Centres, Intensification Corridors, Nodes, Major Transit Stations and other } \\
\text { appropriate areas within the built up area (5.5.3.2.3). Lastly, it is prohibited to establish new settlements } \\
\text { areas (5.5.2.4) and the Region is protecting employment lands around airports and major highways } \\
\text { (5.6.2.10) by prohibiting the development, redevelopment and infill of new residential and sensitive land }\end{array}$ \\
\hline
\end{tabular}


uses around airports (5.9.6.2.4) and making the requests to convert lands from employment to nonemployment go through a municipal comprehensive review $(5,6.2 .6)$.

The Rural areas direct the growth to the three Rural Service Centres, the Palgrave Estate Residential Community, other rural settlements (lands already committed for residential development) as designated in local official plans and the Niagara Escarpment, Greenbelt and Growth Plans (5.4.5.2.2, 5.4.5.2.3, 5.4.2.2, 5.4.4.2.3). The Rural areas also require to prepare a secondary plan prior to releasing lands for estate . residential development outlining the detailed land uses (5.4.3.2.3) and only allowed development if infrastructure is there to support it as well as it is compatible with the community and environment is protected (5.4.3.2.3).

The Region will prepare a growth management and phasing strategies which will address and incorporate issues such as the improvement of live-work relationships, appropriate levels of industrial-commercial to total assessment ratio, priority growth areas, Growth Plan policies and targets, sustainable rate of employment growth related to population growth (5.2.2.1). The Region will direct development and redevelopment to the Urban System (5.3.2.2) according to the growth management phasing strategies (5.3.2.4). Cities of Brampton and Mississauga are required to provide opportunities for compact forms of urban development and redevelopment with commercial, residential, recreational, cultural and civic activities that offer a wide range of goods and services to the residents and workers of Peel Region and other residents of the Greater Toronto Area and Hamilton (5.3.3.2.1). Lastly, Northwest Brampton development is to ensure an orderly progression of development in relation to the ongoing development of lands within the existing urban boundary. In addition, this area is to provide for the protection and potential use of the shale resource, while recognizing the long-term use of these lands will be for urban purposes (5.3.4.1.8) and meet the requirements of the Growth Plan (5.3.4.1.7).

Most of the policies focusing on extensions or expansions of established lines or boundaries require that the ROP to be amended if boundaries will be modified (5.4.4.2.2, 5.3.3.2.2). This impacts urban growth centres, rural service centres, the Palgrave Estate Residential Community, urban or rural settlements and boundaries. The other common requirement that requests for boundary expansions need to meet is that they will support ROP's intensification and density targets $(5.4 .4 .2 .2,5.5 .3 .2 .8,5.5 .4 .2 .4)$. Last requirement is to complete a comprehensive analysis (5.2.2.3) especially for regional urban boundary. Minor adjustments do not require amendments to the plan (5.2.2.2. and 7.2.2.7). 
Smart Development - zoning provisions that permit integrated development projects characterized by mixed uses, high densities, centralized common areas, distributed and accessible open space, health care and recreational facilities, and an integrated system of walkways, bikeways and transit.
Overall, this analysis has identified 62 policies related to establishing lines around a community/region and the application of zoning regulations that restrict urban development to the areas inside the line. Most of the policies, 31 were focused on development, 25 policies focused on designating boundaries and 12 policies dealt with boundary expansions.

\section{Additional Policies:}

2.2.10.4.20 Permit at the 10-year Greenbelt Plan review period, modest settlement area expansions for Towns/Villages, provided the proposed growth:

- b) Would not exceed the assimilative and water production capacities of the local environment as determined on a watershed or subwatershed basis;

- c) Complies with any applicable watershed plan;

- d) Does not extend into the Natural Heritage System;

2.2.10.4.22 Where the Town of Caledon had initiated the consideration of a settlement expansion within the Protected Countryside prior to December 16, 2004, such an expansion may be considered through the Town's exercise to bring its official plan into conformity with the Greenbelt Plan.

2.2.10.5.12 Require, where settlement area expansions are contemplated, the completion or approval of the environmental assessment in support of expanded sewage and water services prior to amending the boundaries of the settlement within the municipal official plan. The expansion must not extend into the Natural Heritage System.

\section{Summary of Findings}

Four smart development policies were coded for this research. The four policies provided provisions for mix use, high densities, accessible open space, health care and recreational facilities, and an integrated system of walkways and transit. None of these policies mentioned providing an integrated bicycle system. In two of the policies, which provided provisions for mix use, high density and an integrated system of walkways and transit, the Region required the local municipalities to include these provisions in the local official plans (5.3.3.2.3 5.3.3.2.4). The other two policies, the Region is encouraging the local municipalities to consider in their policies provisions for mix use, an integrated system of walkways and transit, high quality public open space and easy access to retail and services, where the analysis interpret the services as health care and recreations facilities (5.3.2.6 and 5.5.2.1). The required policies focused on Urban Growth Centres while the voluntary policies focused on Urban System and Communities. 
5.6.2.12 Encourage the planning and development of employment land in a manner consistent with sustainable development imperatives as outlined in the Themes of the Plan in section 1.3.5 of this Plan. Energy efficient buildings that meet Regional green development standards will be encouraged.

The over-arching theme of this Plan (section 1.3.5 of ROP) is sustainability which refers to meeting the needs of

the present without compromising the ability of future generations to meet their own needs. Regional

Council will work towards sustainability by applying a sustainable development framework which will provide a holistic approach to planning, action and measurement. Peel's environment imperative seeks to

Policies to manage development by defining eco-industrial parks
Purchase of development rights policy allowing the municipality to purchase development rights from landowner for areas that have received special conservation designation.

Policies establishing minimum density targets requirements for industrial, commercial and residential zones reduce Greenhouse Gas (GHG) emissions and other pollutants while promoting best practices in sustainable development including use of green development standards, energy and water efficient systems and living within the carrying capacity of Peel's supporting ecosystems. The economic imperative is to promote a strong, vibrant and prosperous economy that operates within the sustainability theme while encouraging environmentally friendly businesses and business practices.

This voluntary policy aligns to the Peel's sustainable development framework described in theme of ROP. Policy 5.6.2.12 has signs and potential to be a policy which manages eco-industrial parks. Eco-industrial characteristics include the planning and development of environmentally friendly business, business practices and employment lands in sustainable manner but it directly does not support the management of eco-industrial parks.

2.6.2.1 Support Greenlands securement initiatives in Peel through planning policy, stewardship, monitoring and land acquisition;

2.6.2.5 Support the securement of natural areas through planning policy, stewardship and monitoring before land acquisition is considered.

The Region promotes and facilitates intensification (5.5.3.2.2) and with the collaboration with the area municipalities and other stakeholders such as the conservation authorities, the building and development industry, and landowners encourages new residential development, redevelopment and intensification in support of Regional and area municipal official plan policies promoting compact forms of development and 
residential intensification (5.8.2.6). In addition, Peel

encourages the area municipalities to establish policies which support residential redevelopment in appropriate areas that have sufficient existing or planned infrastructure, and, cost-effective and compact forms of development standards for new residential and other types of development, redevelopment, and intensification $(5.8 .2 .2,5.3 .2 .3)$.

5.3.3.2.4 Require the area municipalities to prepare, in a reasonable time frame if they have not already effectively done so, policies for the Urban Growth Centres that are identified in this Plan and consistent with the Growth Plan, addressing the following: e) the achievement of a minimum gross density target of 200 residents and jobs combined per hectare by 2031 or earlier;

The Region plans to achieve a minimum greenfield density target of 50 people and jobs combined per hectare by 2031 , to be measured over Peel's designated greenfield area excluding major environmental features as defined by the Growth Plan or comparable Regional methodology (5.5.4.2.1) and has provided an additional density target option for the local municipalities of a minimum of 60 residents per hectare and a minimum of 35 jobs per hectare to be achieved by 2031 (5.5.4.2.2). In addition, the Region encourages the local municipalities to require development around major transit stations within the designated greenfield area to achieve a minimum density of 100 residents and jobs combined per hectare $(5.5 .4 .2 .6)$ and a density of 50 jobs per hectare in employment land to contribute to achieving the greenfield density target (5.6.2.13). The Region with the local municipalities will identify the areas within the designated greenfield area where development will need to be phased to achieve a minimum greenfield density of 50 residents and jobs combined per hectare $(5.5 .4 .2 .3)$

The Growth Plan and the Region have identified intensification targets for residential development. Peel requires that by 2015 and for each year until 2025 , a minimum of 40 per cent of the Region's residential development occurring annually to be located within the built-up area (5.5.3.2.4) and that by 2026 and for each year thereafter, a minimum of 50 per cent of the Region's residential development occurring annually will be within the built-up area (5.5.3.2.5).

The Region also requires the local municipalities to develop intensification strategies that, among other things, identify urban growh centres, intensification corridors, urban nodes, major transit station areas and other intensification areas to support achievement of the intensification objectives (5.5.3.2.6) and to consider expansion of the 2031 Urban Boundary or settlement boundary only if such expansion supports achieving the minimum intensification targets established by policies 5.5.3.2.4 and 5.5.3.2.5 and is 
consistent with the ROP's Performance Measurement Program (5.5.3.2.8), which is a mechanism for measuring and evaluating the effectiveness of the policies and related metrics (Section 7.9 of ROP). Lastly, The Region encourages the local municipalities to add a density bonusing provision in their respective official plans and develop detailed implementation guidelines and protocols (5.8.3.2.4). Density bonusing is a local municipality by-law which authorizes the increases in the height and density of development in return for the provision of such facilities, services or matters as are set out in the by-law. Examples of provisions may include affordable housing, underground parking, parkland, daycare facilities, and more (ROP Glossary).

\section{Add These Policies:}

2.2.10.4.21 Permit infill and intensification within the approved boundaries of Hamlets in the Protected Countryside, subject to appropriate water and sewage services. (part of Greenbelt section in ROP)

2.2.10.5.14 Permit only in the following circumstances new or expanded partial servicing, if site conditions are suitable for the long-term provision of such services:

- Where such servicing is necessary to address failed individual on-site sewage or water services serving existing development; or

- To allow for infilling and intensification within settlement areas served by partial services as of the date the Greenbelt Plan came into effect."

\section{Environmental Sustainability}

Policy establishing a systematic identification and strategic protection of environmentally sensitive and biologically significant open spaces in the region and corridors to connect them by prohibiting development in these spaces

\section{Identify: Summary of Findings:}

The Region recognizes the Oak Ridges Moraine as a provincially significant feature (2.2.9.3.1), and considers the following as environmentally and biologically sensitive and significant spaces: key natural heritage features, key hydrologic features, natural heritage system, the Greenland System and woodlands.

The Region defines key natural heritage features as outlined in the ORMCP, they are (2.2.9.3.9):

- Wetlands;

- Significant portions of the habitat of endangered, rare and threatened species;c) Fish habitat;

- Areas of natural and scientific interest (life science);

- Significant valleylands;

- Significant woodlands;

- Significant wildlife habitat; and 
- Sand barrens, savannahs and tall grass prairies.

Peel defines the key natural heritage features within the Natural Heritage System of the Greenbelt Plan the same as in the ORMCP but it adds fish habitat and alvars (2.2.10.4.12). Key natural heritage features outside of the Natural Heritage System within the Protected Countryside of the Greenbelt Plan shall be defined in accordance with the Greenlands System policies of this Plan (2.2.10.4.13).

The Natural Heritage System includes areas of the Protected Countryside with the highest concentration of the most sensitive and/or significant natural features and functions. These areas need to be managed as a connected and integrated natural heritage system given the functional inter-relationships between them, and the fact this system builds upon the natural systems contained in the NEP and the ORMCP. Together with the landscape surrounding the Greenbelt, these systems currently comprise, and function as, a connected natural heritage system. The Natural Heritage System is not a designation in and of itself with a list of permitted uses. Rather, it functions as an overlay on top of the prime agricultural and/or rural area designations contained in municipal official plans (Greenbelt Plan, 2005).

The Region identifies the Natural Heritage System as an overlay designation of the Protected Countryside and directs the Town of Caledon and City of Brampton to identify in the local official plan schedules the Natural Heritage System as an overlay designation of the Protected Countryside (2.2.10.4.7).

The Region defines hydrologically sensitive features as outlined in the ORMCP, they are (2.2.9.3.10):

- Permanent and intermittent streams;

- Wetlands;

- Kettle lakes; and

- Seepage areas and springs.

Pell defines key hydrologic features within the Protected Countryside of the Greenbelt Plan the same as features outlined in the ORMCP except kettle lakes are replaced by lakes (and their littoral zones) $(2.2 .10 .4 .14)$

It directs the Town of Caledon to identify the location of known key natural heritage features and known hydrologically sensitive features in its Official Plan and Zoning By-law where such identification is technically feasible (2.2.9.3.11). 
The Region does need to identify key natural heritage features and key hydrologic features in accordance with criteria established by the Province where such identification is technically feasible (2.2.10.4.15).

The Greenlands System in Peel is being made up of Core Areas, Natural Areas and Corridors and Potential Natural Areas and Corridors (2.3.2.1).

The Core Areas consist of (2.3.2.2):

- Significant wetlands (Class 1-3)

- Significant coastal wetlands

- Core woodlands

- Environmentally Sensitive or Significant Areas;

- Provincial Life Science Areas of Natural and Scientific Interest;

- Significant habitats of threatened and endangered species

- Escarpment Natural Areas of the Niagara Escarpment Plan; and

- Core valley and stream corridors. Core valley and stream corridors include the main branches, major tributaries and other tributaries associated with the Credit River, the Etobicoke Creek, the Mimico Creek, the West Humber River and the Humber River and with the other identified watercourses draining directly to Lake Ontario; except for those portions in the Rural Service Centres and the rural settlements in the Rural System as designated in an area municipal official plan. These valley and stream corridors are continuous linkages connecting to other elements of the Greenlands System Core Areas.

According to policy 2.3.2.4, the local municipalities may define local core areas and policies in their Official Plans which will, at a minimum, incorporate the Core Areas of the Greenlands System in Peel.

The Natural Areas and Corridors consist of (2.3.2.8):

- evaluated non-provincially significant wetlands

- NAC woodlands meeting one or more of the criteria in Table 1

- significant wildlife habitat meeting one or more of the criteria in Figure 5

- regionally significant life science Areas of Natural and Scientific Interest

- provincially significant earth science Areas of Natural and Scientific Interest

- Escarpment Protection Areas of the Niagara Escarpment Plan

- the Lake Ontario shoreline and littoral zone and other natural lakes and their shorelines 
- any other valley and stream corridors that have not been defined as part of the Core Areas;

- headwater source and discharge areas; and

- any other natural features and functional areas interpreted as part of the Greenlands System Natural Areas and

- Corridors by the individual area municipalities, in consultation with the conservation authorities and the Ministry of Natural Resources, including, as appropriate, elements of the Potential Natural Areas and Corridors.

The Potential Natural Areas and Corridors consists of (2.3.2.9) subject to the provisions of policy 2.3.2.8 (i) as:

- unevaluated wetlands;

- cultural woodlands and cultural savannahs within the Urban System and Rural Service Centres meeting one or more of the criteria in Table 1. The evaluation of cultural woodlands and cultural savannahs is also subject to policy 2.3.2.18.

- any other woodlands greater than 0.5 hectares ( 1.24 acres);

- regionally significant earth science Areas of Natural and Scientific Interest;

- sensitive groundwater recharge areas;

- portions of Historic shorelines;

- open space portions of the Parkway Belt West Plan Area;

- potential ESA's identified as such by the conservation authorities; and

- any other natural features and functional areas interpreted as part of the Greenlands System Potential Natural Areas and Corridors, by the individual area municipalities in consultation with the conservation authorities. "

The Region directs the local municipalities to interpret woodlands to include plantations except where a more detailed environmental study has demonstrated that the plantation does not exhibit the characteristics necessary to satisfy the definition of woodlands in this Plan, in which case, the plantation shall not be considered to be a woodland for the purposes of this Plan (2.3.2.17) and to include or develop criteria and thresholds for woodlands identified as Natural Areas and Corridors and Potential Natural Areas and Corridors in accordance with the criteria in Table 1 and to consider criteria and thresholds based on environmental, physiographic, social and economic factors (2.3.2.19). 
The Region supports, in consultation with the local municipalities, the conservation authorities, the Niagara Escarpment Commission, where applicable, and the Ministry of Natural Resources to define the boundaries of the Greenlands System in Peel in terms of functions, landforms, attributes, linkages, critical elements, and rehabilitation and natural habitat restoration opportunities,

including the preparation of technical documents (2.3.2.11). In addition, Peel supports the joint efforts of the conservation authorities and area municipalities to continue to refine mapping with respect to Environmentally Sensitive or Significant Areas and ravine, valley and stream corridors, including headwater areas and setbacks from the water course and/or valley walls and the other components of the natural environment in Peel, as appropriate (7.6.2.12).

Lastly, the Region supports studies and the creation of databases for the larger environmental systems (2.2.2.2) and to participate in, and support, broader scale environmental studies in order to assess the carrying capacity of ecosystems and the potential cumulative effects of development in areas where development is likely to have a major impact on the integrity of broader ecosystems and the Greenlands System in Peel (see Section 2.3) (2.2.2.3).

\section{Protect}

\section{General - Summary of Findings}

The Region protects, maintains and enhances the quality and integrity of ecosystems, including air, water, land and biota jointly with the area municipalities, conservation authorities and provincial agencies (2.1.3.2), including Natural Areas and Corridors and Potential Natural Areas and Corridors (2.3.2.10). It supports the conservation authorities which own and maintain conservation areas on a region-wide basis (3.5.2.4). It promotes a wide range of environmental enhancement and restoration opportunities (2.5.2.1) and adopts policies and establishes programs for the restoration of the natural environment in Peel jointly with the area municipalities, conservation authorities and provincial agencies (2.1.3.4).

The Region studies, recognizes and protects the overall integrity of Peel's ecosystems which are part of connected biotic (living) and abiotic (non-living) systems providing local and large scale natural functions (2.2.2.1) and rationalizes the regulatory framework for the natural environment across the Region on an ecosystem basis, jointly with the area municipalities, conservation authorities and provincial agencies, to 
It encourage and promote jointly with conservation authorities, the area municipalities and other agencies, habitat restoration and enhancement programs through the planning approvals process (2.5.2.3), the maintenance and enhancement of the natural environment, the open landscape and the natural scenery within the area of the Niagara Escarpment Plan in accordance with the objectives of the Niagara Escarpment Planning and Development Act and the Niagara Escarpment Plan (2.5.2.4).

The Region will apply policies that are the most restrictive policies, except where prohibited by the Greenbelt Plan $(2,2.10 .3,2)$, it permits the local municipalities to be more restrictive in its official plans and zoning by-laws, except as prohibited by the Greenbelt Plan (2.2.10.3.6) and lastly it permits the Town of Caledon to be more restrictive in its Official Plan and Zoning By-law, except as prohibited by the ORMCP $(2,2.9 .3 .5)$.

\section{Mineral aggregate operations}

3.2.2.6 Require that all extraction and processing and ancillary or accessory use there to be located, designed and operated so as to minimize environmental, community and social impacts.(ROPA 24) 3.2.2.7 Conduct such studies and address, as it considers appropriate, jointly with the area municipalities, the cumulative effects of the establishment and expansion of mineral aggregate extraction sites on Peel's communities, natural environment and cultural features.

3.2.2.8 Promote progressive rehabilitation of licensed mineral aggregate extraction sites in a manner that conforms with the applicable policies in this Plan, the area municipal official plans, the Niagara Escarpment Plan, the Oak Ridges Moraine Conservation Plan, Greenbelt Plan, Provincial Policy Statement, and the Aggregate Resources Act.

3.3.2.2 Permit mineral aggregate extraction sites, inside or outside of the HPMARA (High Potential Mineral Aggregate Resource Areas), only where extraction is permitted in an area municipal official plan and only in conformity with this Plan, the Niagara Escarpment Plan, the Oak Ridges Moraine Conservation Plan, the Greenbelt Plan and the Provincial Policy Statement where applicable. An amendment to Schedule $\mathrm{C}$ will not be required for the establishment or expansion of a mineral aggregate extraction site. 


\section{Greenland System:}

2.3.2.3 Direct the area municipalities, in consultation with the conservation authorities, the Province and the Niagara Escarpment Commission, to include objectives and policies in their official plans for the interpretation, protection, enhancement, proper management and stewardship of the Core Areas of the Greenlands System in Peel which conform to the intent of this Plan, consistent with provincial policy, the Niagara Escarpment Plan, the Oak Ridges Moraine Conservation Plan and the Greenbelt Plan, where applicable

2.5.2.6 Support and encourage all efforts, including those of the area municipalities and conservation authorities, in restoring and enhancing components of the Greenlands System.

2.5.2.8 Work jointly with the agencies and landowners to implement reforestation programs across the Region with the highest priority on those areas that will enhance the Greenlands System in Peel.

2.3.2.6 Ensure that the Core Areas of the Greenlands System in Peel are not damaged or destroyed. In the event that portions of the Core Areas are damaged or destroyed, there shall be no adjustment to the boundary or redesignation of these areas in the area municipal official plans and the Region will require replacement or rehabilitation of the ecological features, functions and/or landforms. Regional Council will support the area municipalities in applying this policy to other environmental features that are protected in an approved area official plan.

2.3.2.5 Prohibit development and site alterations within the Core Areas of the Greenlands System in Peel, except for:

- forest, fish and wildlife management;

- conservation and flood or erosion control projects, but only if they have been demonstrated to be necessary in the public interest and after all reasonable alternatives have been considered;

- essential infrastructure exempted or authorized under an environmental assessment process;

- passive recreation;

- minor development and minor site alteration; and

- existing uses, buildings or structures; expansions to existing agricultural buildings and structures, single residential dwellings, and accessory uses, buildings and structures to both; new buildings and structures that are accessory to existing agricultural and residential uses; and a new single residential dwelling on an existing lot of record, provided that the dwelling would have been permitted by the applicable planning legislation or zoning by-law on the date of approval of this Plan.

The above exceptions may be permitted through an approved area municipal official plan or the Niagara Escarpment Plan where 
applicable, in consultation with the Region, the conservation authorities, the Niagara Escarpment

Commission and other relevant agencies, provided that the policies which permit such uses and activities are in conformity with the objectives and policies of this Plan. The area municipalities are directed to adopt appropriate policies to allow the exceptions subject to it being demonstrated that:

- there is no alternative location outside of the Core Area and the use, development or site alteration is directed away from the Core Area feature to the greatest extent possible; and

- the impact to the Core Area feature is minimized and any impact to the feature or its functions that cannot be avoided is mitigated through restoration or enhancement to the greatest extent possible.

Notwithstanding the above exceptions, no new development or site alteration shall be permitted within the significant habitat of endangered and threatened species, significant wetlands and significant coastal wetlands except as may be authorized in accordance with provincial legislation.

2.3.2.22 Direct the area municipalities to require environmental impact studies for development and site alteration within and on adjacent lands to the Greenlands System and to include policies in their official plans that development and site alteration shall not be permitted unless the ecological functions of the adjacent lands have been evaluated and it has been demonstrated that there will be no negative impacts on the natural feature or its functions or the requirements of Section 2.3.2.5 have been satisfied. This requirement for environmental impact studies may be reduced if detailed development criteria have been applied to a site through a subwatershed study, a comprehensive environmental impact study, or if an appropriate scoping exercise has been completed by the area municipality in consultation with the relevant agencies.

2.2.9.3.7 New permitted uses in natural core systems, are generally related to conservation and resource management, low intensity recreation, or agriculture subject to other provisions of the ORMCP. In natural linkage areas, new permitted uses include those that are permitted in Natural Core Area's as well as mineral aggregate operations and wayside pits, subject to other provisions in the ORMCP.

2.3.2.7 Allow the continuation of existing agricultural uses in accordance with normal farm practices within the Greenlands System.

7.6.2.10 Review the Region's natural heritage system policy framework to address policy gaps, develop Regional Greenland System tools, actions and resources to address future system planning needs in the Region (which will include identifying system and system studies)

2.5.3.2.2 Support and encourage the area municipalities in consultation with the conservation authorities to develop policies and programs that require or promote measures to eliminate and/or manage non-native 
invasive species and discourage the use of non-native invasive species plantings in new developments adjacent to the Greenlands System.

3.3.2.5 Exempt from Policies 2.3.2.5 (Prohibit development and site alterations within the Core Areas of the Greenlands System in Peel), 2.3.2.6 (not damaged or destroyed) and 3.3.2.3 any areas designated for mineral aggregate extraction in an area municipal official plan at the time of the approval of this Plan. 3.3.2.3 Prohibit new or expanded mineral aggregate extraction sites and wayside pits and quarries or any ancillary or accessory uses there to in a) the Core Areas of the Greenlands System;

\section{Summary of Findings (Greenland System):}

The Region directs to its local municipalities and supports the protection, enhancement, restoration, proper management and stewardship of the Core Areas of the Greenlands System in Peel which conform to the intent of the ROP, is consistent with provincial policy, the Niagara Escarpment Plan, the Oak Ridges Moraine Conservation Plan and the Greenbelt Plan, where applicable (2.3.2.3, 2.5.2.6, 2.5.2.8). The Region ensures that the Core Areas of the Greenlands System in Peel are not damaged or destroyed and if they are, Peel requires restoration and will not expand any boundaries as a result of the damage (2.3.2.6).

In addition, Peel reviews the Region's natural heritage system policy framework to address policy gaps, develop Regional Greenland System tools, actions and resources to address future system planning needs in the Region (7.6.2.10).

The Region does not permit development or site alterations within the Core Areas of the Greenlands System in Peel except for specific uses which might be permitted through an approved area municipal official plan or the Niagara Escarpment Plan where

Applicable and demonstrated that there is no alternative location and that impact to the environment will be minimal (2.3.2.5)

In addition, Peel requires environmental impact studies for development and site alteration within and on adjacent lands to the Greenlands System (2.3.2.22).

New permitted uses in natural core systems, are generally related to conservation and resource management, low intensity recreation, or agriculture subject to other provisions of the ORMCP. In natural linkage areas, new permitted uses include those that are permitted in Natural Core Area's as well as mineral aggregate operations and wayside pits, subject to other provisions in the ORMCP (2.2.9.3.7). Lastly, The Region allows the continuation of existing agricultural uses in accordance with normal farm practices within the 
Greenlands System (2.3.2.7).

The Region supports and encourages the local municipalities to develop policies and programs that require or promote measures to eliminate and/or manage non-native invasive species and discourage the use of nonnative invasive species plantings in new developments adjacent to the Greenlands System (2.5.3.2.2).

Lastly, any areas designated for mineral aggregate extraction in local official plan at the time of the approval of this Plan, are permitted to proceed and operate (3.3.2.5) but the Region prohibits new or expanded mineral aggregate extraction sites and wayside pits and quarries or any ancillary or accessory uses in the Core Areas of the Greenlands System (3.3.2.3).

\section{Key Natural Heritage and Key Hierological Sensitive Features - Summary of Findings:}

The Region directs the Town of Caledon to include in its Official Plan, appropriate policies to protect unevaluated and unmapped

key natural heritage features and hydrologically sensitive features (2.2.9.3.12).

The Region prohibits, subject to jurisdictional limitations, transportation, utility, and infrastructure uses in all land use designations and key natural heritage features and hydrologically sensitive features unless the requirements of the ORMCP or the Greenbelt Plan have been addressed to the satisfaction of the applicable approval authority, such as the Region of Peel and the Town of Caledon, in consultation with other relevant agencies, as appropriate $(2.2 .9 .3 .20,2.2 .10 .5 .5)$. It also prohibits the carrying out of new agricultural uses and agriculture-related uses, which commence after November 15, 2001 within a key natural heritage feature, a hierologically sensitive feature, and within the associated minimum vegetation protection zone (2.2.9.3.16). Lastly, it prohibits the City of Brampton and the Town of Caledon to locate storm water management ponds in key natural heritage features or key hydrologic features or their vegetation protection zones, in accordance with the Greenbelt Plan (2.2.10.5.16).

The Region directs the Town of Caledon to prohibit development and site alteration within a key natural heritage feature and/or a

hydrologically sensitive feature and within the associated minimum vegetation protection zone, in 
accordance with the Table in Part III of the ORMCP, except as permitted by the ORMCP (e.g. existing uses and existing lots of record). (2.2.9.3.13). It directs to require that an application for new development or site alteration within the minimum area of influence of a key natural heritage feature or a hydrologically sensitive feature be accompanied by a natural heritage evaluation and/or a hydrological evaluation, as detailed in the ORMCP (2.2.9.3). In addition, Peel directs the Town of Caledon and the City of Brampton to include appropriate policies in their official plans for development and site alteration in the Natural Heritage System to ensure that key natural heritage features, key hydrologic features and other natural features are evaluated and protected in accordance with the Greenbelt Plan. These policies should also address how connectivity between key natural heritage features and key hydrologic features is to be maintained, or where possible, enhanced $(2.2 .10 .4 .8,2.2 .10 .4 .16)$.

Peel requires that the location and construction practices of infrastructure and expansions, extensions, operations and maintenance of infrastructure in the Protected Countryside minimize, wherever possible, the amount of the Greenbelt, and particularly the Natural Heritage System, traversed and/or occupied by such infrastructure, minimize the negative impacts and disturbance of the existing landscape, including, but not limited to, impacts caused by light intrusion, noise and road salt, existing capacity and coordination with different infrastructure services is optimized, shall avoid key natural heritage features, key hydrologic features and Natural Heritage system unless need has been demonstrated and it has been established that there is no reasonable alternative (2.2.10.5.7).

Lastly, the Region prohibits new or expanded mineral aggregate extraction sites and wayside pits and quarries or any ancillary or accessory uses in key natural heritage features and hydrologically sensitive features and the associated minimum vegetation protection zone, as defined by the Oak Ridges Moraine Conservation Plan, within the Oak Ridges Moraine Conservation Plan Area, except as permitted by the Oak Ridges Moraine Conservation Plan (3.3.2.3, 2.2.9.3.17).

\section{Natural Heritage Systen - Summary of Findings}

2.2.10.4.9 Direct the Town of Caledon and the City of Brampton to include appropriate policies in their official plans to require applicants proposing non-agricultural uses, except as it relates to non-renewable resources, within the Natural Heritage System, to demonstrate that:

- at least 30 percent of the total developable area of the site will remain or be returned to natural selfsustaining vegetation; 
- connectivity along the system and between key natural heritage features and key hydrologic features located within 240 metres of each other is maintained or enhanced; and

- buildings or structures do not occupy more than 25 percent of the total developable area and are planned to optimize the compatibility of the project with the natural surroundings.

2.2.10.4.20 Permit at the 10-year Greenbelt Plan review period, modest settlement area expansions for Towns/Villages, provided the proposed growth:

- b) Would not exceed the assimilative and water production capacities of the local environment as determined on a watershed or subwatershed basis;

- c) Complies with any applicable watershed plan;

- d) Does not extend into the Natural Heritage System;

2.2.10.5.21 Require that final rehabilitation in the Natural Heritage System will meet the following provisions:

- Where there is no underwater extraction, an amount of land equal to that under natural vegetated cover prior to extraction, and no less than $35 \%$ of each license, is to be rehabilitated to forest cover, which shall be representative of the natural ecosystem in that particular setting or ecodistrict;

- Where there is underwater extraction, no less than $35 \%$ of the non-aquatic lands of each license is to be rehabilitated to forest cover, which shall be representative of the natural ecosystem in that particular setting or ecodistrict; and

- Rehabilitation will be implemented so that the connectivity of the key natural heritage features and the key hydrologic features on the site and on adjacent lands will be maintained or restored, and to the extent possible, improved.

2.2.10.5.12 Require, where settlement area expansions are contemplated, the completion or approval of the environmental assessment in support of expanded sewage and water services prior to amending the boundaries of the settlement within the municipal official plan. The expansion must not extend into the Natural Heritage System.

\section{Protected Country Side - Summary of Findings:}

All applications for development or site alteration within the Protected Countryside, which commenced on or after December 16, 2004, are required to conform to the Greenbelt Plan (2.2.10.3.5). The Region permits all existing, expanded or new infrastructure, that is subject to and approved under the Canadian Environmental Assessment Act, the Environmental Assessment Act, the Planning Act, the Aggregate 
Resources Act, the Telecommunications Act or by the National or Ontario Energy Boards, or which receives a similar environmental approval, within the Protected Countryside, provided it either supports agriculture, recreation and tourism, rural settlement areas, resource use or the rural economic activity that exists and is permitted within the Greenbelt; or it serves the significant growth and economic development expected in southern Ontario beyond the Greenbelt by providing for the appropriate infrastructure connections among urban growth centres and between these centres and Ontario's borders (2.2.10.5.6).

It also permits uses and activities that are related to the use of renewable resources, in accordance with the Greenbelt Plan and all other applicable legislation, regulations and municipal planning documents, including the PPS (2.2.10.5.18).

The Region directs the City of Brampton and the Town of Caledon to require storm water management plans for applications for development and site alteration in the Protected Countryside. These storm water management plans shall meet the objectives of the Greenbelt Plan and demonstrates that construction practices will minimize vegetation removal, grading and soil compaction, sediment erosion and impervious surfaces, an integrated treatment approach shall be used to minimize storm water management flows and structures through such measures as lot level controls and conveyance techniques such as grass swales; and that applicable recommendations, standards or targets within watershed plans and water budgets are complied with $(2.2 .10 .5 .17)$

The Town of Caledon areas within the Protected Countryside are permitted to expand settlement area into rural areas subject to the Greenbelt Plan ((2.2.10.4.5) as well as to extend or expand services to the settlement areas subject to the infrastructure policies of Section 2.2.10.5 of this Plan, including the requirements regarding environmental assessments (2.2.10.4.19).

The Region directs the Town of Caledon to require that proponents for proposals for non-agricultural uses in the rural areas of the Protected Countryside demonstrate that, among other things, that there are no negative impacts on key natural heritage features and/or key hydrologic features or their functions $(2.2,10.5 .2)$.

The Protected Country Side is allowed most uses and developments but they are subject to the Greenbelt 
Plan, PPS and ROP policies and some require additional environmental studies. There are not as many requirements to protect the environment as in the Greenland System nor not as many restrictions by allowing more uses.

The Region prohibits mineral aggregate operations or wayside pits within the Protected Countryside of the Greenbelt unless the appropriate requirements identified in the Greenbelt Plan, and the applicable policies of this Plan and the City of Brampton and Town of Caledon Official Plans, have been addressed to the satisfaction of the Region of Peel, the City of Brampton and the Town of Caledon, in consultation with the applicable conservation authority (2.2.10.5.19). And when the operators undertake the rehabilitation of mineral aggregate operation sites in the Protected Countryside they are required to be consistent with the requirements of the Greenbelt Plan (2.2.10.5.20).

\section{Greenbelt and Oak Ridges Moraine - Summary of Findings:}

The Region directs the Town of Caledon to include, in its Official Plan, policies to prohibit settlement areas outside the Greenbelt to expand into the Greenbelt (2.2.10.4.18) and directs local municipalities to implement and refine the requirements of the Greenbelt (

2.2.10.3.3 and specifically the City of Brampton and the Town of Caledon to bring their Official Plan and Zoning By-law into conformity with the Greenbelt Plan (2.2.10.5.24).

The Town of Caledon was directed to implement the Oak Ridges Moraine Conservation Plan (2.2.9.3.3) and bring its Official Plan into conformity with ORMCP (2.2.9.3.4), and, have all applications for development or site alteration, which commenced on or after November 17, 2001, to conform to the ORMCP (2.2.9.3.3.2).

The Town of Caledon was prohibited from installing new rapid infiltration basins and rapid infiltration columns within the ORMCPA - Oak Ridges Moraine Conservation Plan Area (2.2.9.3.31). And the Region prohibits new or expanded mineral aggregate extraction sites and wayside pits and quarries or any ancillary or accessory uses in the Natural Core Areas as designated within the Oak Ridges Moraine Conservation Plan Area (3.3.2.3)

Lastly, the most restrictive policies will be applied to Peel, except where prohibited by the ORMCP 


\section{Niagara Escarpment}

The Region supports the designations and policies of the Niagara Escarpment Plan (2.2.8.1.1) and requires the Town of Caledon to have policies, in its official plan which conform with the policies of the Niagara Escarpment Plan within the Niagara Escarpment Plan Area (2.2.8.1.2), and prohibits new or expanded mineral aggregate extraction sites and wayside pits and quarries or any ancillary or accessory uses the Escarpment Protection Area of the Niagara Escarpment Plan (3.3.2.3)

\section{Parkway Belt West Plan Area}

2.5.2.5 Encourage the area municipalities to restore and enhance the natural heritage features and functions within the Parkway Belt West Plan Area.

\section{Landform Conservation Area - Summary of Findings}

The Region promotes planning, design and construction practices, which conserve landform, particularly within the Oak Ridges Moraine Conservation Plan Area and the Niagara Escarpment Plan Area, and to protect ecological features, forms and/or functions from the disruption or destruction of landform (2.3.2.21) and directs the Town of $\mathrm{Caledon}$ to require development or site alteration applications in a landform conservation area to carry out construction practices that will keep disturbance to landform character to a minimum as required by the ORMCP (2.2.9.3.18). Lastly, Peel encourages the area municipalities to protect significant landforms, landscapes, vistas and ridgelines, as appropriate $(2.3 .2 .20)$.

\section{Development Policies for Other Areas - Summary of Findings}

2.2.9.3.19 Direct the Town of Caledon to require applicants for development or site alteration with respect to land in a provincially significant Area of Natural and Scientific Interest (Earth Science), or within the associated minimum area of influence, to complete to the Town's satisfaction an earth science evaluation in accordance with Section 30 (12) of the ORMCP. 


\section{Soil - Summary of Findings}

2.1.3.6 Encourage the area municipalities, in consultation with the conservation authorities, to promote and enforce soil conservation measures on developing sites.

\section{Water Related - Summary of Findings}

\section{General}

2.2.6.1.3 Protect, maintain and enhance the quantity and quality of water resources for the supply of potable water and maintenance of ecosystem integrity in Peel.

\section{Fish Habitat}

2.1.3.5 Ensure, jointly with the area municipalities and the conservation authorities in consultation with the Department of Fisheries and Oceans, that no negative impacts, as defined in the Provincial Policy Statement, occur to fish habitat as a result of development and site alterations.

\section{Groundwater}

The Region protects, maintains and enhances the integrity of ecosystems through the proper planning and management of groundwater resources and related natural systems in Peel (2.2.5.1.1) and Work with the area municipalities, conservation authorities and other provincial agencies to protect, maintain and enhance groundwater resources (2.2.5.1.2).

\section{Lake Ontario}

The Region participates in international, national, provincial, inter- regional and area municipal initiatives, including the implementation of the Lake Ontario Greenway Strategy and the preparation and implementation of remedial action plans, to protect and restore the aquatic ecosystem of Lake Ontario and its associated shoreline (2.2.6.1.1).

The Region encourages the City of Mississauga, the conservation authorities and the appropriate agencies to consider an Integrated Shoreline Management Plan for an appropriate segment of the Lake Ontario Shoreline (2.2.6.1.2) and to consider opportunities for natural habitat restoration along the shoreline and within the littoral zone of Lake Ontario (2.5.2.2). 
Lastly, it supports initiatives of the Waterfront Regeneration Trust including the Lake Ontario Waterfront Trail connecting Burlington Bay to the Trent River (3.5.2.5).

\section{Watershed}

The Region determines jointly with the area and neighbouring municipalities, conservation authorities, and other provincial agencies, a schedule prioritizing the need for watershed and subwatershed plans in Peel Region (2.2.4.1.3), the requirements to include in watershed and subwatershed plans (2.2.4.1.4), where planning initiatives are likely to have a significant immediate or cumulative impact on water resources and related natural systems in a watershed or subwatershed, including the Water Resources policies contained in Section 3.4 of this Plan (2.2.4.1.2), to integrate subwatershed planning and monitoring information on a regional and watershed basis, in order to assess the cumulative effects of land use changes and the implementation of subwatershed plans (2.2.4.1.5). In addition, the Region to Integrate ground and surface water quality and/or quantity monitoring conducted by Regional departments with watershed and subwatershed plans and other environmental monitoring, including the analysis of cumulative effects $(2.2 .4 .1 .6)$.

Lastly, The region ensures jointly with the City of Brampton, the Town of Caledon and conservation authorities, that all land use activities related to the post extraction rehabilitation of mineral aggregate operations are consistent with any relevant approved source protection plan and relevant watershed or subwatershed plan $(2.2 .10 .5 .23)$.

\section{Wellhead / Aquifier}

2.2.9.3.20.1 In planning for the Regional Transportation and Road network, the Region will consider, jointly with the Town of Caledon, restrictions on haulage routes for transportation of chenicals and volatile materials in wellhead protection areas and in areas of high aquifer vulnerability.

\section{Activities Restrictions/Uses to protect the Environment:}

5.9.4.2.8 and 5.9.4.2.7 Protect and preserve the natural environment, consistent with the objectives and policies in this Plan, the area municipal official plans, the Environmental Assessment procedures, and if 
applicable, the Greenbelt Plan, Niagara Escarpment Plan, the Oak Ridges Moraine Conservation Plan and the Parkway Belt West Plan where Regional roads are proposed to be widened, reconstructed or improved. Where portions of Regional roads have scenic, environmental, or cultural heritage or archaeological resources, this policy is intended to retain and protect the unique features of the road section. (Adopted ROPA 22)

3.3.2.11 Encourage the area municipalities to develop by-laws under the Municipal Act to regulate the operation of existing peat extraction pits to ensure the adverse impacts on the natural environment are kept to a minimum.

2.5.2.7 Work jointly with agencies and landowners to rehabilitate abandoned extraction areas and progressively rehabilitate operating pits and quarries and peat extraction areas to the highest level of ecological integrity practicable within the context of the area municipal official plans.

2.2.9.3.20.2 Prohibit the construction or expansion of partial services unless the following appropriate circumstances apply: a) To address a serious health concern or environmental concem; b) The construction or expansion of partial services approved under the Environmental Assessment Act before November 17, 2001 provided that the period of time during which the construction or expansion may begin has not expire. c) To service existing uses and new uses that are established in accordance with the Region of Peel Official Plan and Town of Caledon Official Plan within the approved partial service area identified on Figure 14.

\section{Additional Policies:}

2.2.10.5,8 Require that within the Protected Countryside all reasonable efforts be made to keep infrastructure serving the agricultural sector, such as agricultural irrigation systems, out of key natural heritage features or key hydrologic features or the vegetation protection zones.

2.4.2.2.3 Support the City of Mississauga, in conjunction with the conservation authorities, in considering development and site alterations within the regulatory flood standard and/or regulatory erosion standard of the regulatory shorelines only where:

- the flooding and erosion hazard can safely be addressed;

- new or existing hazards are not created or aggravated;

- no adverse environmental effects will result;

- vehicles and people have a way of safely entering and exiting the area during times of flooding and 


\begin{abstract}
Urban forestry program - policy requiring the planting and maintaining of trees specifically to reduce carbon emissions.
\end{abstract}

\section{Energy Conservation}

erosion emergencies; and

- e) development and site allterations are carried out in accordance with established standards and procedures.

2,4.3.2.1 Support, as appropriate, the policies and programs of the conservation authorities related to ravine, valley and stream corridor management and protection.

2.4.3.2.2 Direct the area municipalities, in consultation with the conservation authorities, to include in their official plans policies that support non-structural risk management measures and generally prohibit development and site alterations within the one hundred year erosion limit.

2.4.3.2.4 Discourage the creation of additional tableland within valley and stream corridors.

2.4.3.2.5 Generally prohibit the creation of new lots within valley and stream corridors.

2.5.3.2.1 Acknowledge and support the role of the area municipalities, conservation authorities, provincial agencies and conservation organizations in carrying out invasive species management.

2.5.3.2.3 Encourage the use of native species plantings at Regional and municipal facilities and along transportation and utility corridors and, wherever feasible and appropriate, include native species plantings along Regional roads and on properties owned by the Region.

2.5.2.9 Work jointly with the agencies and area municipalities to develop urban forest strategies and to encourage and support programs and initiatives that maintain and enhance the urban forest canopy.

\section{Summary of Findings}

The Region supports the continued development of Regional and area municipal programs to conserve energy and improve energy efficiency across all sectors (3.7.2.6), and supports energy demand management initiatives by the local municipalities and other agencies to reduce energy consumption and improve energy efficiency through appropriate land use and development patterns that are transit-supportive, site and building designs and promote opportunities for district energy (3.7.2.1). And, it encourages local municipalities to incorporate in their official plans, policies on energy efficient building and landscape design and construction practices, including orienting buildings to maximize the use of solar and wind energy, as well as carrying out building energy audits and retrofits (3.7.2.2).

Peel supports policies that promote the creation of innovative green spaces such as green roofs, white roofs, 
and the use of urban tree canopy to achieve energy efficiencies (3.7.2.3), and encourages local municipalities in conjunction with local distribution companies and other agencies, to implement Provincial and other incentive programs that would reward homeowners and businesses for investing in energy efficient technologies, and reducing consumption $(3.7 .2 .10)$.

The Region works jointly with the local municipalities and the Province to investigate the need, feasibility, implications and suitable locations for solar, wind, and bio-energy projects and to promote local clean energy generation, where appropriate and in accordance with the Green Energy Act. (Provincial Modification) (3.7.2.11) and promotes and advocates for sustained Federal, Provincial, and Municipal incentives and programs that improve energy efficiency and design for housing to Peel residents (5.8.5.2.2). In addition, Peel supports district energy systems such as cogeneration and geothermal systems, where appropriate, to reduce greenhouse gas emissions and air pollution $(3.7 .2 .8)$.

The Region permits uses and activities that are related to the use of renewable resources, in accordance with the Greenbelt Plan and all other applicable legislation, regulations and municipal planning documents, including the PPS in the Protected Countryside $(2.2 .10 .5 .18)$ and promotes alternative or renewable energy generation facilities in the Prime Agricultural Area, and other suitable areas as determined by the relevant area municipality and the Niagara Escarpment Commission. (Provincial Modification) (3.7.2.14). It also encourages the local municipalities to include criteria in their Official Plans and zoning by-laws for evaluating alternative and renewable energy system proposals, including location and land use compatibility. (Provincial Modification) (3.7.2.15)

The Region is to develop (or has already done so) a program to retrofit its owned facilities and buildings and encourages the area municipalities to retrofit their own facilities and buildings (3.7.2.7). It also encourages the increased use of electric, hybrid and alternative fuel vehicles for Regional operations and the Regional fleet, where the production of such fuels, uses waste biomass and does not consume land that would otherwise be used for growing food, and does not conflict with existing and planned uses (3.7.2.9). In addition, The Region jointly with the local municipalities, the Province, hydro utilities and private power generating companies, are studying the potential of broadening the role of the Region to own and/or operate district energy systems $(7.6 .2 .15)$.

Lastly, The Region is or has investigated with the local municipalities, the need to permit the installation of 
Policies to protect and manage water sources and conserve usage of water. individual generating systems as accessory structures to reduce on-site consumption of utility supplied power (3.7.2.12) and promotes individual generating systems as accessory structures in appropriate locations, in consultation with local municipalities and the Niagara Escarpment Commission (3.7.2.13).

\section{Additional Policies:}

5.8.5.2.5 Advocate to the Federal and Provincial government to provide economic incentives and funding for housing projects that have implemented minimum green and sustainable building guidelines to help mitigate the effects of any added financial costs brought by such initiatives.

\section{Summary of Findings:}

The Region is pursuing a water efficiency strategy with a goal to reduce per capita consumption by $10-15 \%$ over the next 20 years (6.3.2.9) and in cooperation with local municipalities, the public and businesses, to pursue water conservation strategies to improve the efficiency of the Region's systems (6.3.2.6). It directs the local municipalities to establish policies and programs to protect, maintain and enhance water resources (3.4.2.4).

Peel initiates, promotes and supports the efforts to further identify, study, analyze and monitor water resources, jointly with the area municipalities, conservation authorities and other related agencies to ensure water quantity and quality meet provincial and regional standards (3.4.2.2) and also supports, as appropriate, coordinated inter- municipal and inter-agency water resources management efforts, particularly with respect to cross boundary resource issues (3.4.2.3).

Peel supports policies that promote water conservation measures and stormwater best management practices to ensure energy conservation (3.7.2.5) and protects vulnerable surface and ground water areas in accordance with provincial policy and the requirements of this Plan (2.2.10.4.11). In addition, it promotes and supports measures to restore or enhance, as appropriate, degraded water resources jointly with the area municipalities, the Province and conservation authorities (7.6.2.16).

The Region works jointly with the area municipalities, conservation authorities and other agencies to determine modifications needed to the official plans, policies and programs of the Region, the area municipalities and the conservation authorities which may be identified through watershed and subwatershed plans and other related studies (7.9.2.5.6). 
The Region protect, maintain and enhance the quality and quantity of water resources, including surface and groundwater systems, jointly with the area municipalities, conservation authorities and other related agencies (3.4.2.1) by directing the local municipalities to require appropriate hydrological and hydrogeological studies be undertaken, to the satisfaction of the Region, the area municipalities and the conservation authorities, for all planning initiatives that may have an immediate or cumulative impact on water resources, when possible these studies should be integrated with subwatershed plans $(3,4,2.6)$, by to establish coordinated procedures with respect to water taking permits (3.4.2.9),

by supporting sound agricultural land management and soil conservation practices, and other measures that minimize or eliminate the amount of pesticides, nutrients, silt and other contaminants which have the potential to enter ground and surface water systems of the region (3.4.2.8), and by promoting strategies intended to reduce and prevent impacts on the environment through appropriate design of the transportation system and, specific to water pollution, the treatment of urban runoff $(5.9 .8 .2 .3)$. In addition, it directs the Town of Caledon to prohibit the approval of major development unless the relevant requirements outlined in Sections 24 (watershed plans), 30 (8) (land conservation plans show all water bodies), 43 (well head protection areas, areas of high aquifier vulenrability), 45 (stormwater management), and 46 (stormwater management plans) of the ORMCP have been satisfied (2.2.9.3.25) and the local municipalities to include in their official plans, objectives and policies for the management of stormwater quality and quantity that would avoid, minimize and/or mitigate storm water volume, contaminant loads and impacts to receiving water courses. $(2.4 .4 .2 .4)$.

The Region has specific policies to protect and manage the aquiñers, Great Lake, groundwater, watersheds, subwatersheds, valley and stream corridors, wetlands, sewage and water infrastructure, wells and wellheads. - these policies are located in excel document.

Energy and Water Conservation Policies:

5.8.5.2.1 Identify and promote, in collaboration with the area municipalities, energy and water efficient technologies in new residential development, redevelopment, and intensification to the development industry.

5.8.5.2.3 Encourage the area municipalities to offer incentives to developers and contractors through planning approvals to implement additional green standards beyond the minimum Ontario Building Code provisions that make homes more energy efficient. 
Green procurement - municipal contracts with environmentally responsible management practices.

\section{Additional Policies:}

2.2.10.5.12 Require, where settlement area expansions are contemplated, the completion or approval of the environmental assessment in support of expanded sewage and water services prior to amending the boundaries of the settlement within the municipal official plan. The expansion must not extend into the Natural Heritage System.

2.2.10.5.17 Direct the City of Brampton and the Town of Caledon to require storm water management plans for applications for development and site alteration in the Protected Countryside. These storm water management plans shall meet the objectives of the Greenbelt Plan and demonstrates that

a) Planning, design and construction practices will minimize vegetation removal, grading and soil compaction, sediment erosion and impervious surfaces;

b) Where appropriate, an integrated treatment approach shall be used to minimize storm water management flows and structures through such measures as lot level controls and conveyance techniques such as grass swales; and

c) Applicable recommendations, standards or targets within watershed plans and water budgets are complied with.

2.4.2.2.2 Support the City of Mississauga, in conjunction with the conservation authorities, in directing development and site alterations to areas outside the Lake Ontario Regulatory Shoreline.

5.9.8.2.5 Increase the number of hybrid and alternative fuel vehicles in the Regional fleet, thereby reducing both the amount of conventional fuel used and the emissions resulting from its use. (Adopted ROPA 22) 6.4.2.6 In partnership with the area municipalities, use procurement as a method to promote source reduction through the significant purchasing power of the Region and the area municipalities.

\section{Summary of Findings}

The Region is to develop (or has already done so) a program to retrofit its owned facilities and buildings and encourages the area municipalities to retrofit their own facilities and buildings (3.7.2.7).

It also encourages the increased use of electric, hybrid and alternative fuel vehicles for Regional operations and the Regional fleet, where the production of such fuels, uses waste biomass and does not consume land that would otherwise be used for growing food, and does not conflict with existing and planned uses (5.9.8.2.5, 3.7.2.9). In addition, The Region jointly with the local municipalities, the Province, hydro utilities and private power generating companies, are studying the potential of broadening the role of the Region to own and/or operate district energy systems (7.6.2.15). 
The Region actively encourages, promotes and supports the efforts of government, the area municipalities the private sector and the general public which reduce waste, or emphasize reuse, recycling, composting and other minimization options including extended producer responsibility (6.4.2.2). Peel has prepared and maintains, in cooperation with the area municipalities, a Waste Management Strategy to achieve the waste management objectives by focusing on reduction, reuse, and recycling programs, and recovering resources of residual waste prior to landfill which may include, but is not limited to, the following measures: $(6.4 .2 .1$, 7.6.2.20)

- reducing adverse impacts of waste to the natural environment;

- integrating the principle and hierarchy of the 3Rs into the decision making of consumers, businesses and governments;

- establishing and maintaining an environmentally responsible and cost-effective system for managing waste;

- establishing targets for the diversion, reduction and potential elimination from landfill of waste within the region, and recommending programs and plans, including financial considerations, for achieving such targets; and

- establishing public education and promotion programs on various concepts of waste management. "

The Region mainly focuses on waste diversion and ways of reusing the waste that was generated although it also uses use procurement as a method to promote source reduction in the purchases that the Region and local municipalities make $(6.4 .2 .6$.

\section{Waste diversion:}

The Region requires new development to comply with the Peel Waste Collection Design Standards Manual to ensure safe and efficient waste collection and diversion through consultation with the area municipalities and applicants. (6.4.2.3), and through the Region"s sewer use by-law, provide education and proper disposal of household hazardous waste which will also reduce the pressure on to the sanitary sewers and sewage treatment plants $(6.3 .2 .8)$.

Peel is also to explore and consider options to address industrial, commercial and institutional waste 
diversion such as mandatory recy cling plans, pay-as-you-throw, and waste hauler reporting programs (6.4.2.17) and consider economic and policy tools for all multi-residential buildings to encourage waste diversion $(6,4.2 .18)$.

\section{Waste Uses:}

Most of the waste management policies identified in the analysis, almost $50 \%$, focused on reusing the waste that was generated and looking for markets, and reusing of construction materials.

Peel is to develop specifications where practical for all Regionally funded projects to incorporate materials from waste diversion programs where viable to help create stable, sustainable markets for materials from Regional diversion programs (6.4.2.7), and encourage local the local municipalities to require developers and contractors to incorporate materials from waste diversion programs into construction projects where practical $(6.4 .2 .8)$.

The Region encourages the local municipalities to issue site approvals and building permits as a means to require materials generated at construction and demolition sites to be diverted and reused (6.4.2.14) and to adopt procurement specifications for maximizing diversion and reuse of construction and demolition waste for all new construction and demolition projects which the area municipalities fund, and to consider economic and other incentives to encourage high reuse of construction and demolition waste (6.4.2.16). Lastly, Peel to develop procurement specifications where possible for all new construction and demolition projects, which the Region funds to maximize diversion and reuse requirements and encourage the reuse of construction materials through economic and other incentives (6.4.2.15).

The Region recognizes energy from waste facilities and other technologies as options for recovering resources from residual waste generated within Peel Region prior to landfill (6.4.2.9). It aims to maximize to the extent reasonably practical, the recovery of resources from the waste stream such as extracting energy from the residual waste stream prior to final disposal (6.4.2.10) and encourages the local municipalities to develop guidelines to permit energy from waste facilities in appropriate locations (6.4.2.13).

The Region to monitor and evaluate technology developments and consider options for recovering energy from waste on an on-going basis (6.4.2.11) and request the provincial government to recognize energy from 
waste as a method of waste diversion to ensure that the maximum resources are extracted from all municipal waste prior to final disposal

(6.4.2.12).

Lastly, The Region requires the local municipalities to permit waste facilities, including processing and storage in appropriate locations so that the policies do not present unreasonable barriers to development of waste facilities (6.4.2.4). Peel to ensure that the location of any new waste disposal management facility is consistent with the objectives and policies in this Plan and the local municipal official plans (6.4.2.5) and considers partnerships with neighbouring municipalities and private industry when exploring the development of new waste management infrastructure as it can lead to a contribution of land, capital, or a commitment to tonnage which will improve the economics of a new facility $(6.4 .2 .19)$.

Note: some of these policies also belong in green procurement.

The Region works with Metrolinx, other Provincial agencies and ministries, area municipalities, and other regions and municipalities in the Greater Toronto and Hamilton Area to implement the Metrolinx Regional Transportation Plan (RTP) and contribute to the ongoing development of the RTP (5.9.2.15), and to promote the use of innovative technologies (e.g. Intelligent Transportation Systems) to improve the efficiency, reliability and safety of the Regional transportation system. (5.9.2.22).

Transportation demand management - policy encouraging the reduction of automobile use through the application of traffic control, public parking and public transit and road strategies.
The Region works with the local municipalities, adjacent municipalities, other levels of government and non-governmental agencies to develop and implement Transportation Demand Management programs to reduce trip distance and time and increase the modal share of alternatives to single-occupant automobiles (5.9.2.12, 5.9.9.2.6). In addition, Peel works with the Greater Toronto and Hamilton Area municipalities, the Province and stakeholder groups to minimize traffic congestion, air pollution and noise pollution from automobiles and other modes of transportation (5.9.8.2.1). York also works with all levels of the public and private sector the Province, area municipalities and adjacent municipalities to provide transportation systems that are safe, sustainable and energy efficient, offer travellers a variety of mobility choices, and encourage the most financially and environmentally appropriate mode for trip-making. $(5,9,2.2)$. York works to develop programs that place primary consideration on the reduction or elimination of trips and the increased use of sustainable modes of transportation and to develop programs for implementing these and other travel demand management strategies (5.9.9.2.3). And encourages efficient fuel use and conservation by promoting Transportation Demand Management programs, linked trips, the use of Intelligent Transportation Systems and the use of public transit and active transportation (5.9.8.2.4). 
Lastly, York works with the Province and local municipalities to support the integration of transportation system planning, land use planning and transportation investment at all stages of the planning process.

(5.9.2.3), and, coordinates, when appropriate, one or more joint planning studies in cooperation with the Region of York, City of Brampton, Town of Caledon and City of Vaughan, to establish mutual long term transportation and transit implementation strategies and servicing infrastructure requirements respecting designated and proposed development in the vicinity of Regional Road 50 in Brampton and Vaughan (7.6.2.19).

The Region optimizes the use of existing and new Regional transportation infrastructure to support growth in an efficient, compact form, and encourages the area municipalities to do the same for infrastructure under their jurisdiction. (5.9.2.5), and when planning for development, York optimizes and/or expands new or existing Regional transportation corridors to support opportunities for multi-modal use, where feasible and to prioritize transit, carpooling, active transportation (5.9.2.7). The Region considers, as part of the development review approval process, the magnitude and timing of development proposals relative to the anticipated transportation demand of the proposed development, and anticipated cumulative transportation effects, on Regional facilities (5.9.2.8) and to identify with the cooperation the local municipalities and the Province, transportation improvements to the provincial, regional and area municipal systems required to support future development or redevelopment, and determine region-wide impacts through comprehensive transportation studies (5.9.2.10).

The Region works with the local municipalities and the Province to develop enhanced tools and techniques for assessing the impacts of new development on sustainable modes of transportation and on transportation demand management measures (5.9.2.9) and to encourage local municipalities to (5.9.9.2.1):

- Promote land uses and site design which foster the use of sustainable modes of transportation

- Promote infrastructure to encourage teleworking;

- Promote a balance of jobs and housing in communities to reduce the need for long distance commuting; and

- For new development in designated greenfield areas, create street configurations, densities and an urban form that support walking, cycling and the early integration and sustained viability of transit services and create high quality public open spaces with site design and urban design standards that support opportunities for transit, walking and cycling.

In addition, The Region to encourage school boards to select school site locations, define catchment areas 
and design school campuses to maximize walking and bicycling as the primary means of travel to school $(5.9 .10 .2 .7)$.

The Region also focuses on carpool lots, High Occupancy Vehicle, Lane Network Lane, multi-purpose reserved lanes, parking management, widening, improving or building roads with transit in mind, improving existing transit and providing buses that can carry bicycles.

Car Pool Lots:

5.9.3.2.8 Encourage the Ontario Ministry of Transportation and 407 ETR to develop and enhance carpool lots at interchanges along major freeways and highways.

5.9.9.2.2 Work with the Province, area municipalities and the private sector to plan and implement a network of carpool parking lots in Peel Region.

High Occupancy Vehicle Lanes and Lane Network:

5.9.4.2.14 Work with the area municipalities, adjacent municipalities and the Province to study the feasibility of developing an arterial High Occupancy Vehicle (HOV) system in Peel to complement the Province's freeway HOV system.

5.9.5.2.5 Encourage transit-supportive measures on major roads and highway corridors in Peel through the use of HOV lanes, Bus Rapid Transit (BRT) and granting preferential treatment to transit, when and where necessary and justified.

5.9.3.2.9 Encourage the Ontario Ministry of Transportation to continue to study and implement the a High Occupancy Vehicle, Lane Network Plan for the 400-Series Highways in the Greater Golden Horseshoe and to update the plan in cooperation with regional and local municipalities.

5.9.4.2.13 Support the efforts by Metrolinx to study the development of an interconnected regional network of multi-purpose reserved lanes that build on existing plans for High Occupancy Vehicle (HOV) lanes to improve the efficiency of highways and arterial roads for transit and multi-occupant vehicles.

Parking Management:

5.9.9.2.7 Encourage area municipalities, local Transportation Management Associations and the private sector to develop parking management strategies that make more efficient use of parking resources and that encourage the use of sustainable modes of transportation.

5.9.9.2.8 Encourage area municipalities to update their parking and zoning by-laws to support and facilitate 
transportation demand management measures.

5.9.9.2.9 Encourage parking operators at mobility hubs, major transit station areas and major commercial and employment areas to provide priority spaces for carpool and car-share vehicles.

Roads with Transit in Mind:

5.9.4.2.5 Protect the designated Regional road rights-of-way, as shown on Schedule F, to accommodate future road widenings and improvements consistent with Section 7.7 of this Plan. Protect additional rightsof-way where necessary to provide for turning lanes or transit related improvements at the intersection of all designated rights-of-way. The wider rights-of-way at either side of the intersection shall be within 350 metres (1150 feet) of an intersection.

5.9.4.2.16 Ensure that new or improved Regional roads support the viability of existing or planned rapid transit services and encourage the area municipalities to do the same for roads under their jurisdiction.

Transit Improvements and Developments:

5.9.5.2.13 Support gateways and interconnections between the local bus network and future transitways, especially at Urban Growth Centres and other mobility and transportation hubs.

5.9.5.2.1 Support the implementation and protection of rapid transit corridors, as shown on Schedule G, as well as those additional higher order transit, bus rapid transit or priority transit corridors proposed on

Regional roads by the area municipalities or Provincial transit authorities. Any changes to rapid transit corridors shown on Schedule $G$ will require an amendment to this Plan.

5.9.5.2.14 Support improved transit connectivity to Toronto - Lester B. Pearson International Airport and the surrounding employment area.

5.9.5.2.15 Support the efforts by Metrolinx to implement a GTHA-wide integrated transit fare system. 5.9.3.2.3 Work cooperatively with the Province and other GTA and Golden Horseshoe municipalities in planning and implementing freeway and higher order transit improvements to be identified in the Growth Plan for the Greater Golden Horseshoe (e.g. East-West Transportation Corridor). This policy (ROPA 16 Policy 5.6.3.2.5) is under appeal to the Ontario Municipal Board.

5.9.5.2.7 Work with Metrolinx and the area municipalities to implement the GO Transit rail and bus service improvements described in the Metrolinx Regional Transportation Plan, and in particular:

a) To provide all-day two-way GO commuter rail service on the Milion and Georgetown lines as soon as possible;

b) To expedite the identification and protection of a new GO Rail station site in Bolton and the 
provision of GO commuter rail service to and from this station

c) To improve the frequency of service on the Lakeshore, Georgetown and Milton GO commuter rail lines;

d) To provide increased inter-municipal/inter-regional express $\mathrm{GO}$ bus service in corridors where there is sufficient demand; and

e) To itmprove connections to Toronto - Lester B. Pearson International Airport from Peel.

5.9.5.2.2 Work with Metrolinx, other Provincial agencies and ministries, the area municipalities and adjacent municipalities in the planning and mplementation of an inter-regional transit system.

5.9.5.2.4 Support the coordination of inter-municipal and inter-regional transit services.

5.9.5.2.6 Support Metrolinx and the area municipalities in the expeditious planning, and implementation of, and support Metrolinx and the federal government in the expeditious funding of, a GTHA-wide rapid transit network and, in particular, of:

a) Rapid transit projects in Peel included in the Metrolinx Regional Transportation Plan; and

b) Rapid transit projects in the City of Mississauga and the City of Brampton not included in the

Metrolinx Regional Transportation Plan.

5.9.5.2.19 Encourage the area municipalities and Metrolinx to provide transit vehicles that can efficiently and easily carry bicycles.

5.9.5.2.12 Support Metrolinx and the area municipalities in:

a) The development of a network of mobility hubs (as identified in the Metrolinx Regional Transportation Plan) and other transportation hubs (as identified by the area municipalities and the Region);

b) Promoting transit stations and terminals in urban nodes and corridors, as identified in this Plan and the area municipal official plans; and

c) The integration of transportation modes at these hubs.

5.9.5.2.3 Support the provision of transit services to rural communities by the Province, area municipalities and/or privately run transit services, where feasible.

\section{Monitor TDM}

5.9.2.17 Work with the Province and other levels of government to improve the coordination and standardization of transportation data collection, forecasting and modelling to support transportation projects and to support the development of performance measures.

5.9.9.2.4 Work with the area municipalities, local Transportation Management Associations and school 
boards to evaluate and measure the progress of TDM programs and to develop new innovative strategies and initiatives.

\section{Additional Policies:}

5.9.2.11 Ensure, in accordance with the requirements of the Region and the area municipalities, that development only proceed with adequate existing or committed improvements to regional transportation capacity and, if necessary, development be phased until that capacity is or will be available.

Bicycle access plan - policies with an integrated plan of bicycle trails, bike lanes and road crossing which is incorporated with the transit support development and transit demand management

\section{Public education on} unsustainable practices and the environment - public awareness and education of the impact

GGH consumption patterns has on the environment and lives of those in distant lands.
5.9.10.2.1 Work with Metrolinx, the area municipalities and adjacent municipalities to integrate pedestrian and bicycle networks into transportation planning to:

a) Provide safe, comfortable travel for pedestrians and bicyclists within unities and new development; and

b) Provide linkages between intensification areas, adjacent neighbourhoods and transit stations. 5.9.10.2.2 Work with Metrolinx, the area municipalities, adjacent municipalities and the private sector to develop and implement an Active Transportation Plan for Peel that builds on area municipal pedestrian and cycling plans.

5.9.10.2.4 Encourage the area municipalities to promote land uses which foster and support the use of active transportation.

5.9.10.2.5 Work with the area municipalities to develop performance indicators for the implementation and usage of active transportation and use these indicators to monitor the impact and effectiveness of the active transportation plan.

\section{Social Development}

\section{Affordable Transit}

Cooperative housing - land use provisions that permit multifamily housing development in which residents have both private and shared spaces under

\section{None}

\section{Summary of Findings:}

No policies were identified as specifically addressing provisions for cooperative housing although policies to provide housing options to a diverse population based on their preferences and values $(5.8 .6 .2 .9$, 5.8.6.2.10) are offered in Peel.

5.8.6.2.3 Encourage the area municipalities to review their requirements for minimum distance and 


\begin{tabular}{|c|c|}
\hline $\begin{array}{l}\text { cooperative ownership and } \\
\text { management. }\end{array}$ & $\begin{array}{l}\text { maximum number of boarding houses, group homes, lodging houses, rooming houses, and other similar } \\
\text { types of homes to ensure a range of housing options. } \\
5.8 .6 .2 .8 \text { Encourage and facilitate the development of partnerships among housing providers, service } \\
\text { providers, community organizations and other stakeholders to provide special needs housing and related } \\
\text { services. } \\
5.8 .6 .2 .9 \text { Develop, in collaboration with the area municipalities, measures to provide opportunities to meet } \\
\text { the housing needs of diverse populations. } \\
5.8 .6 .2 .10 \text { Consider preferences and values of diverse populations in the design and construction of social } \\
\text { housing. }\end{array}$ \\
\hline $\begin{array}{l}\text { Affordable Housing - zoning } \\
\text { regulations that encourage or } \\
\text { require the provision of lower } \\
\text { cost housing. }\end{array}$ & $\begin{array}{l}\text { York promotes and pursues Federal and Provincial incentives for Regionally funded housing projects to } \\
\text { help support the Region's sustainability goals (5.8.5.2.4) and advocates to the Province to explicitly provide } \\
\text { municipalities the authority to use inclusionary zoning as a tool to require affordable housing }(5.8 .3 .2 .5) \text {. } \\
\text { The Region encourages residential development, redevelopment and intensification to include an affordable } \\
\text { housing component by promoting incentives or funding from different levels of government (5.8.3.2.11), } \\
\text { encourages and supports local municipalities in creating and maintaining appropriate opportunities for the } \\
\text { provision of affordable housing, including social and special needs housing }(6.2 .2 .13) \text {, providing and } \\
\text { maintenance of an adequate supply of affordable rental and ownership housing to meet the diverse needs of } \\
\text { all Peel residents, in partnership with the area municipalities, non-profit and private providers, and through } \\
\text { the effective use of all available and appropriate affordable housing programs and housing rehabilitation } \\
\text { funding sources (6.2.2.17). } \\
\text { York to develop a Peel Housing Strategy in collaboration with the local municipalities and appropriate } \\
\text { stakeholders, which will include affordable, social and special needs housing components. This strategy } \\
\text { should include a component on advocacy to promote housing issues and to address housing needs } \\
\text { (6.2.2.14), an implementation plan with priorities and timeframes among various housing needs of } \\
\text { residents, and, programs and actions to address these needs (5.8.2.7), a monitoring system to evaluate } \\
\text { activities undertaken in support of the Regional Housing Strategy so that they can be revised on an ongoing } \\
\text { basis as the housing needs of Peel residents change (5.8.2.8). Lastly, the Region to evaluate the need to } \\
\text { update the Regional Housing Strategy in conjunction with future Regional Official Plan reviews (5.8.2.9). }\end{array}$ \\
\hline
\end{tabular}


The Region encourages and supports the local municipalities to plan for a range of densities and forms of housing affordable to all households, including low and moderate income households, which will enable all Peel residents to remain in their communities (5.8.2.3), to construct and retain rental housing (5.8.2.5) and to establish minimum new housing unit targets that are affordable in secondary plans where appropriate, to ensure a diverse mix of housing type and tenure (5.8.2.10) and to implement the annual minimum new housing unit targets (5.8.2.13) and through the use of various initiatives, including the Region of Peel Municipal Housing Facility By-law, in partnerships with the private and non-profit housing sectors develop and implement new affordable housing (6.2.2.16). The Region to collaborate with the local municipalities to implement the annual minimum new housing unit targets, they are set at $17 \%$ for social housing, $3 \%$ for affordable rental, $35 \%$ for market rental and affordable ownership and $45 \%$ for market ownership (5.8.2.12). The Region plans to review and update, jointly with the local municipalities, the annual minimum new housing unit targets as defined in policy 5.8.2.12 (5.8.2.14), and maintain, monitor, evaluate and refine the centralized waiting list for all social housing units in Peel Region (6.2.2.11).

York to implement Regional guidelines requiring the incorporation of universal accessible features in existing and new Regionally funded or managed affordable housing development (5.8.6.2.7 and to work with local municipalities to explore opportunities to coordinate the fast-tracking of planning approvals for affordable housing projects $(5.8 .3 .2 .2)$.

York encourages the local municipalities to develop official plan policies with criteria to prohibit the demolition of existing residential rental units without replacement of the same or higher number of residential rental units $(5.8 .4 .2 .2)$ and with criteria to regulate the conversion of residential rental to ownership units $(5.8,4.2 .1)$.

The Region to facilitate the provision of rent-geared-to income components within housing program initiatives and develop a plan for the allocation of rent-geared-to income subsidies (6.2.2.18) and the development of new and improved income supports for households affected by economic housing barriers (5.8.7.2.4)

The Region encourages community agencies and landowners of suitably sized sites to develop affordable housing

(5.8.3.2.12), and, the local municipalities to give priority to sell or lease surplus municipal properties for the development of affordable housing while ensuring the goals, objectives and policies of this Plan and the 
Public education on unsustainable practices and the environment local municipal official plans are adhered to $(5.8 .3 .2 .10)$. The Region to give priority to the development of affordable housing on surplus Regional municipal property while ensuring the goals, objectives, and policies of this Plan and the local municipal official plans are adhered to $(5,8,3,2.9)$.

York to assist public agencies at the federal, provincial, regional and area municipal levels in identifying and maintaining an inventory of available public lands and buildings suitable for housing for low and moderate income households in Peel Region (5.8.2.4) and request developers of affordable housing, including social and special needs housing, and their funding partners to consult with the Region and area municipalities when making locational decisions, to ensure an appropriate and equitable distribution of affordable housing throughout Peel $(6.2 .2 .12)$.

The Region encourages local municipalities to develop alternative development and design standards, where appropriate, to encourage affordable housing development. Examples include reduced setbacks, narrower lot sizes, reduced road allowance, cash-in-lieu of parking, reduced parking standards, and on-street parking (5.8.3.2.3). In addition, the Region to explore, in collaboration with the local municipalities, the feasibility of implementing incentives such as waivers, deferrals or grants in-lieu of development charges, other municipal planning and building fees and charges, and regional property taxes to promote the development of affordable housing (5.8.3.2.1) and to promote secondary suites through the development of educational brochures and information (5.8.3.2.8). York encourages the local municipal official plans to permit secondary suites in new residential development, redevelopment and intensification while ensuring compliance with provincial legislation, plans and municipal standards $(5.8 .3 .2 .6,5.8 .3 .2 .7)$ and. Lastly, York to ensure that future development of Regionally funded affordable housing be located in support of developing compact, complete communities throughout Peel to allow for more transportation options with improved access to services and amenities (5.8.7.2.2).

2.2.3.3.4 In consultation with area municipalities and other levels of government, develop outreach programs to promote air quality and to encourage behaviour change in order to reduce air pollution. 2.2.3.3.5 Proactively engage all levels of government and the private sector to promote more health protective emissions standards for vehicles, industries and energy producing facilities.

2.6.2.6 Encourage environmental education to support land stewardship and to promote the value of natural heritage conservation to residents.

3.7.2.4 Promote public awareness and education initiatives jointly with the area municipalities and other relevant agencies, on matters related to energy conservation. 
5.8.2.11 Work with area municipalities to educate the general public about the need for and benefits of compact housing development and residential intensification.

5.8.7.2.1 Identify actions based on a broad collaborative approach with stakeholders and encourage all levels of government to address and remove barriers through various means, including public education strategies.

5.8,7.2.5 Encourage and facilitate a greater community awareness of key issues related to socio-economic housing barriers. (Adopted ROPA 23)

5.9.2.23 Work with the Province and area municipalities to encourage increased public and business awareness of activities and actions which will lead to increased use of sustainable transportation alternatives. (Adopted ROPA 22)

5.9.8.2.2 Work with the Province, the area municipalities, school boards, transit providers and non-profit organizations, to educate the public, through new initiatives, on the relationship between vehicles, air pollution and impacts on the natural environment. (Adopted ROPA 22)

5.9.9.2.5 Work with the area municipalities, other levels of government, school boards and the private sector to develop and support outreach and marketing programs to that promote sustainable transportation alternatives, such as active transportation and transit, to affect changes in peoples' travel behaviour and to encourage increased use of these alternatives. (Adopted ROPA 22)

5.9.10.2.6 Work with school boards and the private sector to promote the use of active transportation by students and to support the Peel Safe and Active Routes to School program. (Adopted ROPA 22)

6.2.2.21 Promote public awareness and understanding of human services issues to address all related needs. (not sure what to do with this policy, definition of human services, see section 6.2 in ROP)

6.3.2.8 Reduce loads to the sanitary sewers and sewage treatment plants through the Region's sewer use by-law, education and the proper disposal of household hazardous waste

2.2.3.3.3 Raise awareness of local air quality issues and climate change through partnerships with all levels of government and the private sector.

\section{Summary of Findings:}

Most of the 13 policies identified to raise public awareness on unsustainable practices and the environment were focused on sustainable and active transportation $(5.9 .2 .23,5.9 .9 .2 .5,5.9 .10 .2 .6)$, followed by protecting natural environment (2.6.2.6) and understanding air pollution and impact on the natural environment $(2.2 .3 .3 .4,2.2 .3 .3 .5,5.9 .8 .2 .2,2.2 .3 .3 .3)$ and on the social barriers to affordable housing $(5.8 .7 .2 .1,5.8 .7 .2 .5)$. The remaining four policies were distributed among energy conservation (3.7.2.4.), 
Adaptive and mitigative policies to protect urban communities from climate change the need for intensification and compact communities (5.8.2.11), on the proper disposal of household hazardous waste in order to reduce the load placed on the sanitary sewers and sewage treatment plants (6.3.2.8) and climate change (2.2.3.3.3).

The Region to prepare in consultation with the Conservation Authorities, the area municipalities, and stakeholders, a climate change strategy to address both mitigation and adaptation aspects of climate change, including the establishment of targets, policies and programs, to reduce the effects of climate change and minimize adverse impacts (7.6.2.3). In addition, Peel in consultation with the area municipalities, develop tools to assess the air quality implications of development that minimize adverse human health effects. These tools would be applied to but not limited to development applications and projects that may be insignificant by themselves, but cumulatively are significant $(2.2 .3 .3 .1)$ and to prepare and adopt guidelines as appropriate for evaluating selected climatic and air quality impacts of this Plan (7.6.2.7)

Peel to establish corporate targets for greenhouse gas emissions and air pollution reductions to improve local air quality and address climate change (2.2.3.3.6)

Last, Peel to direct the area municipalities, in consultation with conservation authorities, to identify the lands subject to flooding hazards, in the appropriate planning documents, and in their official plans formulate objectives and policies for these lands (2.4.4.2.1).

5.8.7.2.3 Encourage and facilitate the involvement of service providers, community organizations and stakeholders to address identified issues related to housing barriers.

5.9.7.2.2 Establish strong partnerships with public and private stakeholders to develop a vision for goods movement in Peel, determine priorities, and implement action plans for advancing a sustainable goods movement system in Peel.

7.3.5.2.1 Provide opportunities for public consultation on regional issues.

7.3.5.2.3 Investigate more effective ways to consult with the public on planning matters.

7.6.2.21 Work jointly with the area municipalities and other relevant agencies to prepare guidelines and/or protocols regarding public consultation on Regional initiatives.

7.3.5.2.4 Consult with First Nations on land use planning matters in order to create healthy and sustainable 


\section{Summary of Findings:}

The Region to provide opportunities for public consultation on regional issues $(7.3 .5 .2 .1)$, investigate more effective ways to consult with the public on planning matters (7.3.5.2.3) and work jointly with the area municipalities and other relevant agencies to prepare guidelines and/or protocols regarding public consultation on Regional initiatives (7.6.2.21). Peel to consult with First Nations on land use planning matters in order to create heal thy and sustainable regional communities $(7.3 .5 .2 .4)$ and to encourage and facilitate the involvement of service providers, community organizations and stakeholders to address identified issues related to housing barriers (5.8.7.2.3). Lastly, it plans to establish strong partnerships with public and private stakeholders to develop a vision for goods movement, determine priorities, and implement action plans for advancing a sustainable goods movement system in Peel (5.9.7.2.2). 


\section{Policy Strategies / Areas}

\section{Economic Sustainability}

Policies which recognize boundary lines/boundaries around the following communities and areas in the region:

Urban Growth Boundary policies establishing lines around a community/region and the application of zoning regulations that restrict urban development to the areas inside the line.

\section{Urban Areas/Growth Centres - General}

Expansions:

5.1.12. That expansions of the Urban Area, identified on Map 1, shall only be initiated by the Region, in consultation with local municipalities, as part of a municipal comprehensive review that is consistent with the policies of the Places to Grow: Growth Plan for the Greater Golden Horseshoe and the following:

- Population and employment forecasts for the Region;

- The role of the lands proposed for expansion in the context of local municipal growth management;

- The protection of and integration with the Regional Greenlands System;

- The amendment is large enough (e.g. a concession block) with clear and identifiable boundaries, such as concession streets, major natural features, rail or major utility corridors;

- The role of the lands proposed for expansion that is supportive of the Region's urban structure of centres and corridors;

- The completion of local municipal strategies and policies to phase in and achieve the intensification targets in this Plan; and,

- Other policies of this Plan.

5.1.13. That the land area requirements for the urban expansion have been identified as part of York Region's land budget exercise and do not require an additional comprehensive review. The Region will work with the Town of East Gwillimbury, the Town of Markham and the City of Vaughan to 
finalize the land budget and to identify the preferred amount, location and phasing of Urban Area boundary expansions prior to the adoption of local official plans. Update: This policy proposed to be deleted with the proposed amendments to ROP to expand boundaries on Whitebelt lands in East Gwillimbury, the Town of Markham and the City of Vaughan to accommodate the 2031 forecasted population and employment growth (York Land Budget).

5.4.22. That secondary plans may include additional lands located adjacent to the boundaries of urban growth centres, on the basis that such lands have an important supportive or transitional role to the Regional Centres in terms of community compatibility, building forms, land uses and connectivity.

2. Regional Greenland System: (2.1.6) Refinements to the boundaries may occur through periodic updates by the Region which will not require an amendment to this Plan. (this policy covers expansions).

3. Employment lands (4.3.3) The Region requires local municipalities to designate and protect employment lands in local municipal official plans (4.3.2).

4. Strategic employment lands (4.3.4) - To protect strategic employment lands, as identified in Figure 2, including lands bey ond the planning horizon of this Plan. Strategic employment lands are identified based on their proximity to existing or planned 400 -series highways. Strategic employment lands should be identified and protected in local municipal official plans.

5. The size of the ancillary use in the employment lands (4.3.11) - To require local municipalities to determine the location, amount and size of ancillary uses on employment lands that is commensurate with the planned function, size and scale of the overall employment land area.

6. Regional centers (5.4.19 and 5.4.21):

5.4.19. The Regional Centres, identified on Map 1.

5.4.21. That local municipalities shall designate the boundaries of the Regional Centres in Markham, Newmarket, Richmond Hill and Vaughan in a manner generally consistent with the boundaries of the urban growth centres as identified by the Province, and prepare secondary plans consistent with policy 5.4.6 (smart development, energy/water conservation, for each Regional Centre.

7. Regional corridors (5,4.29 and 5.4.30)

- That the Regional Corridors shown on Map 1 shall be designated in local official plans. - 5.4.30. That the boundaries of the Regional Corridors be designated by the local municipality, 
based on:

- Reasonable and direct walking distances between the Regional Corridor street frontage and adjacent lands;

- Contiguous parcels that are desirable and appropriate locations for intensification and mixed-use development; and,

- Compatibility with and transition to adjacent and/or adjoining lands.

Expansions:

5.4.35. To consider extensions to existing Regional Corridors, and the designation of new Regional Corridors, in consultation with local municipalities and based on the following:

- the status and function of existing Regional Corridors;

- opportunities for the extension of well-planned and transit- supportive intensification; and,

- the introduction of new or expanded rapid transit services to Regional streets.

8. Local centers and corridors in Urban Area (5.5.2) - To require local official plans to identify and designate the location of Local Centres and Corridors within the Urban Area.

9. Local centers (5.5.3) - That local municipalities shall address in secondary plans or other appropriate studies the following criteria for Local Centres: $\mathbf{a}$. that the specific location and boundaries of the Local Centres are identified;

10. Towns and Villages (5.6.17) - That the boundaries of Towns and Villages identified on Map 1 of this Plan shall be defined within local official plans.

Expansions:

5.6.19. That within the Greenbelt Plan Area modest expansion of the outer community plan boundary of the Towns and Villages can only be considered at the timing of the review of the Greenbelt Plan, subject to:

- The availability of municipal water and wastewater service;

- The availability of lands within the community plan boundary;

- The expansion does not extend into the Specialty Crop Areas or the Natural Heritage System of the Protected Countryside;

- Other applicable policies of the Greenbelt Plan; and,

- The urban boundary expansion policies in Section 5.1 (Forecasting and Phasing Growth) of this Plan.

5.6.20. (also applies to development) That new development areas within Towns and Villages, be 
subject to comprehensive secondary plans based on the following:

- water and wastewater services are available;

- the plan considers the entire Town or Village and integrates the development into the existing community;

- best efforts to achieve a minimum density requirement of 50 residents and jobs combined per hectare in the developable area;

- best efforts are made to incorporate policies 5.6.4 through 5.6.16 (new community areas prioritize people, sustainability,

- and livability) of this Plan; and,

- best efforts to encourage development within the built-up area of the Towns and Villages that is consistent with the appropriate policies in Section 5.3 (intensification) of this Plan.

11. The Commercial Core in the local centers located in the Towns and Villages (5.6.21) - That Local Centres located within Towns and Villages should identify the area of the commercial core;

12. Hamlets (5.6.2.2 and 5.6.2.8):

5.6.22. That local official plans and zoning by-laws shall designate the boundaries of Hamlets. Expansions:

5.6.31. That notwithstanding policy 5.6.24 (major development shall not be permitted), additional growth and development in the Hamlet of Vandorf in Whitchurch-Stouffville may be permitted in conformity with the Vandorf Preston Lake Secondary Plan, when approved, and an appropriate water and wastewater solution.

5.6.29. That where Hamlets occur in new community areas, growth in the Hamlet shall be coordinated with new community development on the surrounding lands to permit the orderly extension of municipal services to the Hamlet.

5.6.28. That local municipalities may undertake minor rounding out of Hamlet boundaries in accordance with the Greenbelt Plan and the Lake Simcoe Protection Plan.

13. Greenbelt Area Protected Countryside (6.1.1) - That lands within the Greenbelt Plan are identified as Protected Countryside on Map 1 of this Plan. While the Greenbelt Plan includes the Oak Ridges Moraine Conservation Plan Area, the policies of the Oak Ridges Moraine Conservation Plan prevail in the area of its coverage.

14. Oak Ridges Moraine (6.2.1 and 6.2.3)

6.2.1. To recognize the boundary and land use designations of the Oak Ridges Moraine Conservation Plan Area as shown on Map 1. 


\section{Policies which restrict urban development to the areas inside the line (developments and uses):}

6.2.2 The Urban Area is intended to be the focus of growth. These areas permit a full range of residential, commercial, industrial, and institutional uses. Small-scale industrial, commercial, institutional and recreational uses shall be directed to Hamlets, Towns and Villages and the Urban Area.

5.1.8. To require, within each local municipality, that a phase of new community area development is substantially complete (i.e., generally $75 \%$ of residential land area built) before a subsequent phase may be registered, to ensure the orderly development of land.

5.2.19. That the policies of this Plan are supported by the Guidelines for Community Development in York Region. New development shall meet all required items, and be encouraged to achieve all optional items.

The guideline document shall be amended from time to time without amendment to this Plan

5.3.14. That intensification areas be planned to avoid special policy areas unless there exists no other alternatives outside of the floodplain.

5.3.6. That intensification areas be planned and designed to achieve an appropriate transition of built form to adjacent areas.

5.4.3. To recognize that the Regional Centres and Corridors form part of a larger regional system of urban growth centres and intensification corridors, which are vital to the long term prosperity and identity of communities within the Greater Toronto and Hamilton Area.

5.6. 8. That new community areas shall be planned to consider human services needs, including educational, social, health, arts, culture, and recreational facilities.

\section{Employment lands, Strategic employment lands, Ancillary use}

Ancillary Uses:

4.3.10. To allow a limited amount of ancillary uses on employment lands, provided that the proposed use is designed to primarily service businesses in the employment lands and that ancillary uses collectively do not exceed $20 \%$ of total employment in the employment land area.

4.3.12. That local municipalities exclude land uses other than employment and ancillary uses on Local Corridors and other major streets within and/or adjacent to employment lands.

$4.3 .6 \mathrm{~b}$. Uses not permitted on employment lands include residential, major retail and non-ancillary uses. 
4.3.11. To require local municipalities to determine the location, amount and size of ancillary uses on employment lands that is commensurate with the planned function, size and scale of the overall employment land area.

Land Conversion:

4.3.6. That the conversion of employment lands to non-employment land uses is not permitted. For the purposes of this policy:

- Employment lands are lands that are designated for employment uses including land designated as industrial and business park in local official plans; and,

- Uses not permitted on employment lands include residential, major retail and non-ancillary uses. 4.3.7. That notwithstanding policy 4.3.6, the conversion of employment lands to non-employment land uses may be considered, together with local municipalities, provided that a Regional municipal comprehensive review has been completed in accordance with the applicable policies, forecasts and land budget of the Region.

4.3.8. That the conversion of employment lands within Regional Centres and key development areas along Regional Corridors do not require a municipal comprehensive review for mixed-use development that supports the policies contained in Section 5.4 (Building Complete Communities - Regional Centres and Corridors) of this Plan.

4.3.9. To require local municipalities to include employment land non- conversion policies within local official plans and secondary plans that are consistent with policies of the Province and the Region.

Protect Lands:

4.3.3. To require local municipalities to designate and protect employment lands in local municipal official plans.

4.3.4. To protect strategic employment lands, as identified in Figure 2, including lands beyond the planning horizon of this Plan. Strategic employment lands are identified based on their proximity to existing or planned 400 -series highways. Strategic employment lands should be identified and protected in local municipal official plans.

4.3.5. To require local municipalities to give priority to strategic employment lands when considering additional employment land designations. 


\section{Other:}

4.3.22. That the employment land designation policies in ROPA 52 (Highway 400 North Employment Lands Secondary Plan Study) continue to apply.

4.4.6 That major retail is not permitted on designated or strategic employment lands

4.4.8 To work with local municipalities to identify and designate lands for major retail that is integrated within the community.

\section{Regional centers}

5.4.19. That the Regional Centres will contain a wide range of uses and activities, and be the primary focal points for intensive development, that concentrates residential, employment, live-work, mobility, investment, and cultural and government functions.

5.4.20. That the planning and implementation of Regional Centres will provide: $a$. the greatest intensity of development within the Region;

5.4.27. To co-ordinate and work with the Towns of Markham and Richmond Hill, and the neighboring City of Vaughan, in the planning and implementation of the secondary plans for the Richmond Hill/Langstaff Gateway Centre, to achieve a complete and integrated Regional Centre. 5.4.32. That secondary plans, consistent with criteria in policy 5.4 .6 , shall be prepared by local municipalities for the following key development areas:

- All planned subway stations outside of the Regional Centres;

- Lands immediately adjacent to transit terminals, including GO Transit terminals and gateway hubs; and,

- Other key development areas identified by local municipalities."

\section{Regional Centers and Corridors}

3.3.3. To direct the location of major human service facilities to Regional Centres and Regional Corridors.

4.4.4. To direct a significant amount of mixed-uses, including street-related retail, to Regional Centres and Corridors.

5.4.1. That the Regional Centres and Corridors serve a critical role as the primary locations for the most intensive and greatest mix of development within the Region.

5.4.11. That Regional Centres and Corridors shall be considered as the primary locations for public 
facilities and services such as government of fices, educational institutions, and hospitals.

5.4.12. To prepare, in consul tation with local municipalities, a comprehensive and innovative suite of implementation guidelines for the Regional Centres and Corridors. The guidelines will address:

- Transit-oriented development;

- Urban design and built form;

- Parking management;

- Affordable housing; and, e. financial and planning instruments. "

4.2.7. To ensure the efficient movement of goods and services in Regional Centres and Corridors through effective planning, urban design and infrastructure planning.

\section{Regional Corridors}

5.4.30. That the boundaries of the Regional Corridors be designated based on contiguous parcels that are desirable and appropriate locations for intensification and mixed-use development.

5.4.31. That the most intensive and widest range of uses within the Regional Corridors be directed to specific intensification areas, identified by local municipalities as key development areas. These areas shall include the following segments of the Regional Corridor:

- Lands within a reasonable and direct walking distance from all planned subway stations, and select rapid transit stations as identified by local municipalities;

- Major transit station areas immediately adjacent to transit stations and terminals, including GO Transit; and,

- Large and/or contiguous properties that are under-utilized, and are appropriate and desirable locations for redevelopment or intensification.

5.4.28. That Regional Corridors are planned to function as urban main streets that have a compact, mixed-use, well-designed, pedestrian-friendly and transit-oriented built form.

\section{Local Centres and Corridors}

4.3.12. That local municipalities include official plan and secondary plan policies and zoning provisions to exclude land uses other than employment and ancillary uses on Local Corridors and other major streets within and/or adjacent to employment lands.

5.5.1. That local centres and corridors serve as important neighborhood focal points and main streets that provide a range of employment, shopping, recreation, human services and housing opportunities 


\section{Towns and Villages}

5.6.21. That Local Centres located within Towns and Villages should meet the following criteria, in addition to the policies of Section 5.5 (Building Complete Communities - Local Centres and Corridors) of this Plan:

- Identify the area of the commercial core;

- Protect the significant natural features of the community such as rivers, lakes, etc.;

- Recognize the potential for commercial and tourist activity;

- Recognize the servicing capacity of the community; and,

- Provide human services for surrounding rural and agricultural areas. "

5.6. 18. That the local community plans for Towns and Villages may also include rural and agricultural designations within their boundaries. Any redesignation of agricultural and rural uses within the local community plan boundary to urban uses are subject to the provisions of policy 5.1.12 (That expansions of the Urban Area shall only be initiated by the Region, in consultation with local municipalities, as part of a municipal comprehensive review that is consistent with the policies of the Places to Grow: Growth Plan for the Greater Golden Horseshoe and the selected policies of this Plan).

6.2.2 The Urban Area and Towns and Villages are intended to be the focus of growth. These areas permit a full range of residential, commercial, industrial, and institutional uses.

\section{Hamlets}

5.6.22. That local official plans and zoning by-laws shall designate the boundaries of Hamlets and provide policies that limit future growth to minor infilling, subject to the ability to service growth by individual private on-site water and wastewater systems.

5.6.23. That limited small-scale industrial, commercial and institutional uses may be permitted in local official plans, subject

to the ability to service the growth by individual private on-site water and wastewater systems. 5.6.25. That consents may be permitted in Hamlets, subject to local official plan consents policies and the ability to service the development by individual private on-site water and wastewater systems.

6.2.2 Small-scale industrial, commercial, institutional and recreational uses shall be directed to 
5.6.24. That major development shall not be permitted in Hamlets.

5.6.31. That notwithstanding policy 5.6.24, additional growth and development in the Hamlet of Vandorf in Whitchurch-Stouffville may be permitted in conformity with the Vandorf Preston Lake Secondary Plan, when approved, and an appropriate water and wastewater solution.

\section{Greenbelt and Oak Ridge Moraine}

Specific Areas:

6.1.11. That the Keswick Business Park Study Area is subject to Section 3.4.4 (Additional Policies for Settlement Area Expansion) of the Greenbelt Plan and special provisions in the Official Plan of the Town of Georgina. Any development of these lands will require an amendment to this Plan and the local official plan.

6.1.12. That the Vandorf-Preston Lake Community Plan is subject to Section 3.4.4 (Additional Policies for Settlement Area Expansion) of the Greenbelt Plan and policy 5.6.31 (additional growth and development in the Hamlet of Vandorf in Whitchurch-Stouffville may be permitted in conformity with the Vandorf Preston Lake Secondary Plan, when approved, and an appropriate water and wastewater solution of this Plan).

Oak Ridges Moraine:

6.2.2. That the Oak Ridges Moraine Conservation Plan, identifies land use designations and permitted uses, including the following:

- Natural Core Areas - new permitted uses are very limited and may include conservation and resource management, low intensity-recreation, or agricultural uses, as detailed in the Oak Ridges Moraine Conservation Plan.

- Countryside Areas contain rural land uses, which may include agriculture, land extensive major recreational uses, open space, major institutional, Hamlets, mineral aggregate operations, recreational and open space.

- Small-scale industrial, commercial, institutional and recreational uses shall be directed to Hamlets, Towns and Villages and the Urban Area.

- Hamlets, designated within local official plans and located within the Countryside Area are 
intended to provide opportunities for minor residential infill and small-scale industrial, commercial and institutional and recreational uses in accordance with the policies of this Plan and local official plans.

- Land extensive major recreational uses are not permitted to locate in the Agricultural area

6.2.3. That the Oak Ridges Moraine Conservation Plan designation of Settlement Areas includes portions of the Urban Area (Aurora, Newmarket, Richmond Hill, and Vaughan) and Towns and Villages (Ballantrae, King City, Mount Albert, Nobleton, and Stouffville). In these areas, policies contained in Chapter 5 (Building complete communities) of this Plan and local official plans shall guide permitted development. Where the local official plan is more restrictive than this Plan, the more restrictive policies shall apply.

6.4.2. The Rural Area designation of this Plan and local official plans establish the permitted uses within the Greenbelt Plan and acts as an overlay within the Oak Ridges Moraine Conservation Plan to inform the permitted uses within the Countryside designation of the Oak Ridges Moraine Conservation Plan.

6.4.14 That within the Oak Ridges Moraine Conservation Plan Countryside Designation in the Town of Aurora, a cluster residential development in condominium ownership is permitted subject to the following:

- Privately owned and operated communal wastewater treatment system and a privately owned and operated communal water system, approved through a Class Environmental Assessment or equivalent

- Responsibility Agreement(s) being executed for the communal wastewater treatment and water systems

- An economic/fiscal impact analysis shall be completed to confirm the financial viability of the proposal

- Prior to any development taking place, approval shall have been given to an amendment to the local official plan

- Overall density of development shall generally be compatible to that achieved through estate residential policies of the local municipal plan and shall be determined through supporting environmental and servicing studies; and,

- Design shall effectively screen development from arterial roads and existing uses through sensitive siting and landscaping 


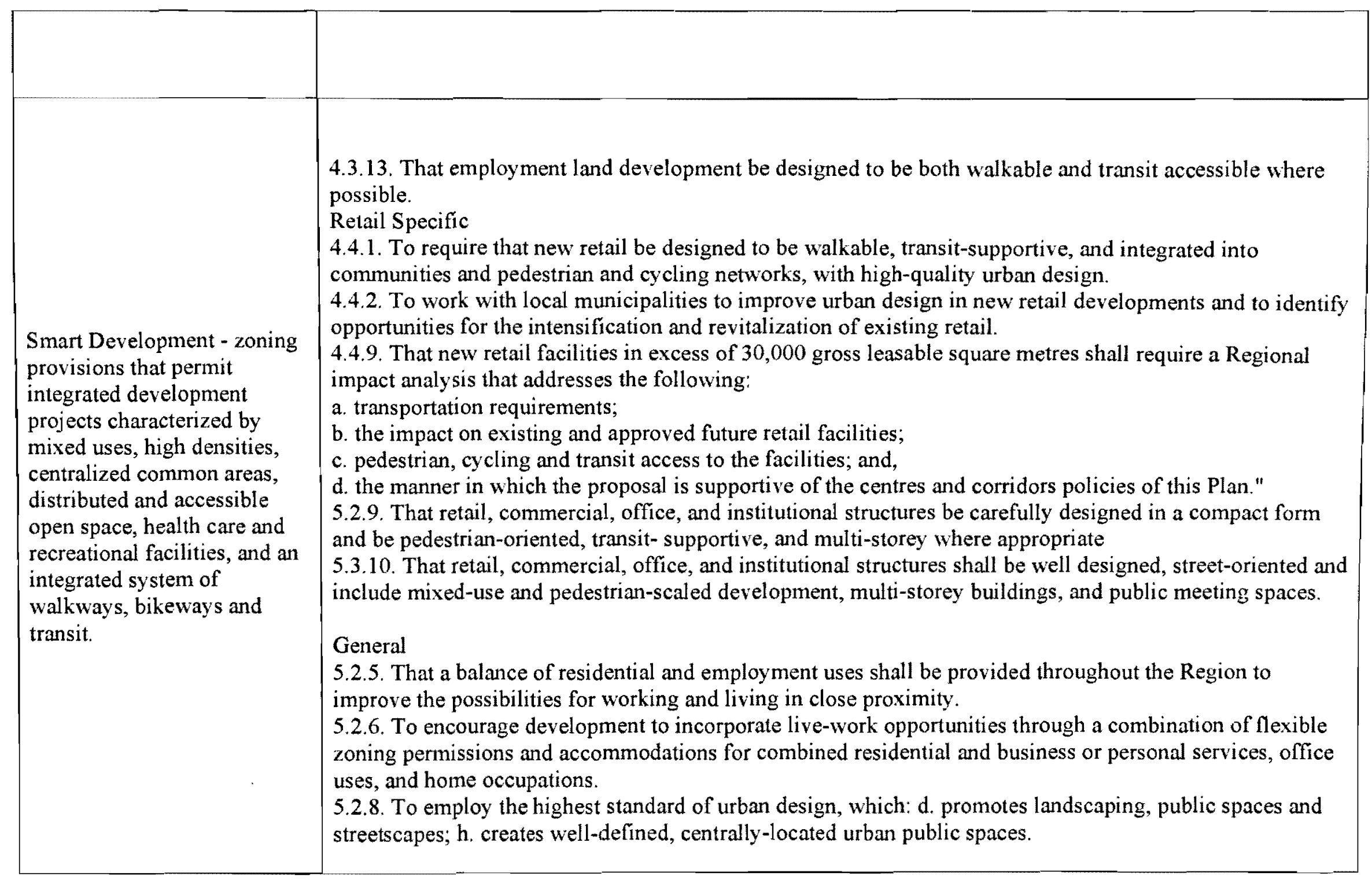


Designated Greenfield Area

5.2.16. To encourage that secondary and subdivision plans within the designated greenfield area that are not approved, be developed in accordance with policies 5.6.4 through 5.6.16.

Intensification Areas

5.3.7. That open spaces shall be provided that include:

a. active recreational facilities;

b. passive parks and open spaces;

c. meeting places and urban squares that incorporate art, culture and heritage; and,

d. opportunities for community gardening."

5.3.11. That human services facilities be located in close proximity to public transit.

Regional Centres and Corridors

3.1.5. That public health and other human services be incorporated into the design and evaluation of new community areas and Regional Centres and Corridors.

4.2.4. To require a mixed-use pedestrian environment in Regional Centres and Corridors that promotes transit use and enhances these areas as destinations for business, entertainment and recreation. Yonge Street 4.2.6. To work with local municipalities to ensure that Regional Centres and Corridors include a significant amount of mixed-use, pedestrian- oriented, and street-related retail.

5.4.2. To recognize and support a hierarchy within the system of Regional Centres and Corridors, in keeping with the York Region 2031 Intensification Strategy, wherein Regional Centres are focal points for the highest densities and mix of uses.

5.4.5. That development within Regional Centres and Corridors be of an urban form and design that is compact, mixed-use, oriented to the street, pedestrian- and cyclist-friendly, and transit supportive.

5.4.6. That comprehensive secondary plans for Regional Centres and key development areas along Regional Corridors be prepared by local municipalities and implemented in co-operation with the Region and related agencies. These secondary plans shall include:

b. the establishment, implementation and/or continuation of a fine-grained street grid that incorporates sidewalks and bicycle lanes;

c. an urban built form that is massed, designed and oriented to people, and creates active and attractive streets for all seasons with ground-floor uses such as retail, human and personal services; 
d. a concentration of the most intensive development and greatest mix of uses within a reasonable and direct walking distance of rapid transit stations and/or planned subway stations;

f. policies that sequence development in an orderly way, co-ordinated with the provision of human services, transit and other infrastructure;

j. provisions for an urban public realm, including passive and active parks and meeting places, such as urban squares, which incorporate art, culture and heritage, and that contribute to a sense of place and clear identity;

1. policies to ensure natural and recreational connections and enhancements to and within local and Regional Greenlands Systems; (in env't protect in word)

p. provisions for human services that meet local community and Region-wide needs. "

5.4.14. To require innovative approaches for the delivery of infrastructure that support city building in Regional Centres and Corridors, including:

a. working with utility providers to ensure appropriate utility design and placement, including burying cables and structures, consistent with Transit-Oriented Design guidelines for Regional Centres and Corridors; and,

b. transit and surface and sub-surface subway infrastructure, including transformer stations, vent shafts, tuming loops, transit stations and emergency exits."

5.4.15. To require local municipalities to adopt official plan policies and related zoning by-law provisions, to provide community benefits in Regional Centres and Corridors in exchange for additional height and density, consistent with the Increased Density provision of the Planning Act. Community benefits shall include consideration of:
a. transit station improvements, in addition to lands required as a condition of development approval;
b. social housing;
c. direct pedestrian connections to transit stations;
d. Regional community and health facilities;
e. Regional emergency medical services and police stations;
f. additional facilities and services identified by local municipalities; and,
g. appropriate provisions for pedestrian and cycling facilities."

5.4.20. That the planning and implementation of Regional Centres will provide: $b$. a diverse mix of uses and built form, to create vibrant and complete communities with live-work-shop opportunities; c. mobility choices and associated facilities for all residents and employees for walking, cycling, 
transit, and carpooling, which shall be supported through the preparation of a mobility plan;

d. the construction of a fine-grained street grid that facilitates the flexible and efficient movement of people and goods;

e. accessible human services and related facilities, identified by and delivered through a community and human services plan to ensure integration with development;

f. sequencing of development that is co-ordinated with infrastructure availability, including transportation, water and wastewater, and human services; and,

g. a long term resident-to-employee target ratio of 1:1."

5.4.25. To encourage the location of Regional-scale hospitals and entertainment and meeting facilities, including stadiums, arenas, and convention centres, in the Regional Centres.

5.4. 23. That the Regional Centres contain the highest development densities and greatest mix of uses in the Region, and shall achieve a minimum density of:

a. 2.5 floor space index per development block. This requirement meets and exceeds the Places to Grow: Growth Plan for the Greater Golden Horseshoe gross minimum density requirement of 200 residents and jobs combined per hectare; and,

b. 3.5 floor space index per development block, at, and adjacent to, the Vaughan Metropolitan Centre Station on the Spadina Subway Extension, and the Langstaff/Longbridge and Richmond Hill Centre Stations on the Yonge Subway Extension.

5.4.28. That Regional Corridors are planned to function as urban main streets that have a compact, mixeduse, well-designed, pedestrian-friendly and transit-oriented built form.

5.4.30. That the boundaries of the Regional Corridors be designated by the local municipality, based on: - Reasonable and direct walking distances between the Regional Corridor street frontage and adjacent lands;

- Contiguous parcels that are desirable and appropriate locations for intensification and mixed-use development; and,

- Compatibility with and transition to adjacent and/or adjoining lands.

5.4.31. That the most intensive and widest range of uses within the Regional Corridors be directed to specific intensification areas, identified by local municipalities as key development areas. These areas shall include the following segments of the Regional Corridor:

- Lands within a reasonable and direct walking distance from all planned subway stations, and select rapid transit stations as identified by local municipalities;

- Major transit station areas immediately adjacent to transit stations and terminals, including GO 
Transit; and,

- Large and/or contiguous properties that are under-utilized, and are appropriate and desirable locations for redevelopment or intensification.

\section{Summary of Findings:}

The analysis identified 29 policies related to smart development. York's Regional Centres and Corridors were found to have all the characteristics of smart development, that is, provisions for mixed uses, high densities, centralized common areas, distributed and accessible open space, health care and recreational facilities, and an integrated system of walkways, bikeways and transit. Local Centres and Corridors, and Designated Greenfields had all the provisions of smart development except provisions for high densities. New Community areas were missing provisions of high density and integrated bikeways. Retail Specific areas had all the provisions except open space, health care and recreational facilities. Intensification areas were missing provisions for mix use, high density and integrated walkways and bikeways.

The smart development provisions that occurred most frequently included public spaces, integrated walkways and transit followed by recreational facilities and open spaces. The smart development provisions, which had the lowest presence, included high density and integrated bikeways, although, the Region and the GGH Growth Plan established density targets, and York has its own Bicycle Access Plan.

\section{Outstanding policies:}

3.3.1. To implement, update and monitor the York Region Human Services Strategy, in conjunction with other growth management initiatives to ensure the integration of human services planning with land use, infrastructure and fiscal planning (also in excel smart tab)

Policies to manage development by defining ecoindustrial parks

Purchase (transfer) of development rights - policy allowing the municipality to purchase (transfer)
No policies found on establishing and/or managing eco-industrial parks.

York Region has policies allowing the municipalities to purchase development rights in order to protect and enhance the Regional Greenland Systems and its functions.

2.1.3 That the Regional Greenlands System includes regional linkages and will be the focus of enhancement 
development rights from landowner for areas that have received special conservation designation.

and land securement initiatives to achieve the Greenlands System Vision identified on Map 2 of this Plan 2.1.16 To undertake land securement, with partners, focused primarily within the Regional Greenlands System. Land securement can include conservation easements, donations, or land purchases, and education and stewardship promotion.

2.1.17 That where lands within the Regional Greenlands System are held in private ownership, nothing in this Plan requires that these lands be free and available for public use. Similarly, York Region Council is not obligated to purchase lands identified as part of the Regional Greenlands System.

2.1.18 To update the Regional Greening Strategy, including the land securement criteria, to ensure implementation complementary to the policies of this Plan.

2.1.19. That land securement initiatives assist in implementing the Regional Greenlands System trails network.

Summary of Findings: York Region has policies to purchase development rights in order to protect the Regional Greenland System and implement trails network within the system, however, the municipality is not obligated to purchase lands identified as part of the Regional Greenland System.

Policies establishing minimum density targets requirements for industrial, commercial and residential zones

\begin{tabular}{|l|l|l|}
\hline Policy & Area & Density / Intensification Targets \\
\hline 4.3 .14 & $\begin{array}{l}\text { Employment } \\
\text { lands }\end{array}$ & Ave. min. 40 jobs / ha in developable area \\
\hline 4.3 .14 & $\begin{array}{l}\text { Employment } \\
\text { lands }\end{array}$ & Higher than above for lands within or adjacent to centres and corridors \\
\hline 5.2 .14 & $\begin{array}{l}\text { Designated } \\
\text { Greenfield } \\
\text { area }\end{array}$ & Ave. min. 50 residents and jobs per ha combined in developable area \\
\hline 5.3 .1 & $\begin{array}{l}\text { Residential } \\
\text { development }\end{array}$ & $\begin{array}{l}\text { By 2015 and each year after, min. 40\% of all development will occur within } \\
\text { built-up area }\end{array}$ \\
\hline 5.4 .23 & $\begin{array}{l}\text { Regional } \\
\text { Centres }\end{array}$ & $\begin{array}{l}\text { Min. 2.5 floor space index per development block or min. 200 residents and } \\
\text { jobs combined per ha. }\end{array}$ \\
\hline 5.4 .23 & $\begin{array}{l}\text { Regional } \\
\text { Centres }\end{array}$ & $\begin{array}{l}\text { Min. 3.5 floor space index per development block - at, and adjacent to, the } \\
\text { Vaughan Metropolitan Centre Station on the Spadina Subway Extension, and } \\
\text { the Langstaff/Longbridge and Richmond Hill Centre Stations on the Yonge } \\
\text { Subway Extension. }\end{array}$ \\
\hline
\end{tabular}




\begin{tabular}{|c|c|c|}
\hline \multirow[t]{3}{*}{$5,4.33$} & \multirow{3}{*}{$\begin{array}{l}\text { Regional } \\
\text { Corridors - } \\
\text { Secondary } \\
\text { plans }\end{array}$} & $\begin{array}{l}\text { Min. } 3.5 \text { floor space ind ex per development block at, and adjacent to, the } \\
\text { Steeles West Station on the Spadina Subway Extension, and the Steeles } \\
\text { Station on the Yonge Subway Extension; }\end{array}$ \\
\hline & & $\begin{array}{l}\text { Min. } 2.5 \text { floor space index per development block, at, and adjacent to, the } 407 \\
\text { Transitway Station on the Spadina Subway Extension, and the Clark and } \\
\text { Royal Orchard Stations on the Yonge Subway Extension }\end{array}$ \\
\hline & & $\begin{array}{l}\text { An appropriate floor space index per development block for lands at or } \\
\text { adjacent to other rapid transit stations and/or other select areas, as determined } \\
\text { by the local municipality, in consideration of community context and } \\
\text { character. }\end{array}$ \\
\hline $5.4 . \overline{34}$ & $\begin{array}{l}\text { Regional } \\
\text { Corridors }\end{array}$ & 2.5 floor space index for developable areas. \\
\hline \multirow[t]{2}{*}{5.6 .3} & \multirow{2}{*}{$\begin{array}{l}\text { New } \\
\text { community } \\
\text { areas }\end{array}$} & Min density of 20 residential units per hectare in developable area. \\
\hline & & Min. density of 70 residents and jobs per hectare in developable area. \\
\hline
\end{tabular}

York Region, as part of the Growth Plan for GGH requirements, has created York Region 2031

Intensification Strategy to achieve intensification and the intensification targets (5.3.2) and requires local municipalities to base their own intensification strategies based on the Region's strategy (5.3.3). And that planning and implementation of local centres and corridors shall be consistent with the intensification policies of Section 5.3 (Intensification) of the ROP (5.5.5). In addition, the Region will work with local municipalities to identify opportunities for the intensification of existing retail (4.4.2). Lastly, the Region prohibits the approval of local municipal plan and zoning by-law amendments that would have the effects of reducing the density of a site in areas that have been approved for medium- or high-density development, unless the need is determined through a municipal comprehensive review (3.5.23).

To encourage employment intensification and higher density employment uses in Regional Centres and Corridors, in support of the policies in Section 5.4 (Building Complete Communities) of this Plan (4.3.19). The Region also requires flexible and adaptable employment lands which allow for redevelopment and intensification (4.3.16) and to review and monitor opportunities for employment land intensification (4.3.17). 
Comprehensive secondary plans to include and meet the minimum density requirements and targets established by the Region and the Province are required for Regional Centres and key development areas along the Regional Corridors (5.4.6), and within the designated greenfield areas, that are not completely built, the plans are should be re-examined to determine whether the minimum targets in the developable area can be achieved $(5.2 .15)$.

Together, the Province and local municipalities, will establish common density and intensification measurements, definitions and monitoring tools (5.2.18).

\section{Additional policies:}

4.3.18. To require local municipalities to conduct 5-year reviews of employment lands to accommodate employment intensification.

$5.6,20$. That new development areas within Towns and Villages, be subject to comprehensive secondary plans based on the following:

- water and wastewater services are available;

- the plan considers the entire Town or Village and integrates the development into the existing community;

- best efforts to achieve a minimum density requirement of 50 residents and jobs combined per hectare in the developable area;

- best efforts are made to incorporate policies 5.6.4 through 5.6.16 (new community areas prioritize people, sustainability,

- and livability) of this Plan; and,

- best efforts to encourage development within the built-up area of the Towns and Villages that is consistent with the appropriate policies in Section 5.3 (intensification) of this Plan.

5.6.26. That residential infilling shall be encouraged to occur in depth rather than along strips and should complement the historic character of the settlement. Any increase in the number of residents through infilling must not change the rural nature of the Hamlet.

\section{Environmental Sustainability}

Identify and Protect

Environment - Policy

establishing a systematic

\section{Policy establishing a systematic identification of environmentally sensitive and biologically significant} open spaces in the region and corridors to connect them 
identification and strategic protection of environmentally sensitive and biologically significant open spaces in the region and corridors to connect them by prohibiting development in these spaces

\subsection{Identification - the WHAT.}

The Region has identified the following areas as environmentally sensitive and biologically significant open spaces and corridors:

A. Regional Greenland System - consists of cores, corridors, and linkages. These include the Oak Ridges Moraine Conservation Plan Natural Core Area and Natural Linkage Area designations, the Natural Heritage System within the Protected Countryside of the Greenbelt Plan, key natural heritage features, key hydrologic features and functions, and the lands necessary to maintain these features within a system (2.1.2) A1.0 Components of the Regional Greenland System (2.2.1) consists of key natural heritage features and key hydrologic features and include:

a. significant habitat of endangered species, threatened species and special concern species (the species at risk in Ontario List);

b. fish habitat;

c. wetlands;

d. Life Science Areas of Natural and Scientific Interest;

e. Environmentally Significant Areas;

f. significant valley lands;

g. significant woodlands;

h. significant wildlife habitat;

i. sand barrens, savannahs and tallgrass prairies;

j. lakes and their littoral zones;

k. permanent and intermittent streams;

1. kettle lakes;

$\mathrm{m}$. seepage areas and springs; and,

n. Lake Simcoe Shoreline.

A2.0 Key natural heritage and hydrologic features shall be identified in accordance with criteria provided by Province on a site by site basis or through appropriate studies (2.2.3)

A2.1. That Environmentally Significant Areas on the Oak Ridges Moraine or within the Natural Heritage System of the Protected Countryside of the Greenbelt Plan, which have been identified by a conservation authority, are also considered to be key natural heritage features, subject to the same requirements for protection and study as those identified in the Oak Ridges Moraine Conservation Plan and Greenbelt Plan for Life Science Areas of Natural and Scientific Interest (2.2.24).

A3.0 That the Oak Ridges Moraine Conservation Plan, identifies land use designations and permitted uses, 
including the following:

a. Natural Core Areas have a high concentration of key natural heritage features, key hydrologic features, and/or landform conservation areas and are critical to maintaining the integrity of the Moraine as a whole. New permitted uses are very limited and may include conservation and resource management, low

intensity-recreation, or agricultural uses, as detailed in the Oak Ridges Moraine Conservation Plan. b. Natural Linkage Areas form part of a central corridor system that supports or has the potential to support movement of plants and animals between the Natural Core Areas, Natural Linkage Areas, river valleys and stream corridors. Limited new uses may include those permitted in the Natural Core Area designation, as well as mineral aggregate operations and wayside pits, as detailed in the Oak Ridges Moraine Conservation Plan.

B. Local Greenland System - Local municipalities to develop local Greenland systems that identify enhancement areas and linkage opportunities in existing (2.1.4) and new communities (2.1.11).

B1.0 Local municipalities to identify key features in local official plans and zoning by laws $(2,2.8)$.

B2.0 That in the Urban Area and Towns and Villages, the Regional Greenlands System shall be identified more specifically in local official plans and secondary plans and integrated into community design (2.1.9).

C. Wetlands as identified by the Province, provincially significant wetlands. The Province has enacted a policy statement under the Planning Act that prohibits development in provincially significant wetlands. Other wetlands that have not been identified as provincially significant, but which have been formally evaluated by the Ministry of Natural Resources, also exist within the Region. Map 4 shows the general location of all evaluated wetlands, as well as identified wetlands within the Oak Ridges Moraine, Greenbelt, and Lake Simcoe watershed. More detailed information, as well as more recent wetland evaluations is available from the Province. (Section 2.2).

D. Woodlands - significant woodlands study performed

E. Oak Ridges Moraine, Greenbelt and Lake Simcoe.

F. The landform conservation areas within the Oak Ridges Moraine are shown on Figure 1 (2.2.51).

G. Water Systems

H. 6.1.5 That lands designated as Agricultural Area, Rural Area or Urban Area in this Plan that are also part of the Natural Heritage System in the Greenbelt Plan are subject to the Regional Greenlands System 
policies of Section 2.1 of this Plan, and are intended to function as part of the Regional Greenlands System in the long term.

\subsection{Identification through Studies}

- To examine the feasibility of undertaking studies complementary to the Regional Greenlands System, such as wildlife and terrestrial linkage plans (2.1.26).

- To work with conservation authorities, local municipalities and the Province in establishing, maintaining and improving a database on the Regional Greenlands System (2.1.27).

- To work with municipal partners and stakeholders in implementing and monitoring the Rouge North Management Plan (2.1.28).

- To cooperate with conservation authorities, province, local municipalities to further defined and better understand key features and their functions. (2.2.12)

- Specific studies can be used to determine/verify the significance of woodlands (2.2.41).

Summany of Findines (Iflentify die 1 hat and Sudies):

The Region identified the following areas requiring protection: Regional and Local Greenland Systems, and within them key natural heritage and hydrologic features, natural core and linkage areas, significant

woodlands, natural heritage system, protected country side, wetlands, landform area, water systems - within and outside Oak Ridges Moraine, the Greenbelt area and Lake Simcoe (A-G). In addition, lands designated as Agricultural Area, Rural Area or Urban Area in this Plan that are also part of the Natural Heritage System in the Greenbelt Plan are subject to the Regional Greenlands System policies of Section 2.1 (Regional

Greenland system) of this Plan, and are intended to function as part of the Regional Greenlands System in the long term (6.1.5). The Region has also identified a number of studies which will aid in the identification and protection of environmentally significant areas, they consist of having a database of the Regional

Greenlands System (2.1.27), to define and understand key features and their functions (2.2.12), studies to conform significant woodlands (2.2.41) and to examine the feasibility to undertake more studies such as wildlife and terrestrial linkage plans in the Regional Greenland System (2.1.26).

Lastly, the Region has specified that they will implement the following plans: Rouge North Management Plan (2.1.28).

3.0 Adjustments to the Identified Areas:

Specific studies can be used to determine/verify the significance of woodlands (2.2.41) but amendment to 
Plan not required if woodlands does not meet criteria in 2.2 .39 which is as follows:

a. contains globally or provincially rare plants, animals or communities as designated by the Natural Heritage Information Centre;

b. contains species designated by the Committee on the Status of Endangered Wildlife in Canada or by the Committee on the Status of Species at Risk in Ontario as threatened, endangered, or of special concern;

c. is within 30 meters of a key hydrologic feature;

$\mathrm{d}$. is over 2 hectares and (i) is within 100 meters of another key natural heritage feature or key

hydrologic feature or (ii) occurs within the Regional Greenlands System.

e. is south of the Oak Ridges Moraine and is 4 hectares or larger in size;

$f$. is north of the Oak Ridges Moraine and is 10 hectares or larger in size; or,

g. on the Oak Ridges Moraine the woodland will be evaluated for significance based on the

requirements of the Oak Ridges Moraine Conservation Plan and associated technical papers.

That once the local Greenland system, approved at a local level, revisions to local Greenlands systems will be included within this Plan without amendment (2.1.5).

Minor refinements to the extent or presence of key features resulting from studies conducted in accordance with the Greenbelt, Oak Ridges Moraine Conservation and Lake Simcoe Protection Plans and information from the province or conservation authority do not require an amendment to the Plan (2.2.23).

Region will amend the plan to update provincially significant wetlands (2.2.37)

To amend mapping and policies in this Plan when significant recharge areas or vulnerable aquifer areas are identified (2.3.6).

\section{Summary of Findings (Adjustments to Environmentally Significant Areas):}

The Region will not amend the ROP if studies or local official plans refine the areas, for example, if a study identifies woodlands but they are not significant (2.2.41 and 2.2.39), when local Greenland system boundaries change during alignment of local official plans to ROP (2.1.5), when minor refinements to the extent or presence of key features (2.2.23). The Region will amend the ROP to update provincially significant wetlands (2.2.37) and when significant recharge areas or vulnerable aquifer areas are identified (2.3.6)

Policy establishing a strategic protection of environmentally sensitive and biologically significant open 


\section{General and Governance}

6.1.8 That where there is a conflict between policies of this Plan, local official plans and the Greenbelt Plan, the more restrictive policy shall apply, except in the case of agriculture, mineral aggregate and wayside pits, where this Plan and local official plans cannot be more restrictive than the Greenbelt Plan.

6.2.15 those applications for major development are required to meet the provisions of the Oak Ridges Moraine Conservation Plan.

2.2.26 That in the Urban Area and Towns and Villages, as designated on April 22, 2002, where secondary plans, official plans, zoning by-laws, or Master Environmental Servicing or Functional Servicing Plans are approved based on environmental studies that have identified minimum vegetation protective zones that are different from those identified in the Oak Ridges Moraine Conservation Plan, then the standards established within those plans shall prevail.

2.2.27 That in the Urban Area, Towns and Villages, and Hamlets designated on February 28, 2005, where secondary plans, official plans, zoning by-laws, or Master Environmental Servicing or Functional Servicing Plans are approved based on environmental studies that have identified minimum vegetation protective zones that are different from those identified in the Greenbelt Plan, then the standards established within those plans shall prevail.

2.2.11 Prohibit lands identified as environmentally significant, life science of natural and scientific interest from used for purposes of pit/quarry, wayside pit or quarry, batching/asphalt plants or new waste disposal site

2.2.13 To encourage private/public landowners with key features to manage lands in a manner that conserves and enhances the features in accordance with this plan

2.2.29 That the technical papers associated with the Oak Ridges Moraine Conservation Plan and the Greenbelt Plan be consulted to provide clarification in implementing the policies related to key natural heritage features and key hydrologic features within the Provincial Plans. In the event of a conflict in the interpretation of the provincial technical papers and the policies of this Plan, the policy that is more protective of the feature will apply.

6.2.9. That existing institutional uses and expansions are permitted subject to the Existing Use provisions of the Oak Ridges Moraine Conservation Plan and local official plans and zoning by-laws. When expansion of such uses is applied for, the applicant shall demonstrate that the expansion will not adversely affect the ecological integrity of the Oak Ridges Moraine Conservation Plan Area. Additional studies as identified in 
Parts III and IV of the Oak Ridges Moraine.

Conservation Plan may be required.

6.3.13 And within the Holland Marsh Specialty Crop Area, the Region will encourage and support the Province in balancing continued agricultural production and potential expansion with natural heritage values and policies (6.3.13)

\section{Regional Greenland System}

2.1.1 To protect and enhance the Regional Greenlands System and its functions shown on Map 2 and to direct new development and site alteration away from the System.

2.1.7 That the Regional Greenlands System shall be enhanced through Regional greening initiatives, partnerships, infrastructure projects and urban development to achieve ecological gains for the System 2.1.8 Development applications within $120 \mathrm{~m}$ of the system shall be accompanied by an environmental impact statement. This statement shall detail the impact of the development on the Regional Greenlands System and shall provide details of enhancement opportunities and any mitigative measures.

2.1.14 Infrastructure design and construction be sensitive to the features and functions of the system including innovative technologies to minimize impact on the system (2.1.14).

2.1.15 Planning, design and construction of infrastructure projects shall enhance and invest in the system 2.1.22 To ensure that within the portions of the Regional Greenlands System that are identified as the

Natural Heritage System of the Protected Countryside within the Greenbelt:

a. the full range of existing and new agricultural, agricultural-D1 related and secondary agricultural uses and normal farm practices is permitted

b. new buildings or structures for agriculture, agricultural-related and secondary agricultural uses are not subject to policies 2.1.22.c(i) through 2.1.22.c(iii), but are subject to Section 2.2 of this Plan;

c. new development or site alteration permitted by the Greenbelt Plan shall:

(i) cause no negative effects on key natural heritage features or key hydrologic features or their functions;

(ii) enhance connectivity between key natural heritage features and key hydrologic features for the movement of native plants and animals across the landscape; and,

(iii) ensure that the disturbed area of any site does not exceed $25 \%$, and the impervious surface does not exceed $10 \%$, of the total developable area, except where otherwise permitted within the Greenbelt Plan. 
d. where permitted non-agricultural uses are proposed within the Natural Heritage System of the Protected Countryside, applicants shall demonstrate that:

(i) at least $30 \%$ of the total developable area of the site will remain or be returned to natural selfsustaining vegetation;

(ii) connectivity between key natural heritage features or key hydrologic features located within 240 meters of each other is maintained or enhanced; and.

(iii) buildings or structures do not occupy more than $25 \%$ of the area outside of key natural heritage features and key hydrologic features and their minimum vegetated protection zones.

2.1.23 Prohibit pits or quarries, batching/asphalt plants and new waste disposal sites in the system. Permit wayside pits or quarries or mineral aggregate operations within the system in portions designated as Natural Linkage Area and Country side Area and meet Oak Ridges Moraine Conservation Plan and portions of the protected countryside as long as they meet Greenbelt Plan requirements.

5.3.8 That the Regional Greenlands System shall be protected and enhanced and include pedestrianaccessible green spaces and passive parks, where appropriate.

5.4.6. That comprehensive secondary plans for Regional Centres and key development areas along Regional Corridors be prepared by local municipalities and implemented in co-operation with the Region and related agencies. These secondary plans shall include: 1 . policies to ensure natural and recreational connections and enhancements to and within local and Regional Greenlands Systems;

5.6.14 That a Regional Greenlands System Plan shall be prepared that:

a. evaluates the potential impact of development and ensures the protection, enhancement, and securement of all key natural heritage features and key hydrologic features of the System;

b. identifies strategic areas for enhancement and restoration to maximize the quality of the entire System;

c. identifies how infrastructure projects within the System, including permitted stream crossings for streets, water and wastewater systems, contribute to an overall ecological gain by increasing natural cover, enhancing ecological function, providing recreational access or contributing to off-site enhancements;

d. identifies securement opportunities and management requirements;

e. includes a trail system, which is integrated into the mobility systems of the community;

f. examines the feasibility of providing local community gardening plots where appropriate, outside of the lands dedicated for parkland; and, g. identifies hazard lands and hazardous sites, incorporates them into the Greenlands System, directs 
development away from these areas and includes an appropriate buffer or access allowance. 6.1.6 That new multiple units or multiple lots, as defined in the Greenbelt Plan, for residential dwellings, such as estate residential developments, adult lifestyle, and retirement communities are prohibited, except in the Serviced Lakeshore Residential Area in the Town of Georgina.

7.2.10 That the construction of proposed pedestrian and cycling routes will protect and enhance the Regional Greenlands System.

7.2.45 That street widenings and proposed Regional streets shall protect and enhance the Regional Greenlands System.

\section{Summary of Findings (Regional Greenland System):}

The Region's direction is to protect and enhance the Regional Greenlands System and its functions and to direct new development and site alteration away from the System (2.1.1) and to enhance the System through Regional greening initiatives, partnerships, infrastructure projects and urban development to achieve ecological gains for the System (2.1.7). The Region plans to prepare a Regional Greenlands System Plan that will evaluate the potential impact of development and ensure the protection, ecological gain, enhancement, restoration, and securement of the System and its components (5.6.14). The Region intends to include pedestrian-accessible green spaces and passive parks, where appropriate (5.3.8) and that the construction of proposed pedestrian and cycling routes will protect and enhance the Regional Greenlands System (7.2.45).

The following development or projects are prohibited in the Greenland system: pits or quarries, batching/asphait plants and new waste disposal sites (2.1.23).

The development and infrastructure projects that are permitted within the Regional Greenland System are allowed in specific areas or require additional studies and/or requirements be met to protect the system:

- Development applications within $120 \mathrm{~m}$ of the system shall be accompanied by an environmental impact statement. This statement shall details of enhancement opportunities and any mitigative measures 2.1.8).

- Infrastructure design and construction be sensitive to the features and functions of the system including innovative technologies to minimize impact on the system (2.1.14) and shall enhance and invest in the system (2.1.15)

- The full range of existing and new agricultural, agricultural related and secondary agricultural uses and 
normal farm practices is permitted, as well as new buildings or structures for agriculture, agriculturalrelated and secondary agricultural uses in the Natural Heritage System of the Protected Countryside within the Greenbelt in the Regional Greenland System but are subject to Section 2.2 of this Plan with an objective to protect and enhance all the components of the Regional Greenland System (2.1.22 a and b) and demonstrate that at lenst $30 \%$ of the total developable area of the site will remain or be returned to natural self-sustaining vegetation, connectivity between key natural heritage features or key hydrologic features located within 240 meters of each other is maintained or enhanced, buildings or structures do not occupy more than $25 \%$ of the area outside of key natural heritage features and key hydrologic features and their minimum vegetated protection zones $(2.1 .22 \mathrm{~d})$.

- Any development or site alteration in the Natural Heritage System of the Protected Countryside within the Greenbelt in the Regional Greenland System shall be permitted by the Greenbelt Plan and in addition cause no negative effects, enhance connectivity for the movement of native plants and animals across the landscape; and ensure that the disturbed area of any site does not exceed $25 \%$, and the impervious surface does not exceed $10 \%$, of the total developable area, except where otherwise permitted within the Greenbelt Plan $(2.1 .22 \mathrm{c})$.

- Permit wayside pits or quarries or mineral aggregate operations within the system in portions designated as Natural Linkage Area and Countryside Area and meet Oak Ridges Moraine Conservation Plan and portions of the protected countryside as long as they meet Greenbelt Plan requirements (2.1.23).

- That new multiple units or multiple lots, as defined in the Greenbelt Plan, for residential dwellings, such as estate residential developments, adult lifestyle, and retirement communities are prohibited, except in the Serviced Lakeshore Residential Area in the Town of Georgina (6.1.6).

- That street widenings and proposed Regional streets shall protect and enhance the Regional Greenlands System (7.2.45).

\section{Key Natural Heritage features and Key Hydrologic features}

- Prohibit development/site alteration within key features and adjacent lands unless it is demonstrated that no negative impact will result (2.2.4). 2.2.4 does not apply to fish habitat unless provincial/federal requirements (2.2.7)

- Prohibit the removal of key features by unauthorized site development/alteration (2.2.6).

- Passive recreational uses are permitted within key features as long as it is demonstrated that no negative impact will result (2.2.4) and meet the requirements of Oak Ridges Moraine, Greenbelt and Lake Simcoe Protection Plans. (2.2.5) 
- Where key features cross the boundaries of the Oak Ridges Moraine, Lake Simcoe watershed, Greenbelt , the most protective policies apply (2.2.9)

- Development/site alteration not permitted in key features on the Oak Ridges Moraine, Greenbelt and Lake Simcoe watershed except as provided by the Oak Ridges Moraine, Greenbelt and Lake Simcoe protection Plans (2.2.14)

- That a minimum of 30 meters is required for vegetation protection zone for key features on the Oak Ridges Moraine or in Lake Simcoe watershed outside of existing settlement areas - or protection zone as required by the Oak Ridges Moraine Conservation Plan (2.2.15)

- 2,2.20 That an application for development or site alteration in the Lake Simcoe watershed that is within 120 meters of a key natural heritage feature, a key hydrologic feature or the Lake Simcoe Shoreline outside of existing settlement areas as defined by the Lake Simcoe Protection Plan, shall provide for the establishment or re-establishment and maintenance of natural self sustaining vegetation.

- 2.2.25 That within the Oak Ridges Moraine Conservation Plan, and the Greenbelt Plan Areas, no new agricultural uses, agriculture-related uses, or accessory uses shall be permitted within key natural heritage features and key hydrologic features and their associated minimum vegetation protection zone if the lands were not being used for that use on November 15, 2001, and February 28, 2005 respectively

- 6.2.10. that all applications, matters or proceedings as defined under the Oak Ridges Moraine Conservation Act, 2001, commenced on or after November 17, 2001 are required to conform to the Oak Ridges Moraine Conservation Plan.

- 6.2.11. That applications in Natural Core, Natural Linkage and/or Countryside Areas that were commenced but were not decided prior to November 17,2001, as defined in the Oak Ridges Moraine Conservation Act, 2001, are required to conform with the prescribed provisions of the Oak Ridges Moraine Conservation Plan.

- 6.2.12. That applications in the Natural Core and/or Natural Linkage Areas that were commenced and decided before November 17, 2001 as defined in the Oak Ridges Moraine Conservation Act, 2001 are not subject to the provisions of the Oak Ridges Moraine Conservation Plan provided that the use, building or structure for which the application was intended is legally existing as of March 27, 2003.

- 6.2.13. That notwithstanding policies $6.2 .9,6.2 .10$ and 6.2 .11 , where a planning application is submitted after November 17,2001 as a direct result of a condition attached to a provisional consent, a draft plan of subdivision or a draft plan of condominium, the application shall be completed under the same system in effect as the original approval in accordance with the Further Approvals provisions of the Oak Ridges Moraine Conservation Act, 2001. In addition, any development permission established by such a 


\section{Summary of Findings (Kev Features):}

The Region is permitting development within key features and adjacent lands in specific areas in the system or require additional studies and/or requirements be met to protect the system. These policies are similar to the Regional Greenland system.

The Region prohibits the removal of key features by unauthorized site development and alteration (2.2.6). The Region does not allow new agricultural uses, agriculture-related uses, or accessory uses within key natural heritage features and key hydrologic features and their associated minimum vegetation protection zone within the Oak Ridges Moraine Conservation Plan, and the Greenbelt Plan Areas if the lands were not being used for that use on November 15, 2001, and February 28, 2005 respectively (2.2.25). The Region does not permit development and site alteration in the key features within the Oak Ridges Moraine,

Greenbelt and Lake Simcoe watershed except as provided by the Oak Ridges Moraine, Greenbelt and Lake Simcoe protection Plans (2.2.14).

The Region prohibits development and site alteration within key features and adjacent lands unless it is demonstrated that no negative impact will result (2.2.4). And for the fish habitat the Region needs to follow the exceptions under the provincial/federal requirements $(2.2 .7)$.

The Region does permits passive recreational uses within key features as long as it is demonstrated that no negative impact will result (2.2.4) and meet the requirements of Oak Ridges Moraine, Greenbelt and Lake Simcoe Protection Plans. (2.2.5). And that a minimum of 30 meters is required for vegetation protection zone for key features on the Oak Ridges Moraine or in Lake Simcoe watershed outside of existing settlement areas - or protection zone as required by the Oak Ridges Moraine Conservation Plan (2.2.15)

Any applications, matters or proceedings commenced after November 17,2001 or were initiated before that date but there was no decision reached need to conform to the Oak Ridges Moraine Conservation Plan (6.2.10 and 6.2.11).

Outstanding policies: 6.2 .12 and 6.2 .13 


\section{Lake Simcoe Watershed Features}

- That a minimum of 100 meters of vegetation protection zone is required for Lake Simcoe shoreline outside of existing settlement - as defined in Lake Simcoe Protection Plan (2.2.16)

- Significant alteration of Lake Simcoe shoreline or shore of freshwater estuary of a stream connected to Lake Simcoe is not permitted except provided in the Lake Simcoe Protection Plan (2.2.17)

- 2.2.21 that outside settlement areas as defined by the Lake Simcoe Protection Plan, a proposal for development or site alteration within 240 meters of the Lake Simcoe Shoreline must demonstrate that it will maintain, enhance or restore functional wildlife movement corridors between key natural heritage features or key hydrologic features.

- 2.22 That within the Lake Simcoe watershed, an application for development or site alteration within settlement and rural settlement areas, as defined by the Lake Simcoe Protection Plan, where applicable," shall:

a. increase or improve fish habitat in streams, lakes and wetlands, and any adjacent riparian areas;

b. include landscaping and habitat restoration that increases the ability of native plants and animals

to use valleylands or riparian areas as wildlife habitat and movement corridors;

c. seek to avoid, minimize and/or mitigate impacts associated with the quality and quantity of urban run-off into receiving streams, lakes and wetlands; and,

$\mathrm{d}$. establish or increase the extent and width of a self sustaining vegetation protection zone adjacent

to Lake Simcoe to a minimum of 30 meters where feasible.

- To implement the Lake Simcoe Protection Plan with province, conservation authorities and other agencies (2.3.15)

- To work with the Province, local municipalities, conservation authorities and other agencies to develop and support monitoring programs, identify emerging issues, support the adaptive management approach of the Lake Simcoe Protection Plan and to develop a phosphorus reduction strategy for the Lake Simcoe watershed $(2.3 .16)$.

- To amend this Plan as necessary to ensure consistency with the recommendations of Lake Simcoe subwatershed evaluations and shoreline management strategy (2.3.17).

\section{Oak Ridges Moraine}

- applications for development/site alteration on Oak Ridges Moraine shall plan/design/construction in such a way as to ensure that no buildings or alterations impede the movement of plants and animals 
between key features $(2.2 .28)$

- 2.1.21 Development/site alteration applications within Oak Ridges Moraine will only be considered if they comply with the Oak Ridges Moraine Plan.

- 6.2.14. That estate residential developments, adult lifestyle and retirement communities created by plans of subdivision or condominium are prohibited in the Natural Core, Natural Linkage and Countryside designations of the Oak Ridges Moraine unless all required applications meet the transitional provisions of the Oak Ridges Moraine Conservation Act, 2001.

- 6.2.16. that transportation infrastructure and utilities are permitted in all Oak Ridges Moraine land use designations, and key natural heritage features and key hydrologic features, where the Infrastructure provisions of the Oak Ridges Moraine Conservation Plan have been met. Demonstrated need for a project and conformity with the Oak Ridges Moraine Conservation Plan will be assessed and included as part of an Environmental Assessment Act process. If an Environmental Assessment Act process does not apply, the requirements of the Oak Ridges Moraine Conservation Plan will be met through Planning Act, Condominium Act, Local Improvement Act, or other applicable approval processes. The opening of a street within an unopened street allowance is prohibited unless all other requirements of the Oak Ridges Moraine Conservation Plan are met.

- 7.2.46. That within the Oak Ridges Moraine, all improvements to the Regional Transit and Street Networks shall conform with the policies of the Oak Ridges Moraine Conservation Plan.

- 7.3.17, that the construction or expansion of partial services is prohibited in the Oak Ridges Moraine unless it has been deemed necessary to address a serious health or environmental concern identified by the Medical Officer of Health or other designated authority.

- 6.3.9. that notwithstanding policy 6.3.8.e of this Plan, a consent for an agriculture-related use is not permitted on the Oak Ridges Moraine.

\section{Greenbelt}

6.1.4. That refinements to either the Agricultural Area or Rural Area designations found in the Greenbelt and shown on Map 8 , are not permitted unless undertaken through a municipal comprehensive review or the provincial review of the Greenbelt Plan in 2015 $6.4 .8 \mathrm{~g}$ and $\mathrm{h}$ (see Rural)

Holland Marsh Specialty Crop Area

6.3.16 That within the Holland Marsh Specialty Crop Area, the Region will encourage and support the 
Province in balancing continued agricultural production and potential expansion with natural heritage values and policies.

\section{Natural Heritage System}

- That a minimum of 30 meters of vegetation protection zone is required for Natural Heritage system/protected country side for wetlands, seepage areas and springs, fish

- habitat, permanent and intermittent streams, lakes, and significant woodlands. (2.2.18)

- Applications for development/site alterations shall be supported by natural heritage and/or hydrological evaluation as detailed in the 3 Plans if it occurs within 120 meters (2.2.19)

Endangered, Threatened and Special Concern Species and their Habitats

- Development/site alteration not permitted within this habitat (as identified in the Species at Risk in Ontario List) unless demonstrate no harm as 2.2.4 (2.2.30), within or outside of the Oak Ridges Moraine and the system (natural/protected countryside) of Greenbelt (2.2.31)

- Encourage private landowners to protect/enhance this habitat (2.2.32)

- To work with province on recovery strategies for these species $(2.2 .33)$

\section{Wetlands}

- NOTE: The province has enacted a policy statement under the Planning Act that prohibits development in provincially significant wetlands

- Prohibit development/site alteration within wetlands on Map 4 (all evaluated wetlands) unless demonstrate that no negative results as 2.2 .4 and minimum vegetation protection zone of $30 \mathrm{~m}(2.2 .34)$

- Permit development/site alteration within $120 \mathrm{~m}$ of wetlands but not within the $30 \mathrm{~m}$ vegetation zone and only if no loss to function/future impact/ in conflict (2.2.35)

- To encourage local municipalities, public agencies and private landowners to protect wetlands not identified in the Plan, to create new wetlands and enhance existing ones $(2.2 .36)$

\section{Woodlands:}

- Increase woodland cover from $22.5 \%$ to $25 \%$ (2.2.38)

- Outside of the 3 Plans areas a min. vegetation protection zone of $10 \mathrm{~m}$ from significant woodland (2.2.42)

- Prohibit development/site alteration within significant woodland and vegetation protection zone unless 
demonstrated that no negative impact as 2.2 .4 (2.2.43)

- Permit development'site alteration within significant woodland to integrate Greenland Systems, intensification/compact community design and development within woodlands objectives if ALL apply: if located in Urban Area, if located in intensification/compact design area, woodland not globally significant or does not have endangered species, if located outside Greenland system and 2.44.f $(2.2 .44)$ and compensation plan completed to Region's satisfaction (2.2.45)

- Region forest shall be sustainably managed (2.2.47)

- To encourage good forestry practices to landowners (2.2.48)

- To encourage/work with province and other stakeholders to maintain and enhance publicly/privately owned forest land (2.2.48)

\section{Landform Conservation}

- Overall - conform plans/practices/policies to Oak Ridges Moraine Conservation Plan

- 2.2.51. That landform conservation areas within the Oak Ridges Moraine are shown on Figure 1. Figure 1 is to be consulted whenever development or site alteration is proposed to determine whether the landform conservation policies of this Plan and the Oak Ridges Moraine Conservation Plan apply.

- 2.2.49. To encourage the protection of significant landscapes in a manner compatible with surrounding lands, and minimize the disruption and destruction of landscape features caused by extensive land alteration activities including mass grading, locating and constructing streets, pipelines and transmission lines.

- 2.2.50. To prohibit site alteration prior to the approval of development applications, and to require local municipalities to adopt site alteration by-laws in conformity with the Municipal Act and the Lake Simcoe Protection Plan to prevent runoff, sedimentation, and the removal of topsoil or vegetation, and to control erosion

- 2.2.52. That within the Oak Ridges Moraine, applications for development or site alteration in a landform conservation area shall be accompanied by the appropriate study as required by the Oak Ridges Moraine Conservation Plan. Planning, design and construction practices for any development or site alteration are required to satisfy the Oak Ridges Moraine Conservation Plan.

- 2.2.54. That mineral aggregate operations are exempt from certain landform conservation requirements in accordance with the Oak Ridges Moraine Conservation Plan.

- 2.2.55. That in considering development and site alteration applications in the Urban Area and Towns and Villages, local municipalities shall consider the importance of adopting planning, design and 
construction practices that will keep disturbance of landform character to a minimum, so as to satisfy the requirements of the Oak Ridges Moraine Conservation Plan.

- 2.2.56. That applications for development and site alteration in an Earth Science Area of Natural and Scientific Interest on Figure 1, or within the related minimum area of influence, shall be accompanied by an earth science heritage evaluation that meets the requirements of the Oak Ridges Moraine Conservation Plan.

\section{Local Municipalities}

- 2.2.53. To require local municipalities to incorporate the Oak Ridges Moraine landform conservation mapping and policies into local official plans. Policies in the local plans shall require that applications for development or site alteration in a landform conservation area identify planning, design and construction practices that will keep disturbance to landform character to a minimum, subject to the requirements established in the Oak Ridges Moraine Conservation Plan. Local municipalities are also encouraged to consider the need for landform conservation planning outside of the Oak Ridges Moraine.

- 2.1.4 Local municipalities to develop policies, initiatives and mapping that protect and complement the system

- 2.1.25 Local municipalities can refine boundaries of the Natural Heritage system/protected countryside (at the time of the conformity exercise) if refinement is supported by a comprehensive natural heritage system study.

- 6.1.3. That local municipalities shall identify the Greenbelt Protected Countryside and the Natural Heritage System in local official plans and determine specific permitted uses to meet the requirements of the Greenbelt Plan and this Plan.

- 6.3.16. To discourage the removal of topsoil and encourage local municipalities to enact by-laws, under the Municipal Act, to regulate the removal of topsoil.

- 6.4.11. To work with the Town of Georgina and others in formulating additional local official plan policies to recognize the unique aspects of the municipally serviced lakeshore areas between the urban area of Keswick and Sutton/Jackson's Point. Such policies will conform to the Greenbelt Plan and the Lake Simcoe Protection Plan and the policy direction of this Plan.

\section{New Community Areas}

- 2.1.10 In new community areas, local official plans shall include policies, initiatives and programs to link/enhance the system through community design and development process. 
- 2.1.12 In new community areas, non motorized trails, community gardens, passive recreational uses, new infrastructure required to service the community, (Stormwater facilities, water/wastewater systems and streets shall be permitted subject to Greenbelt Plan policies and that no other practical location exists for this infrastructure.

- 2.1.13. To require a Regional Greenlands System Plan as a component of secondary plans within new community areas that is consistent with policy 5.6 .14 of this Plan.

\section{Rural Area}

- 6.4.1. To recognize and protect the Rural Area on Map 8, as a natural resource of major importance to the economic and social viability of the Region.

- 6.4.5. That within the Rural Area, applications for redesignation of lands for non-agricultural uses are only permitted if they comply with the Oak Ridges Moraine Conservation Plan, Greenbelt Plan and local municipal official plans. Such applications may require an amendment to this Plan and the local official plan and zoning by-law, demonstrating: d. that there are no negative impacts on key natural heritage or hydrologic features and functions, biodiversity or connectivity of the Regional Greenlands System. (D is also in agriculture protect area).

- 6.4. 7. That new land extensive major recreational uses, such as golf courses and outdoor playing fields, or expansion to these uses, may be permitted in the Rural Area subject to an amendment to this Plan and the local official plan and zoning by-law, where the following provisions are met to the satisfaction of the Region and local municipality:

- c. there is a plan to enhance and improve connections between key natural heritage features and key hydrologic features;

- e. water conservation, wastewater and stormwater management plans that ensure adequate water quality and quantity are submitted; and,

- $f$. the provisions of the Oak Ridges Moraine Conservation Plan, Greenbelt Plan or the Lake Simcoe Protection Plan are met, where applicable.

- 6.4.8 That notwithstanding policy 6.4.5, new cemeteries and accessory uses such as mausolea, columbaria, small scale chapels, expansions of existing cemeteries, but not freestanding places of worship, may be permitted in the Rural Area of the Greenbelt Plan subject to an amendment to this Plan and the local official plan and zoning by-law, where the following provisions are met to the satisfaction of the Region and local municipality:

- g. there is an enhancement plan that demonstrates the use of existing site characteristics, such as 


\begin{tabular}{|c|c|}
\hline & $\begin{array}{l}\text { topography and vegetation, identifies natural native vegetation enhancement and sequential } \\
\text { plantings, including opportunities for memorial groves and the establishment of arboreta, } \\
\text { improvements to connectivity between key natural heritage features and key hydrologic } \\
\text { features, provides for the development of a forest canopy; and, } \\
\text { h. the use conforms with the policies in Chapter } 2 \text { of this Plan. } \\
\text { Summary of Findings (Overall): } \\
\text { Most of the Region's policies around protecting environmentally significant spaces allow development as } \\
\text { long as they are in specific areas and require that additional studies and/or requirements be met to protect } \\
\text { the system. The use of distance from the sensitive area (example: wetland or water shoreline) or minimum } \\
\text { vegetation protection zone distances are utilized in the policies. The only activities that are prohibited from } \\
\text { the system without any exceptions are batching/asphalt plans and new waste disposal sites. }\end{array}$ \\
\hline $\begin{array}{l}\text { Urban forestry program- } \\
\text { policy requiring the planting } \\
\text { and maintaining of trees } \\
\text { specifically to reduce carbon } \\
\text { emissions. }\end{array}$ & $\begin{array}{l}\text { Region/Local municipalities develop Urban Forest Management Plan that may include significant woodland } \\
\text { (2.2.46) } \\
\text { Source: } 2009 \text { GREENING STRATEGY ACHIEVEMENTS - Report No. } 3 \text { of the Transportation Services } \\
\text { Committee Regional Council Meeting of March 25, 2010: } \\
\text { York Region Urban Forest Studies in Vaughan and Markham contribute to a GTA-wide collaboration: In } \\
2009 \text {, two Urban Forest Studies were initiated in partnership with York Region, the Toronto and Region } \\
\text { Conservation Authority, the Town of Markham and the City of Vaughan. These studies place a monetary } \\
\text { and ecological value on the functions of the urban forest (carbon storage, pollutant uptake, energy use } \\
\text { mitigation, etc.). These models have been recognized internationally as critical for directing the } \\
\text { management of the urban forest. In addition to Vaughan and Markham, studies are currently underway in } \\
\text { the City of Toronto, the Town of Pickering, the Region of Peel, with other GTA municipalities considering } \\
\text { undertaking studies in the near future. In December } 2009 \text {, the Region adopted a new Regional Official } \\
\text { Plan. Policy } 2.2 .46 \text { of the Official Plan requires that local municipalities develop an Urban Forest } \\
\text { Management Plan. These urban forest studies provide a strong foundation for the development of an Urban } \\
\text { Forest Management Plan. As Vaughan and Markham urban forest studies wrap up, Richmond Hill is } \\
\text { expected to be the next municipality to initiate a study in partnership with York Region in } 2010 \text {. } \\
\text { Discussions with the Towns of Newmarket and Aurora are also underway. }\end{array}$ \\
\hline
\end{tabular}




\section{Summary of Findings:}

York Region had 22 policies related to conserving energy use. Most of the policies, over half, focused on conserving energy in buildings with a focus on new buildings.

York Region has 7 voluntary policies out of 22 , encouraging local municipalities and developments to exceed energy efficiency standards for existing and all new buildings (5.2.22 and 5.2.27), to provide complementary incentive programs to achieve a successful implementation of LEEDC (Silver, Gold or Platinum standards) buildings across York Region (5.2.24), to undertake municipal-wide Community Energy Plans (5.2.13), to include on-site renewable or alternative energy systems which produce $25 \%$ of building energy use for all new buildings - where on-site renewable or alternative energy systems are not feasible, consideration of purchasing grid-source renewable energy is encouraged $(5.2 .28)$, to encourage all development to incorporate green roofs into building design (5.2.34) and mitigate heat island effects using green or white roofs, strategic planting of trees, and installing light or solar reflecting materials (5.2.35). New community areas are to be designed to reduce urban heat island effects using the options in 5.2.35 (5.6.16).

York Region does require comprehensive secondary plans for Regional Centres and key development areas along Regional Corridors which will include (5.4.6):

(a) policies to ensure excellence in urban design and sustainable construction methods, including winter design;

(b) requirements to reduce and/or mitigate urban heat island effects, by considering the use of green and white roofs, greening to provide shade and light-colored surface materials;

(c) policies that establish urban greening targets, which may be achieved through urban forest canopy, green walls, requirements for on-site greening;

York Region is requiring urban designs to consists of buildings that minimize energy use (5.2.8), expect that all new residential and non-residential buildings have energy efficiency standards, depending on the size of the building (storyes), need to equal an Energy Star standard or be designed to achieve $25 \%$ greater energy efficiency than the Model National Energy Code for Buildings (5.2.20). Policy 5.2.22 encourages that 
industrial buildings be designed to achieve $25 \%$ greater energy efficiency than the Model National Energy Code for Buildings.

York Region requires local municipalities to develop programs to ensure the successful implementation of the sustainable building policies of this Plan (5.2.42) and supports local municipal initiatives in sustainable community planning and sustainable building policy and implementation to achieve building standards greater than the policies of this Plan and the Ontario Building Code (5.2.43). In addition, York Region requires local municipalities to develop Community Energy Plans for each Regional Centre (5.4.24) and one for each new community area to reduce community energy demands, optimize passive solar gains through design, and make use of renewable, on-site generation and district energy options including but not limited to solar, wind, water, biomass, and geothermal energy (5.6.10).

York Region supports renewable and alternative energy systems. The Region permits these systems to be located throughout the Region in accordance with provincial and federal requirements, and that these permissions be incorporated into local official plans and zoning by-laws. Local municipalities shall specify in more detail where renewable and alternative technologies will be permitted (5.2.12). Exceptions are made within the Holland Marsh Specialty Crop Area where provincial and federal requirements will be followed. In addition, within the Greenbelt area where these systems shall be subject to the policies of the Greenbelt Plan and shall be designed to minimize disturbance on agricultural operations (6.3.17).

The Region supports development that will be designed to maximize solar gains and be constructed in a manner that facilitates future solar installations (5.2.26 and 5.6.9)

York wants water and wastewater facilities to be designed and operated to reduce energy use and, where possible, energy recovery (7.3.28) and to incorporate energy-recovery systems into water and wastewater facilities where possible in order to reduce the health and environmental impacts of greenhouse gas and other emissions on air quality (7.3.27).

Outstanding policies: $7.4 .19,7.5 .1,7.5 .2,7.5 .8,7.5 .10 .7 .5 .11,7.5 .12,7.5 .13-16$ in waste tab 6.4.13. That alternative energy systems and renewable energy systems shall be permitted within the Rural Area in accordance with provincial and federal requirements. Any such systems within the Greenbelt Plan Area shall be subject to the policies of the Greenbelt Plan. 
78. To encourage businesses to move towards more energy efficient and effective freight modes and technologies.

\section{Policies to protect and} manage water sources and conserve usage of water.
The Region has recognized the need for various plans to protect, manage and conserve water and their sources. The Region to work with local municipalities, conservation authorities, adjacent municipalities, other agencies and the Province/Federal government to prepare, implement and/or update plans such as Regional Water Strategy, Water Conservation and Efficiency Strategy, Stormwarer Management Master Plans, Comprehensive Master Servicing Plans, York Region 10-Year Water Efficiency Master Plan.

The Region has indicated a need to prepare a Regional water strategy for both piped services and surface and groundwater sources that will include long term protection and conservation strategies, enhancement guidelines and monitoring requirements for streams, lakes, wetlands, groundwater, kettle lakes, Lake Simcoe, and other natural aquatic systems. (2.3.1), and, the development of a long term, innovative strategy for water conservation and efficiency (7.1.19).

To prepare and implement comprehensive stormwater management master plans for each settlement area within the Lake Simcoe Watershed by June 2014 (2.3.39), and comprehensive master environmental servicing plans which will examine all water systems in a comprehensive and integrated manner to understand the integration of all water systems to increase efficiencies, maximize water conservation in buildings and municipal infrastructure, including water-efficient landscaping and rainwater collection for reuse and to minimize stormwater volume and contaminant loads, and maximize infiltration through an integrated treatment approach, which may include techniques such as rainwater harvesting, runoff reduction of solids and materials at source, phosphorus reduction, constructed wetlands, bioretention swales, green roofs, permeable surfaces, clean water collection systems, and the preservation and enhancement of native vegetation cover (5.6.11). And to implement stormwater management initiatives $(2.3 .36)$.

To update and implement the York Region 10-Year Water Efficiency Master Plan to ensure long term water efficiency, conservation, cost savings, and public education $(7.1 .20)$, and to regularly update water and wastewater service planning through the Master Plan process and to co-ordinate infrastructure and phasing 
growth by $(7.3 .1)$ :

a. undertaking groundwater studies to support source water protection planning;

b. regularly evaluating existing infrastructure;

c. using a 40- to 50-y ear time horizon to ensure full life cycle infrastructure planning and costing:

d. considering the value of ecological services in all infrastructure investment decisions;

e. investigating new technologies and sustainable innovative practices; and,

f. providing implementation and phasing plans including the York Region 10-Year Capital Plan.

To implement watershed plan objectives that protect and enhance river system function, achieve water quality/quantity in Urban and new community areas, address long term cumulative impact of development on watershed through regular monitoring, reporting and adaptive management, to protec/enhance existing geology... etc., provide guidelines for sustainable development/construction, retrofit exiting neighborhoods to ensure better hydrologic function $(2.3 .33)$.

To assist local municipalities in the review and approval of site management and contingency plans as required by the Oak Ridges Moraine Conservation Plan to ensure that land uses do not pose a significant threat to Regional wells in the Oak Ridges Moraine (7.3.47). To regularly review and update sustainable building incentive programs within York Region together with local municipalities. These programs may include water and wastewater servicing allocation credils, density bonusing, expedited processing of development approvals or the use of local municipal community improvement plans and associated financial tools $(5.2 .25)$.

Last, to implement Fisheries Management Plans with province and conservation authorities (2.3.10)

The Region had indicated that the natural quality and characteristics of watercourses, lakes, aquatic habitat... etc be maintained and development be designed with the goal of maintaining water balance (2.3.2), and that linkages and related functions among different water systems are to be maintained (2.3.3). The Region wishes to provide high-quality, safe, and clean drinking water while protecting surface and groundwater resources by (7.3.19):

a. meeting and exceeding water quality standards defined by the Safe Drinking Water Act; b. protecting the drinking water supply through source water protection strategies; 
c. protecting and enhancing the Region's system of lakes, rivers and streams:

d. ensuring groundwater use sustains the long term health of aquifers:

e. maintaining and updating the groundwater monitoring program; and,

f. identifying source water protection areas.

Summary of Findings: York Region portfolio of water protection, management and conservation consists of various "directions" including considering incompatible uses, restricting development and land uses around water sources, implementing various techniques and investigating new technologies, and improving water and waste water facilities. The most common policies were around creating plans (described earlier), suggesting techniques on how to protect and conserve water and the sources followed by restricting activities or land use designations.

The Region will prepare water source protection plans with Province, local municipalities, and conservation authorities to protect the quality and quantity of Regional water supply from incompatible uses and sources of contamination to protect water supply from incompatible uses and sources of contamination (2.3.7). The Region requires local official plans to identify all Regional wells and intake protection zones to protect drinking water quality (7.3.9).

In Wellhead Protection Areas outside of the Oak Ridges Moraine, a Risk Assessment shall be conducted as prescribed by the Clean Water Act, 2006, and a Risk Management Plan developed and approved prior to the establishment of new land uses that involve the storage or manufacture of (7.3.39);
a. petroleum-based fuels and or solvents;
b. pesticides, herbicides, fungicides or fertilizers;
c. construction equipment:
d. inorganic chemicals;
e. road salt and contaminants as identified by the Province;

$f$. the generation and storage of hazardous waste or liquid industrial waste, and waste disposal sites and facilities;

g. organic soil conditioning sites and the storage and application of agricultural and non-agricultural source organic materials: and,

h. snow storage and disposal facilities. 
In addition, existing land uses in the same area as 7.3.39 and in areas high potential for groundwater contamination, involve the storage, manufacture or use of materials detailed in policy 7.3.39, a Risk Assessment and a Risk Management Plan may be required (7.3.41).

Wellhead Protection Areas within the Oak Ridges Moraine with new land uses which involve the storage, manufacture of materials or uses detailed in policy 7.3.39 are prohibited (7.3.45). Furthermore, the Region will investigate whether there is a need to undertake risk management planning, including spills response, contaminant recovery, aquifer rehabilitation plans and public education in consultation with other partners, where existing land uses involve the storage of contaminants identified in policy 7.3.39 in Wellhead Protection Areas (7.3.44).

The Region prohibits the storage or use of pathogen threats by new land uses, including the siting and development of stormwater management ponds and rapid infiltration basins or columns, except for the storage of manure for personal or family use, within the 100-metre pathogen zone around each municipal well as shown on Map 6 and may be restricted within the 100-metre to 2-year time of travel (7.3.42).

And unless a Risk Assessment and Risk Management Plan has been undertaken to the satisfaction of the Region, the expansion of existing incompatible land uses within the 100-metre pathogen zone is prohibited and the expansion of existing incompatible land uses within the 100-metre to 5-year time of travel zone will be discouraged. Redevelopment of these uses to more compatible uses is encouraged, subject to an appropriate Risk Assessment and a Risk Management Plan (7.3.43).

The Region also prohibits undertaking of animal agriculture and the storage of agricultural equipment for other than personal or family use for new uses within the Oak Ridges Moraine, in the 0-to-2 year time of travel zone the storage of animal manure (7.3.46).

Lastly, the Region prohibits or restricts the generation and storage of the following, in areas of high Aquifer Vulnerability (7.3.50):

a. hazardous waste or liquid industrial waste;

b. waste disposal sites and facilities;

c. organic soil conditioning sites and snow storage and disposal facilities;

d. underground and above ground storage tanks that are not equipped with an approved secondary containment device; and,

e. storage of a contaminant listed in Schedules to Ontario regulations. 
The Region focuses on directing development away from sensitive surface and groundwater water features (2.3.4). Many of the policies restrict development to specific areas, away from sensitive water sources and/or require additional studies to demonstrate that there will be no negative impacts to the area $(2.3 .5$, 7.3.10, 7.3.49). It requires that development have an integrated and innovative approach to water management, be water efficient, and minimize stormwater volumes and contaminant loads and maximize infiltration through an integrated treatment approach, which may include techniques such as rainwater harvesting, runoff reduction of solids and materials at source, constructed wetlands, bioretention swales, green roofs, permeable surfaces, clean water collection systems, and the preservation and enhancement of native vegetation cover (5.2.11). And that development within and expansions to the urban uses within Towns and Villages identified on Map 1 will occur on the basis of full municipal water and wastewater treatment services where such facilities currently exist. For existing or previously approved development in Towns and Villages, water and wastewater treatment services will be continued where feasible and in keeping with the provisions of local official plans and this Plan (7.3.15). Lastly, any major development on the Oak Ridges Moraine to conform with watershed plan (2.3.35) and Lake Simcoe watershed located outside of the Oak Ridges Moraine and Greenbelt cannot have new mineral aggregate ops, wayside pits, quarries, ancillary or accessory uses unless permitted in the Lake Simcoe Protection Plan (2.1.24).

In addition to plans, restricting uses and development, York Region has a number of policies which offer ways to further protect, enhance and conserve water resources, they include establishing procedures for water taking permits (2.3.12), encouraging agricultural land management practices that minimize the application of pesticides and nutrients as well implementing best management practices for integrated pest management, phosphorus reduction, nutrient management and soil and water conservation (2.3.14 and $6.3,14$ ), expecting that the owners and operators of stormwater management works inspect, maintain and monitor effluent quality on a periodic basis (2.3.38), encouraging the use of water efficient, drought resistant landscaping by providing a minimum of 6 inches of topsoil, installing drought resistant sod, providing landscape features that minimize the demand for water and synthetic chemicals by utilizing native and drought resistant species and installing permeable driveway surfaces $(5,2.33)$, pursue the implementation of water efficiency innovations such as water reuse systems, rainwater harvesting and innovative stormwater management (7.1.22), to reduce the amount of water used in the Region's construction projects (7.1.24), to protect surface water quality by addressing, both point and non-point 
sources of pollution in partnership with local municipalities and conservation authorities (7.3.21), to encourage local municipalities to promote safe and effective maintenance of individual private wastewater systems in order to protect and improve groundwater and surface water quality (7.3.22).

Additional policies supporting the protection and conservation of water resources include:

1. Further studies to analyze and monitor water quality (2.3.8 and 2.3.9), to investigate the full cost pricing of water (7.1.21), to investigate wastewater treatment new technologies (7.3.20), to update wellhead studies and modeling at least every 5 years to refine the location and extent of Wellhead Protection Areas for all municipal wells. Changes to Wellhead Protection Areas or policies will require an amendment to this Plan (7.3.38)

2. Improvements to water and waster water facilities:

- 7.3.32. That water and wastewater services will be planned, constructed and operated in a manner that protects, enhances, and provides net benefit to the Region's natural and cultural heritage.

- 7.3.25. To ensure that wastewater effluent is managed to minimize impacts on the quality of the receiving water.

- 7.3.26. To ensure that biosolids resulting from wastewater treatment are managed sustainably.

- 7.3.34. That the water and wastewater systems be sized to consider the potential for expansion of the service area, intensification and increased allocation where permitted by York Region Master Plans and Provincial Plans.

- 7.3.24. To work with local municipalities to reduce the amount of inflow and infiltration in both local and Regional wastewater systems.

- 7.1.23. To investigate innovative wastewater treatment technologies and approaches including grey water reuse, naturalized wastewater treatment and water recycling in residential, commercial, institutional and industrial uses.

3. To prepare comprehensive master environmental servicing plans as a component of secondary plans and major development or re-development to minimize stormwater volume and contaminant loads, and maximize infiltration through an integrated treatment approach, which may include techniques such as rainwater harvesting, runoff reduction of solids and materials at source, phosphorus reduction, constructed wetlands, bioretention swales, green roofs, permeable surfaces, clean water collection systems, and the preservation and enhancement of native vegetation cover (2.3.37). Similar comprehensive secondary plans are required for Regional Centres and key development areas along 
Regional Corridors (5.4.6). To prepare comprehensive master environmental servicing plans as part of secondary plans to protect and enhance water systems (2.3.13)

4. Management of Lakes:

- That within the Greenbelt Plan Area the Towns or Villages that do not currently have Lake Ontario or Lake Simcoe based water and wastewater services, extensions to or expansions of existing lakebased services is prohibited, unless the servicing is required to address failed individual on-site sewage or water services or to ensure protection of public heal th as determined by the Medical Officer of Health. (5.6.19).

- 7.3.12. To supply the Urban Area and Towns and Villages with water from the Great Lakes or from Lake Simcoe, subject to the restrictions of the Greenbelt Plan, Lake Simcoe Protection Plan, or other Provincial plans and statutes. A limited amount of groundwater resources will be used and managed in a way that sustains heal thy flow into creeks, streams and rivers.

- 7.3.13. To support the Great Lakes water balance by continuing to invest in Lake Ontario based infrastructure, and ensuring that water removed from Lake Ontario is returned at an equivalent or better quality.

- 7.3.23. that no new on site wastewater system will be permitted within 100 meters of the Lake Simcoe Shoreline, other lakes, or any permanent streams within the Lake Simcoe watershed except as provided for under the provisions of the Lake Simcoe Protection Plan.

5. Water efficient buildings:

- 5.2.21. To require that all new buildings achieve $10 \%$ greater water efficiency than the Ontario Building Code

- 5.2.23. To encourage that all new buildings achieve $20 \%$ greater water efficiency than the Ontario Building Code. Natural Resources Canada

- 5.2.22. To encourage the following energy efficiency standards for new buildings:

- Grade-related (3 storeys or less) residential buildings achieve performance level that is equal to a rating of 83 or more when evaluated in accordance with Natural Resources Canada's EnerGuide for New Houses: Administrative and Technical Procedures.

- Mid- and high-rise residential (4 storeys and greater) and non- residential buildings be designed to achieve $40 \%$ greater efficiency than the Model National Energy Code for Buildings. 
$\circ$ Industrial buildings be designed to achieve $25 \%$ greater energy efficiency than the Model National Energy Code for Buildings.

- 5.2.23. To encourage that all new buildings achieve $20 \%$ greater water efficiency than the Ontario Building Code.

- 5.2.24. To encourage that new buildings be designed and certified to LEEDO Silver, Gold or Platinum standards, and to provide complementary incentive programs to achieve the successful implementation of LEEDC buildings across York Region.

- 5.2.27. To encourage retrofitting of existing buildings within the Urban Area and within Towns and Villages to the standards in 5.2 .22 and 5.2 .23 of this Plan.

- 5.2.32. To require the installation of rainwater harvesting and re-circulation/re-use systems on all new residential buildings for outdoor irrigation and outdoor water use.

6. Plan Water Services and Land use together:

- 7.3.2. To ensure that the provision of appropriate water and wastewater infrastructure and servicing capacity is co-ordinated with plans of subdivision, plans of condominium, site plans or any other development applications in order to ensure services are avallable prior to occupancy.

- 7.3.3. To plan water and wastewater services to ensure co-ordinated land use approvals, capital plans and master plans.

- 7.3.4. That the provision of water and wastewater servicing within communities be co-ordinated with land use planning approvals to:

- achieve complete communities;

- achieve balanced communities with residential and employment opportunities;

- assist in the sequencing of growth within communities;

achieve intensification targets;

promote energy efficient green buildings; and,

- capitalize on intensification and more compact development opportunities as they arise. "

Last, all improvements or new water and wastewater infrastructure systems located within the Oak Ridges Moraine, Greenbelt, and Lake Simcoe watershed, shall conform with the Oak Ridges Moraine Conservation Plan, the Greenbelt Plan or the Lake Simcoe Protection Plan (7.3.16). That in the case of a conflict between the Wellhead Protection Area policies in this Plan and the Oak Ridges Moraine Conservation Plan policies, the more restrictive policies shall apply (7.3.48). And that the Province or Federal government consider standards for new technologies which could impact the protection of drinking water, such as ground source 
And local municipalities are directed by the Region to:

- Establish policies and programs to protect, enhance and monitor water systems (2.3.11)

- Incorporate Wellhead Protection Area policies and mapping into local official plans and zoning by-laws (7.3.36)

- Local municipal official plans contain mapping and policies that prohibit or restrict uses in areas of Aquifer Vulnerability in accordance with the requirements of the Oak Ridges Moraine Conservation Plan $(7.3 .51)$.

\section{Additional Policies:}

- 6.4. 7. That new land extensive major recreational uses, such as golf courses and outdoor playing fields, or expansion to these uses, may be permitted in the Rural Area subject to an amendment to this Plan and the local official plan and zoning by-law, where the following provisions are met to the satisfaction of the Region and local municipality:

- e. water conservation. wastewater and stormwater management plans that ensure adequate water quality and quantity are submitted; and,

- 6.4.8 That nowithstanding policy 6.4.5, new cemeteries and accessory uses such as mausolea, columbaria, small scale chapels, expansions of existing cemeteries, but not freestanding places of worship, may be permitted in the Rural Area of the Greenbelt Plan subject to an amendment to this Plan and the local official plan and zoning by-law, where the following provisions are met to the satisfaction of the Region and local municipality:

- e. appropriate hydrological and hydrogeological studies have been completed, which indicate that the use will not have adverse impacts on the quality and quantity of ground and surface water on or nearby the site or a Wellhead Protection Area;

7.2.76. To consider restrictions on the haulage of chemicals and volatile materials in Wellhead Protection Areas, shown on Map 6, and Areas of High Aquifer Vulnerability, shown on Map 7.

7.3.6. To provide full municipal water and wastewater servicing to accommodate grow th in the Urban Area. 7.3.7. To consider alternatives to servicing northern York Region in keeping with the requirements of the Environmental Assessment Act. the York Region Water and Wastewater Master Plan and the Upper York Scrvicing Solution lndividual Environmental Assessment.

7.3.11. That where the protection of public health is an issue. in areas of existing groundwater 
Green procurement municipal contracts with environmentally responsible management practices.

Policies on reducing waste generated through an integrated waste management:

- recycling and reuse of waste generated programs (household solid, industrial or commercial and hazardous waste) contamination as determined by a Medical Officer of Health, and where full municipal water and wastewater services cannot be provided, communal water supply and wastewater treatment systems may be considered. Consideration of communal systems shall be reviewed in the context of suitable administrative and financial arrangements to the satisfaction of the Region and the Province.

7.3.35. That the Wellhead Protection Areas shown on Map 6 are based on time of travel zones as follows:

a. a 100-metre pathogen zone around each wellhead; and,

b. time of travel zones of 0 to 2 years, 2 to 5 years, 5 to 10 years and 10 to 25 years.

7.3.37. To update this Plan to identify Intake Protection Zones and policies for Keswick and Sutton to protect the quality and quantity of the water supply.

7.4. 16. To pursue environmentally responsible purchasing practices for Regional operations and services.

7.4.18. To require that the Region and its contractors follow socially and environmentally responsible waste management practices.

The Region of York established the following waste management targets (7.4.2):

a. Achieving at least $80 \%$ diversion from landfill by 2010 ;

b. Achieving over $90 \%$ diversion from landfill by 2016 ; and,

c. Eliminating the disposal of unprocessed waste in landfill by 2020 .

In addition, it plans to achieve ISO 14001 environmental management system certification for Regional waste operations by 2012 (7.4.8). The Region plans to develop a York Region Waste Management Master Plan based on a sustainable life-cycle approach containing comprehensive strategies to reduce, reuse, recycle, and recover all forms of waste in York Region (7.4.1) and to develop monitoring tools and operational policies in support of achieving substantial waste reduction in Regional operations and services (7.4.17). It wants to investigate ways to reduce, reuse, recycle, and recover waste in Regional functions and facilities and incorporate reused or recycled material in operations and maintenance (7.4.15) and to pursue innovative energy-from-waste technologies (7.4.19). Lastly, the Region requires that the Region and its contractors follow socially and environmentally responsible waste management practices (7.4.18) and wants to pursue partnerships with local municipalities and other jurisdictions for shared infrastructure and resources to optimize efficiencies and provide consistent waste management programs across municipal boundaries (7.4.20).

The Region wants to work towards three-stream waste collection in Regional facilities (7.4.11) and ensure that facilities necessary for three-stream waste separation and collection are provided consistent with policy 
7.4.9 of this Plan (5.2.38). Policy 7.4.9. requires that all new multi-unit residential buildings incorporate three-stream waste collection capabilities. The Region to work

with local municipalities to require existing multi-unit residential buildings to participate in three-stream waste collection (7.4.10).

Lastly, The Region wants to promote local solutions for waste management and ensures that the location of any new solid waste management facility has regard for public health and environmental impacts (7.4.21).

The Region encourages the industrial, commercial and institutional sectors to develop waste reduction programs that support York Region's diversion goals (7.4.12) as well as the Province to require waste reduction programs in the industrial, commercial and institutional sectors (7.4.13). Furthermore, the Region encourages the Province and Federal government to provide comprehensive packaging reduction and extended producer responsibility legislation that supports the goal of waste prevention (7.4.3).

Lastly, the Region wants to ensure that all new development reduces construction waste and diverts construction waste from landfill is consistent with policy 7.4.14 of this Plan (5.2.37), while policy 7.4.14 encourages the diversion of construction and demolition waste to meet or exceed the Region's diversion targets.

\section{Summary of Findings:}

The Region is working towards a three-stream collection system in the residential buildings and plans to encourage the business sectors to join in. The focus is also on reducing construction waste. In addition, policies include targets, monitoring the achievement of targets, reaching out to the other level governments to encourage waste reduction and to work with other stakeholders.

\section{Additional policies:}

5.2.30 - To encourage the use of environmentally preferable materials including low volatile organic compound products, adhesives and finishes, high- renewable and recycled content products and certified sustainably harvested lumber in all new development - plays a role in reducing hazardous wastes.

3.2. 4. To investigate strategies related to reducing the industrial use of toxic materials in consultation with provincial, municipal and business partners. 
Transportation demand management - policy encouraging the reduction of automobile use through the application of traffic control, public parking and public transit and road strategies.
To reduce vehicle emissions by ensuring that communities are designed to prioritize pedestrians and cyclists, reduce single occupancy automobile use, and support public transit and transportation demand management initiatives (3.2.3).

\section{Public parking:}

- Secondary plans and zoning by-laws shall incorporate parking management policies and standards that include (5.2.10 and 5.4.8):

- reduced minimum and maximum parking requirements that reflect the walking distance to transit and complementary uses;

- shared parking requirements, where possible, reflecting variances in parking demand between complementary uses on a time-of-day, weekday/weekend, and monthly basis;

o on-street parking;

- site design that orients the main building entrance(s) towards the street(s), that does not permit the placement of surface parking spaces between the main building entrance and the major street;

- preferential locations for carpooling and car-sharing spaces and bicycle storage requirements.

- To establish a long term parking management within the Regional Centres (5.4.26):

- a system of municipal parking authorities to develop and/or operate shared public parking facilities;

o cash-in-lieu-of-parking policies; and,

the planning for parking in structured or underground facilities in the final phasing of all site development.

- To manage the supply of parking in Regional Centres and Corridors, consistent with the policies in Section 5.4 of this Plan (7.1.3) and to work with local municipalities to develop a co-ordinated approach to parking and parking management, consistent with the parking policies in Chapter 5 of this Plan $(7.1 .5)$.

\section{Public Transit:}

- To work with local municipalities to update the York Region Transit- Oriented Development Guidelines to provide greater emphasis on trip reduction (7.1.6). 
- To require that new institutional, commercial and industrial development applications include a transit demand strategy that consider preferential carpool parking, bicycle facilities, employee transit passes, and alternative work arrangements (7.1.9) and to work with institutional, commercial and industrial employers to undertake transit demand strategies (7.1.10).

- To develop a discounted university and college transit pass program with educational institutions (7.1.16).

- To achieve higher transit usage by supporting improvements in service, convenient access and good urban design, including the following (7.2.25):

- minimizing walking distance to planned and existing transit stops through measures such as the provision of walkways, sidewalks and more direct street patterns. The Region will plan to provide transit service so that the distance to a transit stop is within 500 meters of $90 \%$ of residents, and within 200 meters of $50 \%$ of residents in the Urban Area;

- connecting transit stops directly to sidewalks and adjacent buildings in the Urban Area;

- providing bus bays, transit shelters and bus loops with sufficient lighting and accessibility features;

- directing medium- and high-density urban development to rapid transit corridors;

- creating a system of parking and drop-off facilities for commuters;

- providing intermodal terminals or hubs;

- providing transit service on mid-block collectors;

giving priority to pedestrian and cycling access to transit through the planning and development approval process;

- utilizing the York Region Transit-Oriented Development Guidelines and related tools in the review and evaluation of development applications and related studies; and,

- requiring all new development applications to prepare a mobility plan and demonstrate the proposal's approach to transit.

- To implement transit improvements on urban streets as identified on Map 12, which may include transit lanes, high-occupancy vehicle lanes, queue jump lanes, bicycle lanes and other transit signal priority needs (7.2.41).

- That mobility plans shall be completed to ensure that (5.6.12):

- communities are designed to have interconnected and accessible mobility systems, with a priority on pedestrian movement, and on transit use and access;

o communities are designed to include a system of pedestrian and bicycle paths linking the 
community internally and externally to other areas, and providing access to the transit system;

- a transit plan is completed in consultation with York Region Transit, which identifies transit routes and corridors, co-ordinates transit with land use patterns and ensures the early integration of transit into the community;

- the distance from a transit stop is generally no more than 500 meters for $90 \%$ of the population, and no more than 200 meters for $50 \%$ of the population;

- all schools and community centres shall be integrated into the community mobility system and provide the ability to walk, cycle, transit and carpool to these locations;

- the street network includes continuous collector streets that run both north-south and east-west and/or a grid system of streets linked to the Regional Street network;

- new community areas are designed to meet the York Region Transit-Oriented Development Guidelines;

- a rapid transit corridor and/or transit terminal that connects to a rapid transit corridor is included in the community;

$\circ$ parking standards, consistent with policy 5.2.10, encourage and support transit use and include reduced minimum and maximum parking standards; and,

- trip-reduction strategies consistent with the policies of Section 7.1 are promoted.

\section{Road Strategies:}

- To require that appropriate transportation demand management measures to reduce single occupancy automobile trips are identified in transportation studies and in development applications (7.1.1)

- To partner with the Province and Metrolinx to provide transit service to carpool lots along 400-series highways (7.1.13).

- To provide preferential treatment for transit vehicles on Regional streets, including the construction of high-occupancy vehicle lanes, dedicated transit lanes, transit signal priority and other transit priority measures (7.2.24).

- To require transit or high-occupancy vehicle lanes and bicycle lanes within the right-of-way of 6-lane Regional streets (7.2.42)

- To encourage the planning and implementation of high-occupancy vehicle lanes on all 400-series highways within and/or adjacent to York Region (7.2.43). 


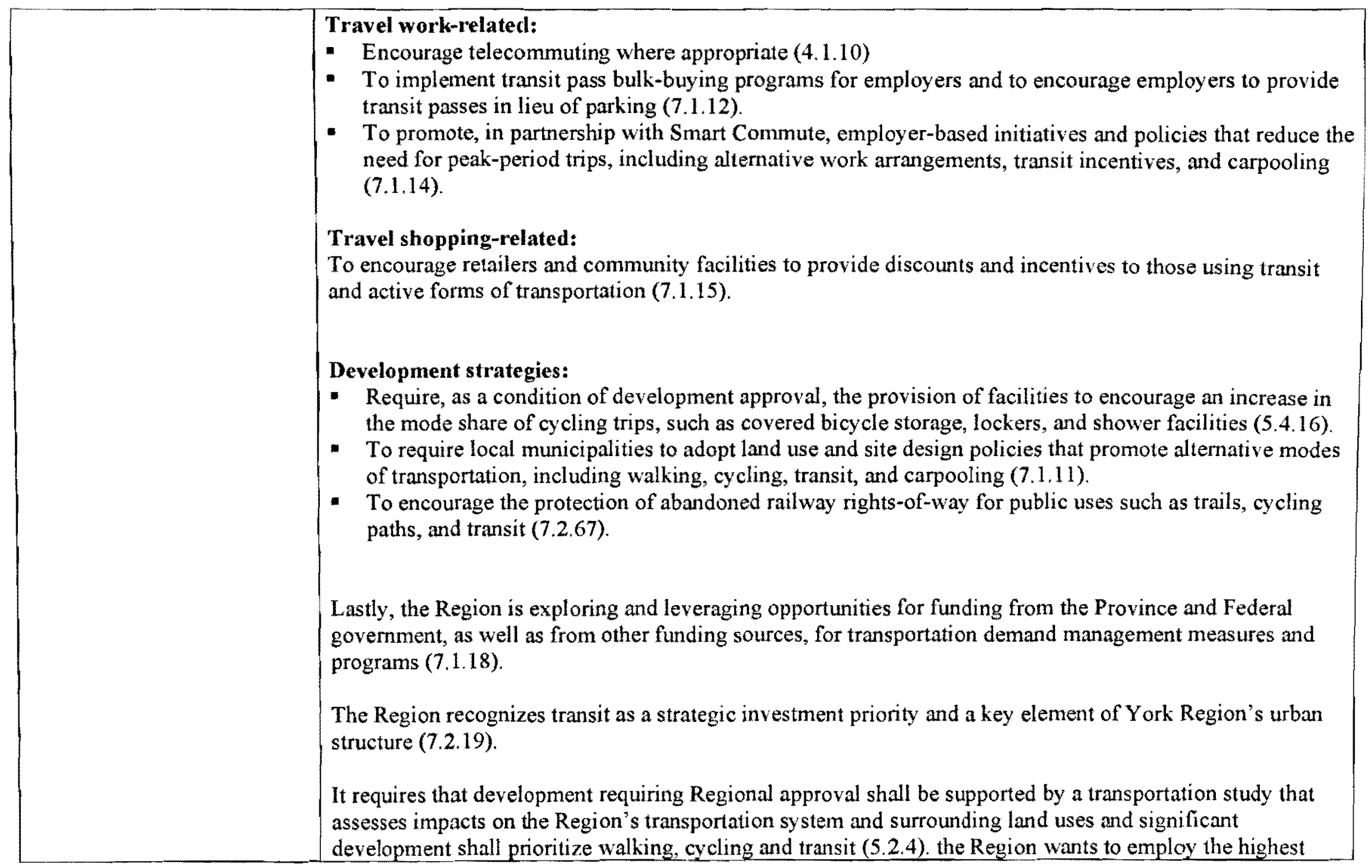


The Region's target for the distance to a transit stop be generally no more than 500 meters (a 5-to-10-minute walk) for $90 \%$ of the residents and no more than 200 meters for $50 \%$ of residents (5.3.4). It also expects to achieve an overall transit modal split of $30 \%$ during peak periods in the Urban Area and $50 \%$ in the Regional Centres and Corridors by $2031(7.2 .26)$.

The Region's focus is on the development of transit corridors and related infrastructure necessary to establish the York Region Transit and Viva network as illustrated on Map 11 (7.2.21). To co-ordinate the planning, integration and operation of existing and new transit services with local municipalities, the Toronto Transit Commission, the Province, Metrolinx and adjacent municipalities (7.2.37) and to work with local municipalities, the Toronto Transit Commission, Metrolinx and adjacent municipalities to encourage the Province and the Federal government to provide sustainable capital and operational funding and tools to support transit (7.2.38).

And lastly, to work with partners to complete the transit network, as illustrated on Map 11, including subway line extensions, Metrolinx enhancements, the 407 Transitway and other rapid transit corridors (7.2.22), so that it can be implemented $(7.2 .31,7.2 .32,7.2 .36)$. The Transit Network is described in a number of supporting documents, they are (7.2.33):

a. approved environmental assessments or approved transit project assessments;

b. the York Region Transit 5-Year and annual Service Plans;

c. the York Region Transportation Master Plan;

d. Regional Rapid Transit Standards;

e. the Regional Rapid Transit Network Plan; and,

f. the Pedestrian and Cycling Master Plan.

Policies 5.3.4 and 7.2.26 indicate the distance from transit to a location, and policy 7.2 .25 aim to achieve higher transit usage by directing medium- and high-density urban development to rapid transit corridors are the only policies explicitly stating that public transit will be located in higher densities but there is no mentioned of public transit being located in smart development districts (key words are: mix use, common/public spaces, recreational facilities). 
Additional policies:

5.3.11. That human services facilities be located in close proximity to public transit.

5.4.31. That the most intensive and widest range of uses within the Regional Corridors be directed to specific intensification areas, identified by local municipalities as key development areas. These areas shall include the following segments of the Regional Corridor:

- Lands within a reasonable and direct walking distance from all planned subway stations, and select rapid transit stations as identified by local municipalities;

- Major transit station areas immediately adjacent to transit stations and terminals, including GO Transit; and,

- Large and/or contiguous properties that are under-utilized, and are appropriate and desirable locations for redevelopment or intensification.

5.4 .32 . That secondary plans, consistent with criteria in policy 5.4 .6 , shall be prepared by local municipalities for the following key development areas:

- All planned subway stations outside of the Regional Centres;

- Lands immediately adjacent to transit terminals, including GO Transit terminals and gateway hubs; and,

- Other key development areas identified by local municipalities.

5.6.12. That mobility plans shall be completed to ensure that:

a. communities are designed to have interconnected and accessible mobility systems, with a priority on pedestrian movement, and on transit use an $\mathrm{d}$ access;

b. communities are designed to include a system of pedestrian and bicycle paths linking the community internally and externally to other areas, and providing access to the transit system; c. a transit plan is completed in consultation with York Region Transit, which identifies transit routes and corridors, co-ordinates transit with land use patterns and ensures the early integration of transit into the community;

d. the distance from a transit stop is generally no more than 500 meters for $90 \%$ of the population, and no more than 200 meters for $50 \%$ of the population;

e. all schools and community centres shall be integrated into the community mobility system and provide the ability to walk, cycle, transit and carpool to these locations;

f. the street network includes continuous collector streets that run both north-south and east-west and/or a grid system of streets linked to the Regional Street network;

g. new community areas are designed to meet the York Region Transit-Oriented Development 
Pedestrian access plan policies with an integrated plan of walkways for the purpose of improving pedestrian safety and access to neighborhood and community points of employment, home and leisure - which is incorporated with the transit support development and transit demand management
Guidelines;

h. a rapid transit corridor and/or transit terminal that connects to a rapid transit corridor is included in the community;

i. parking standards, consistent with policy 5.2.10, encourage and support transit use and include reduced minimum and maximum parking standards; and,

j. trip-reduction strategies consistent with the policies of Section 7.1 are promoted. "

5.4.14. To require innovative approaches for the delivery of infrastructure that support city building in Regional Centres and Corridors, including:

a. working with utility providers to ensure appropriate utility design and placement, including burying cables and structures, consistent with Transit-Oriented Design guidelines for Regional Centres and Corridors; and,

b. transit and surface and sub-surface subway infrastructure, including transformer stations, vent shafts, turning loops, transit stations and emergency exits.

7.2.51. To restrict vehicle access from developments adjacent to Regional streets to maximize the efficiency of the Regional street system through techniques such as suitable local street access, shared driveways and interconnected properties. Exceptions may be made to this policy in Regional Centres and Corridors, and mainstreets.

7.2.82. To support efficient transportation connections, including transit, streets and rail, from York Region to both Toronto Pearson International Airport and the proposed Pickering Airport.

3.1.3. To require high-quality urban design and pedestrian-friendly communities that provide safety, comfort and mobility so that residents can walk to meet their daily needs.

5.2.8. To employ the highest standard of urban design, which: a. provides pedestrian scale, safety, comfort, accessibility and connectivity; f. emphasizes walkability and accessibility through strategic building placement and orientation;

7.2.29. To encourage the provision of sidewalks and street lighting on all streets in York Region.

7.2.54. To work with local municipalities to complete missing sidewalk links on Regional streets in the Urban Area. 
Bicycle access plan - policies with an integrated plan of bicycle trails, bike lanes and road crossing which is incorporated with the transit support development and transit demand management

Walk and Bicycle - part of Transport Management policies
7.2.4. To develop an integrated Regional cycling network connecting people to places of recreation, services and employment and transit.

7.2.12. To encourage property owners to provide facilities such as benches, shelters and secure bicycle storage at major destinations, including employment, educational, institutional and shopping locations.

7.2.1. To implement the Regional Cycling Network shown on Map 10.

5.4.6. That comprehensive secondary plans for Regional Centres and key development areas along Regional Corridors be prepared by local municipalities and implemented in co-operation with the Region and related agencies. These secondary plans shall include: $n$. a mobility plan that addresses the criteria in policy 5.6.12 in this Plan with an emphasis on delivering a weather-protected system of pedestrian and cycling paths and facilities;

5.6.13. That new community areas shall be designed to implement the York Region Pedestrian and Cycling Master Plan.

7.2.2. To update the York Region Pedestrian and Cycling Master Plan at least every 5 years, concurrent with the 5-year review of this Plan.

7.2.5. To provide safe, comfortable and accessible pedestrian and cycling facilities that meet the needs of York Region's residents and workers, including children, youth, seniors and people with disabilities.

7.2.6. To partner with local municipalities and other stakeholders to implement pedestrian and cycling programs.

7.2.7. To work with local municipalities to co-ordinate infrastructure within Regional rights-of-way for operating and capital components, including street lighting, sidewalks and cycling facilities.

7.2.13. To co-ordinate Regional and local pedestrian and cycling networks with trail connections to the Regional Greenlands System trails network, where appropriate.

7.2.15. To encourage the development and implementation of local municipal pedestrian and cycling master plans.

3.3.5. To ensure that public buildings and facilities are designed to be accessible, and are located in proximity to pedestrian, cycling and transit systems.

Walk/Bicycle/Transit - part of Transport Management policies
5.2.3. That communities be designed to ensure walkability through interconnected and accessible mobility systems. These systems will give priority to pedestrian movement and transit use, provide pedestrian and cycling facilities, and implenent the York Region Pedestrian and Cycling Master Plan. 
7.2.9. To ensure the safe year-round operation of Regional pedestrian, cycling and transit facilities through design, signage, enforcement and effective maintenance

7.2.11. To integrate pedestrian, cycling and transit activities through improvements such as bicycle racks and storage at transit stops, bicycle racks on buses, and improved access for pedestrians and bicycles at transit stops, stations and terminals.

7.2.16. To partner with the York Region District and Catholic School Boards to implement the Active and Safe Routes to School program, and to design and locate school campuses to promote walking, cycling and transit as a primary means of transportation.

7.2.18. To encourage the Province and Federal government to provide funding and tools to support the development and promotion of active transportation as part of a healthy, active lifestyle.

7.2.27. To work with local municipalities to provide multi-use paths, sidewalks and street lighting along Regional streets serviced by transit.

7.2.53. To require local municipalities to design street systems to accommodate pedestrian, cycling and transit facilities.

7.2.34. To manage the movement of traffic in the Regional Rapid Transit Corridors shown on Map 11 to improve the safety and efficiency of all movements including that of pedestrians, cyclists and transit vehicles.

\section{Summary of Findings:}

Most of the Region's policies focus on integrating pedestrian, cycling and transit systems. It was found that 9 consider the three means of transportation together when designing safe, accessible and integrated communities. These policies focused on making sure buildings and facilities are designed to be accessible and located in proximity to pedestrian, cycling and transit systems (3.3.5), that communities are designed to ensure walkability through interconnected and accessible mobility systems (5.2.3), ensure that pedestrian, cycling and transit facilities are safe and accessible year-round (7.2.9), that improvements are made at transit stops, stations and terminals such as bicycle racks and storage at transit stops and bicycle racks on buses (7.2.11). The Region also to partner with Catholic School Boards to implement safe routes to school and design and locate schools to promote walking, cycling and transit as a primary means of transportation (7.2.18), and design communities with multi-use paths, sidewalks and street lighting along Regional streets serviced by transit $(7.2 .53)$.

It was found that 7 policies integrated pedestrian and cycling systems. They called for the implementation 
and regular review of the York Region Pedestrian and Cycling Master Plans $(5,6,13,7.2 .2)$, to provide for safe, comfortable and accessible pedestrian and cycling facilities that meet the needs of all residents including children, youth, seniors and people with disabilities (7.2.5) and to work with local municipalities to co-ordinate infrastructure to include street lighting, sidewalks and cycling facilities (7.2.7) and to implement pedestrian and cycling programs (7.2.6). Lastly, The Region will co-ordinate pedestrian and cycling networks for them to be connected to trails in the Regional Greenland System (7.2.13).

It was found that about 3-4 policies focused solely on pedestrian access plan or bicycle access plan. These policies focused solely on, either the pedestrian or bicycle - safety, accessibility and connectivity to places of recreation, services and employment, transit - so that residents can walk or bike to meet their daily needs.

3.4.9. To encourage access to core historic areas by walking, cycling and transit, and to ensure that the design of vehicular access and parking complements the historic built form.

\subsubsection{4 to increase public awareness of watershed health and protection (resource conservation)}

2.5. 16. To prepare education and awareness programs with community stakeholders, other levels of government, the building industry and the business community to highlight the economic and social advantages of incorporating affordable housing into our communities.

5.2.39. To work with local municipalities and the building and land development industry to develop resident, building owner and operator educational materials and training on sustainable buildings. (resource conservation)

Public education on unsustainable practices and the impact on the environment 
cycling and transit facilities and carpooling options within the community, including local transit routes and schedules (TDM).

7.1. 17. To partner with Metrolinx, the private sector and non-governmental agencies to deliver real-time information on commuting options (TDM).

7.2.17. To work with the Province, Metrolinx and other partners to develop innovative programs that support active transportation, such as cycling safety training, education and information, bicycle sharing programs and bicycle libraries (TDM).

7.3. 33. To work with local municipalities to engage the public on water resource use reduction and conservation, pollution prevention and awareness of lifestyle decisions that can reduce carbon footprints. (resource conservation).

7.4. 5. To work with local municipalities to develop and implement a comprehensive public awareness program, including waste reduction strategies, strategies to increase $4 \mathrm{R}$ participation rates and education regarding the environmental, economic and social effects of waste. (waste)

7.5.9. To investigate the development of an Energy for Tomorrow program that raises awareness of the benefits of energy efficiency and conservation, and renewable energy systems in partnership with local utilities and other stakeholders. (resource conservation)

\section{Summary of Findings:}

Most of the 13 policies identified on educating the public on unsustainable practices were focused on resource conservation, seven of them. Transport planning had three policies with a focus on transport demand management while the remaining three policies were spread among affordable housing, waste management and Brownfield/Infill redevelopment.

\section{Social Sustainability}

7.1.16. To develop a discounted university and college transit pass program with educational institutions. 7.2. 30. To support and implement an equitable transit fare strategy that is integrated with transit services in Affordable transit adjacent regions and with Metrolinx.

The two policies identified in ROP were the only two policies offering transit discount. Email to York Region. 
Cooperative housing - land use provisions that permit multi-family housing development in which residents have both private and shared spaces under cooperative ownership and management.

3.5.15. To encourage local municipalities to adopt policies for an equitable distribution of social housing types, including:

a. municipal and private non-profit and co-operative developments;

b. special needs housing; and,

c. group, rooming, boarding and lodging homes.

I don't think this policy supports land use provision that permit multi-family housing development. Thus, no policies found that explicitly support cooperative housing.

3.5.6. That a minimum $25 \%$ of new housing units across the Region be affordable, and distributed within each local municipality. A portion of these units should be accessible for people with disabilities.

Affordable housing units should include a mix and range of types, lots sizes, unit sizes, functions and tenures to provide opportunity for all household ty pes, including larger families, seniors, and residents with special needs.

3.5.7. That in addition to policy 3.5 .6 , a minimum $35 \%$ of new housing units in Regional Centres and key development areas be affordable, offering a range of affordability for low and moderate income households. 3.5.9. To develop an affordable housing implementation framework in partnership with local municipalities and the development industry to achieve the targets in this Plan.

Affordable Housing - zoning regulations that encourage or require the provision of lower cost housing.
3.5.4. To require that local municipal official plans and zoning by-laws permit a mix and range of housing types, lot sizes, unit sizes, functions, tenures and levels of affordability within each community. The mix and range of housing shall be consistent with Regional forecasts, and intensification and density requirements.

3.5.17. To identify optimal sites for affordable housing early in the development process, particularly in centres and corridors, to maximize affordable housing funding opportunities in consultation with the building industry, non-profit agencies and other stakeholders.

3.5.5. To require that all new secondary plans include a strategy to implement the affordable housing policies found in this Plan. The strategy shall include:

a. specifications on how the affordable housing targets in this Plan will be met;

b. policies to achieve a mix and range of housing types within each level of affordability;

c. policies to ensure larger sized, family units within each housing type and level of affordability; and, 
d. consideration of locations for social housing developments.

5.4.6. That comprehensive secondary plans for Regional Centres and key development areas along Regional Corridors be prepared by local municipalities and implemented in co-operation with the Region and related agencies. These secondary plans shall include a minimum requirement that $35 \%$ of new housing units be affordable, offering a range of compact housing forms and tenures, and intrinsically affordable units for low and moderate income households

3.5.11. That affordable housing initiatives be given priority on suitable publicly owned lands.

5.6.4. That new community areas shall contain a wide range and mix of housing types, sizes and affordability.

3.5.21. To require local municipalities to adopt official plan policies that protect rental housing from both demolition and conversion to condominium or non-residential use, including provisions that would prohibit demolitions or conversions resulting in a rental vacancy rate of less than $3 \%$ in the local municipality. 5.3.3. That local municipalities shall complete and adopt their own intensification strategies based on the York Region 2031 Intensification Strategy and on the Region's Intensification Guide. The local municipal intensification strategies, developed in co-operation with the Region, shall plan for a range and mix of housing, taking into account affordable housing needs

3.5.12. That Housing York Inc. continue to pursue the objective of providing affordable housing units by:

a. managing and expanding the housing portfolio over time;

b. making maximum use of provincial and federal funding opportunities; and,

c. fostering community linkages and partnerships. "

3.5.10. To work with local municipalities, the private sector and other stakeholders to consider innovative financial arrangements to encourage and support the development and maintenance of non-profit and affordable housing, such as:

a. height and density incentives;

b. Community Improvement Plans;

c. grants in lieu of development charges; and,

d. reduced municipal fees and charges.

3.5. 24. To advocate the Province and Federal government to:

a. commit to integrated and sustainable provincial and national housing strategies;

b. provide long term, stable and flexible funding for the provision and maintenance of affordable housing; and,

c. reinstate programs to support and promote the development of affordable housing options such as 


\section{Summary of Findings:}

The Region established affordable housing targets for new housing units for the Region and Regional Centres and key development areas (3.5.6 and 3.5.7), and plans to develop an affordable housing implementation framework to achieve the targets in ROP (3.5.9).

The Region requires that local municipalities permit a mix and range of housing types, lot and unit sizes, and levels of affordability within each community, which need to meet the intensification and density requirements (3.5.4) and incorporate housing needs into intensification strategies (5.3.3). It also requires that affordable housing initiatives be given priority on suitable publicly owned lands (3.5.11) (are these usually Brownfield?) and that optimal sites, particularly in centres and corridors, for affordable housing are identified early in the development process (3.5.17). New community areas need to provide affordable housing (5.6.4), and that all new secondary and comprehensive secondary plans include a strategy to implement affordable housing policies and meet ROP's affordable housing targets (3.5.5 and 5.4.6). Local municipalities are required to protect rental housing with provisions that would prohibit the demolition or conversions, which would result in rental vacancy rate less than $3 \%$ in the local municipality (3.5.21).

The Region plans to work with local municipalities and the private sectors to consider financial arrangements to encourage and support the development and maintenance of affordable housing such as reduced municipal fees and charges (3.5.10) and to work with Housing York Inc to continue to provide affordable housing units (3.5.12). The Region advocates to the Provincial and Federal governments the need for long term, stable and flexible funding for the provision and maintenance of affordable housing (3.5.24).

Encourage:

3.5.8. To encourage the development of intrinsically affordable housing, which includes modest amenities, standard materials, minimal details and flexibility within units.

3.5.13. To encourage the construction of new non-profit housing.

3.5.14. To encourage that special needs housing, and emergency, affordable, and seniors' housing be located in proximity to rapid transit and other human services.

3.5.20. To encourage the construction of new rental units with a full mix and range of unit sizes, including family-sized and smaller units.

3.5.18. To encourage building design that will facilitate subsequent conversion to provide additional 


\begin{tabular}{|c|c|}
\hline & $\begin{array}{l}\text { housing units, such as secondary suites. } \\
\text { 3.5.22. To encourage local municipalities to include "as-of-right" secondary suite policies, on a municipal- } \\
\text { wide basis, in local official plans and zoning by-laws. } \\
\text { Summary of Findings (Encourage): } \\
\text { The Region encourages the private sector and local municipalities to intrinsically develop affordable } \\
\text { housing ( } 3.5 .8 \text { and } 3.5 .13) \text { with secondary units ( } 3.5 .18 \text { and } 3.5 .22) \text { and that it will be located close to transit } \\
\text { and other human services (3.5.14). }\end{array}$ \\
\hline $\begin{array}{l}\text { Adaptive and mitigative } \\
\text { policies to protect urban } \\
\text { communities from climate } \\
\text { change }\end{array}$ & $\begin{array}{l}\text { 2.3.20 development planned and designed to minimize flooding impacts } \\
\text { 2.3.21 development/site alteration prohibited within defined portions of the floodplain, subject to } \\
\text { conservation authority regulations } \\
\text { 2.3.25 Local official plans and zoning by laws to have mapping and policies to identify floodplain } \\
2.3 .27 \text { To work with local municipalities and conservation authorities to prepare for climate change impacts } \\
\text { by ensuring public health and safety, infrastructure security, emergency services, and that evacuation routes } \\
\text { are maintained during flood events. } \\
\text { 2.3.28. That emergency management plans be updated regularly and reflect disaster response best practices } \\
\text { for severe weather events, including flooding. } \\
\text { 2.3. 29. To work with local municipalities, conservation authorities and other partners to ensure that climate } \\
\text { change effects are considered in flood management and natural } \\
\text { heritage areas. } \\
\text { 3.1. } 6 \text {. To work with local municipalities to understand the impacts of climate change on the health and } \\
\text { well-being of residents. } \\
\text { 3.1.7. To design communities to be more resilient to the effects of climate change. } \\
\text { 3.2. } 2 \text { To prepare a climate change adaptation action plan in keeping with the York Region Sustainability } \\
\text { Strategy: Towards a Sustainable Region } \\
\text { 3.2.7. To work with partners such as the GTA Clean Air Council to conduct research, develop toolkits and } \\
\text { share information on air quality and climate change impacts. } \\
\text { 3.2.9 and 3.2.10. To work with other levels of government, agencies, and stakeholders to identify the links } \\
\text { between climate change, community planning and public health. } \\
\text { 3.2.11. To work with other levels of government, agencies and stakeholders to develop climate change }\end{array}$ \\
\hline
\end{tabular}


adaptation measures that address such issues as urban heat island effect, infrastructure resiliency, emergency preparedness, vector-borne diseases, and extreme-weather event responses.

3.2.12To work with the Province to increase air quality monitoring stations in York Region and to improve air quality monitoring.

3.2.13. To investigate emissions trading and carbon offsets to finance and showcase clean air initiatives in consultation with the Province and Federal government.

6.3.15. To promote agricultural practices, which minimize impacts on air quality and climate change, such as no-till farming.

7.3.30. That the planning and design of water and wastewater infrastructure will consider potential impacts from climate change.

\section{Summary of Findings:}

Ten policies were coded as adaptive and mitigative policies to protect urban communities from climate change because they had the term "climate change" in the policy statement/description. Four additional policies were also considered as adaptive and mitigative policies to protect urban communities from climate change because they focused on the identification of flood plains/lands, prohibiting development within defined floodplains, planning and designing development to minimize flooding impacts and developing emergency management plans for severe weather events including flooding $(2.3 .20,2.3 .21,2.3 .25,2.3 .28)$. Two of the ten climate change policies also included flood events and flood management as part of the preparations required to manage climate change effects and impacts (2.3.27 and 2.3.29). One of the climate change policies focused on reducing the impact from climate change by promoting agricultural practices which minimize climate change such as no-till farming (6.3.15). The remaining policies focused on preparing for the effects and impacts of climate change by studying and sharing the impacts of climate change and its links to community planning and public health $(3.1 .6,3.2 .10,3.2 .11,3.2 .7)$, by putting a climate change adaptation action plan in place (3.2.2), by designing water and wastewater infrastructure which will consider potential impacts from climate change (7.3.30) and overall designing communities that are more resilient to the effects of climate change (3.1.7).

Individual and collective actions designed to identify and address issues of public

3.1.4. To encourage citizen engagement and shared responsibility in decisions affecting individual and community heal th and well-being.

3.1.9. To encourage a strong sense of conmunity and belonging through volunteerism. 

accountable and transparent government.

8.1.2. To provide sufficient information about amendment applications and engage the public using methods including public meetings, information centres, open houses, stakeholder workshops, newspaper, radio and television advertising, e-mail, internet, telephone and written correspondence.

8.1.3. To engage, consult and partner, as appropriate, with First Nations and Métis Nation communities when considering planning applications and studies that may affect their interests.

8.1.4. To ensure public meetings and materials are accessible for people with disabilities.

\section{Summary of Findings:}

Engage public, people with disabilities and First Nations and Métis Nation communities $(3.1 .4,8.1 .2,8.1 .3$, 8.1.4) and encourage volunteerism (3.1.9). And to ensure the government provides sufficient information, is transparent and consult with the public and the Province in a timely manner (8.1.1,8.1.2). 


\section{References}

Abolina, K. and Zilans (2002). Evaluation of Urban Sustainability in Specific Sectors in Latvia. Environment. Development and Sustainability, 4, 299-314.

Anonymous (2010, April 30). Province Still Spending on Roads. It's a Tough Time for Transit, but Not the End of the World, Opinion, April 28. Toronto Star, pp. 20.

Anonymous (2010, June 7), Rein in Durham. Toronto Star, pp. A14.

Berke, P. and Manta Conroy, M. (2000). Are We Planning for Sustainable Development? An Evaluation of 30 Comprehensive Plans. Journal of The American Planning Association, $66(1), 1381-1396$.

Boyd, D.R. and Suzuki, D. (2008). Green Guide. Vancouver: Greystone Books: David Suzuki Foundation.

Chakrabarty, B.K. (2001). Urban Management: Concepts, Principles, Techniques and Education. Cities, 18(5), 331-345.

City of Brampton (2010). Government Responsibilities. Accessed on July 20, 2010.

Retrieved from http//www.brampton.ca/en/City-Hall/Pages/GovernmentResponsibility.aspx

Clean Air Partnership (2010). Bike and Pedestrian Transportation Action Plans Scan Greater Toronto Area Jurisdictions. Toronto: Clear Air Partnership.

Collier, D. (1991). The Comparative Method: Two Decades of Change. In D.A. Rustow and K. Erickson (Eds.), Comparative Political Dynamics, Global Research Perspectives (731). New York: HarperCollins.

Conroy, M. (2006). Moving the Middle Ahead Challenges and Opportunities of Sustainability in Indiana, Kentucky and Ohio. Journal of Planning Education and Research, 26, 18-27. 
Cooperative Housing Federation of Toronto (2010). About Co-op Housing. Accessed on July 21,2010 . Retrieved from http://www. coophousing com/about/about_housing. asp

Criscione, P. (2009, October 16). Region Takes in Public Input on Growth Management. Caledon Enterprise, pp. 1 .

Dale, A. (2001). At the Edge: Sustainable Development in the 21st Century. UBC Press. Vancouver.

EMA Canada Inc. (2008). Regional Municipality of Peel - Background Paper on Sustainability.

Environment Canada (2006). Evaluation of the One Tonne Program. Accessed on July 11, 2010. Retrieved from http://www.ec.gc.ca/ae-ve/default.asp?lang=En\&n=E0530F2A$1 \&$ offset $=5 \&$ toc $=$ show

Environmental Commissioner of Ontario (2007) 2006/07 Annual Report - Reconciling our Priorities. Commissioner's Introductory Remarks to the Legislature. Accessed on July 6, 2010. Retrieved from http://www.eco.on.ca/eng/index.php/pubs/eco-publications/200607-annual-report/remarks.php

Federation of Canadian Municipalities (2009). Partners for Climate Protection. Accessed on November 6, 2009. Retrieved from http://gmf.fcm.ca/Partners-for-ClimateProtection

Fleischer, D. (2010, April 30). Rapid transit projects may be delayed. Vaughan Citizen, pp. 1.

George, C. (2001). Spatial Planning - Sustainability appraisal for sustainable development: integrating everything from jobs to climate change. Impact Assessment and Project Appraisal, 19(2), 95-106.

Global Development Research Centre. 1998. Wingspread Statement on the Precautionary Principle. Accessed on August 31, 2010. Retrieved from http://www.gdrc.org/u- 
gov/precaution-3.html

Government of Ontario (1990a). E-laws. Planning Act. Accessed on July 26, 2010.

Government of Ontario (1990b). E-laws. Ontario Water Resources Act. Accessed on July 26, 2010.

Government of Ontario (2001). E-laws. Oak Ridges Moraine Conservation Act. Accessed on July 26,2010 .

Government of Ontario (2005a). E-laws. Ontario Clean Water Act. Accessed on July 26, 2010 .

Government of Ontario (2005b). E-laws. Greenbelt Act. Accessed on July 26, 2010.

Government of Ontario (2005c). E-laws. Places to Grow Act. Accessed on July 26, 2010.

Government of Ontario (2008a). E-laws. Green Energy Act. Accessed on July 26, 2010.

Government of Ontario (2008b). E-laws. Lake Simcoe Protection Act. Accessed on July 26, 2010 .

Great Lakes United (2010). Ontario Water Conservation Alliance Launched. Accessed on July 10, 2010. Retrieved from http://www.glu.org/en/press/ontario-water-conservationalliance-launched

Greening Greater Toronto (2010). Green Procurement. Accessed on July 10, 2010. Retrieved from http://www.greeninggreatertoronto.ca/initiatives/procurement.asp

GTAA Partners in Project Green (2010). Greening the Bottom Line in the Pearson EcoBusiness Zone. Accessed on July 10, 2010. Retrieved from http://www.partnersinprojectgreen.com/

Hammond, G.P (2006). 'People, planet and prosperity': The determinants of humanity's environmental footprint. Natural Resources Forum, 30, 27-36.

Hempel, L.C. (1996). Chapter 1: Between Two Centuries. Environmental Governance: the Global Challenge (1-28). Washington, DC: Island Press.. 
Hodge, G. (2003). Planning Canadian Communities: An Introduction to the Principles, Practice and Participants (4th ed.). Toronto: Nelson Thomson Learning.

Hodge, T. (1997). Toward a Conceptual Framework for Assessing Progress Towards Sustainability. Social Indicators Research, 40, 5-98.

Hofmann, R. 2000. Introduction. SAMS, 39, 185-189.

Human Resources and Skills Development Canada (2010). Indicators of Well-Being in Canada. Accessed on July 10,2010. Retrieved from http://www4.hrsdc.gc.ca/.3ndic.1t.4r@-eng.jsp?iid=23

International Council for Local Environmental Initiatives (ICLEI), Local Agenda 21 Initiative, International Development Research Centre (IDRC) and United Nations Environment Program (UNEP) Department of Information and Public Affairs (1996). The Local Agenda 21 Planning Guide An Introduction to Sustainable Development Planning. Canadian Cataloguing in Publication Data.

Jepson, E. (2004). The Adoption of Sustainable Development Policies and Techniques in U.S. Cities. Journal of Planning Education and Research, 23, 229-241.

Lafferty, W.M. and Hovden, E. (2003). Environmental Policy Integration: Towards an Analytical Framework. Environmental Politics, 12(3), 1-22.

Lambert and Boons (2002). Eco-industrial parks: stimulating sustainable development in mixed industrial parks. Technovation, 22, 471-484.

Leech, N.L. and Onwuegbuzie, A.J. (2007). An Array of Qualitative Data Analysis Tools: A Call for Data Analysis Trangulation. School Psychology Quarterly, 22(4), 557-584.

Lozano, R. (2008). Envisioning sustainability three-dimensionally. Journal of Cleaner Production, 16, 1838-1846.

Martin-Robins, A. (2007, December 21). Rural Mayors Slam Provincial Growth Plan. Caledon Enterprise, pp.1. 
McKay, R.B. (2000). Consequential Utilitarianism: Addressing Ethical Deficiencies in the Municipal Landfill Siting Process. Journal of Business Ethics, 26. 289-306.

Meadows. D.H. et al. (1972). Limits to Growth: A Report for the Club of Rome's Project on the Predicament of Mankind. New York: Universe Books

Meadows, D.H. et al. (2005). The Limits to Growth: The 30-year Update $\left(3^{\text {rd }}\right.$ ed.). London : Earthscan.

Mebratu, D. (1998). Sustainability and Sustainable Development: Historical and Conceptual Review. Environment Impact Assessment Review, 18, 493-520

Metrolinx (2010a). The Big Move, Strategies. Accessed on July 2, 2010. Retrieved from http://www.metrolinx.com/thebigmove/strategies/strategy $10 \mathrm{html}$

Metrolinx (2010b). The Big Move, A Vision for the Future. Accessed on July 2, 2010. Retrieved from http:/www.metrolinx.com/thebigmove/vision/index html

Ministry of Agriculture, Food and Rural (2010). Agricultural, Statistics, County Profiles. Accessed on July 15, 2010. Retrieved from http://www.omafra.gov.on.ca/english/stats/county/index.html

Ministry of Energy and Infrastructure (2006). ReNew Ontario Progress Report 2006. Accessed on April 10, 2010. Retrieved from http://www.mei.gov. on ca/en/infrastructure/framework/?page=renew

Ministry of Energy and Infrastructure (2007). ReNew Ontario Progress Report 2007. Accessed on: April 10, 2010. Retrieved from http $/ /$ www.mei.gov.on.ca/en/infrastructure/framework/page=renew Ministry of Energy and Infrastructure (2009a). Infrastructure Stimulus Fund in Ontario. Accessed on July 10, 2010. Retrieved from http://www.news.ontario.ca/mei/en/2009/06/infrastructure-stimulus-fund-in-ontario.html 
Ministry of Energy and Infrastructure (2009b). Recreational Infrastructure Canada. Accessed on July 10, 2010. Retrieved from http://www.news.ontario.ca/mei/en/2009/07/hundreds-of-projects-to-receive-governmentfunding-for-recreational-infrastructure.html

Ministry of Energy and Infrastructure (2009c). Knowledge Infrastructure Program. Accessed on July 10,2010 . Retrieved from http://www.news.ontario.ca/tcu/en/2009/09/governments-of-canada-and-ontarioannounce-knowledge-infrastructure-projects-underway-groundbreaking.html

Ministry of Energy and Infrastructure (2010a). Building Canada Fund-Communities Component. Accessed on July 10, 2010. Retrieved from http://www.news ontario.ca/mei/en/2009/06/canada-ontario-building-canada-fund--communities-component.html

Ministry of Energy and Infrastructure (2010b). Conservation Legislation. Accessed on July 21, 2010. Retrieved from http://www.mei.gov.on.ca/en/energy/conservation/?page=conservation-legislation Ministry of Energy and Infrastructure (2010c). Places to Grow Awards. Accessed on July 21, 2010. Retrieved from https://www.placestogrow.ca/index.php?option=com_content\&task=view\&id=13\&Itemid $=21$

Ministry of Environment (2009). Water. Accessed on July 17, 2010. Retrieved from http://www.ene.gov.on.ca/en/water/index.php

Ministry of Municipal Affairs and Housing. (2005). Provincial Policy Statement. Toronto: Queen's Printer for Ontario. 
Ministry of Municipal Affairs and Housing. (2007). Planning and Conservation Land Statute Law Amendment Act, 2006 Bill 51. Accessed on June 10, 2010. Retrieved from http://www.mah.gov.on.ca/Asset234.aspx

Ministry of Municipal Affairs and Housing. (2009). Land Use Planning. Retrieved on June 12, 2010. Retrieved from http:/www.mah.gov.on.ca/Page1759.aspx

Ministry of Municipal Affairs and Housing. (2010). Local Government.

Accessed on June 1, 2010. Retrieved from: http:/www.mah.gov.on ca/Page5384.aspx

Ministry of Public Infrastructure Renewal (2006). Places to Grow Growth Plan for the Greater Golden Horseshoe. Ontario: Queen's Printer.

Ministry of Transportation (2010). Ontario Transportation Demand Management Municipal Grant Program: A Program to Encourage Cycling, Walking, Transit, and Trip Reduction. Accessed on July 20,2010. Retrieved from http:/www.mto.gov.on.ca/english/sustainability/programs/tdm-grant.shtml

Mitham, P. (2009). Eco-industrial zones: Sustaining the wealth of industrial developments. Fresh Outlook Foundation: Building Sustainable Communities e-Zine, (Winter).

National Roundtable on the Environment and the Economy (NRTEE) (2004). About Measuring Sustainability. Accessed on July 2, 2010. Retrieved from http://www,sustreport.org/indicators/about.html

Newman, P. and Jennings, I. (2008). Cities as Sustainable Ecosystems; Principles and Practices. Washington: Island Press.

Nolan, D. (2010, April 8). \$139m investment in Ontario road work; Highway 403 among local projects. The Spectator, pp. A7.

Ontario Non-Profit Housing Association (ONPHA). (2010). About Non-Profit Housing, Municipalities and Housing. Accessed on July 2, 2010. Retrieved from 


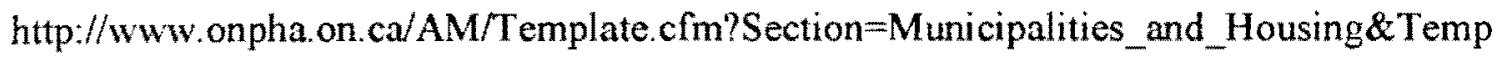
late $=/ \mathrm{CM} / \mathrm{HTMLDisplay} . \mathrm{cfm} \&$ ContentID $=8069$

Ontario Greenbelt Alliance (2009). Greenbelt 2.0: Furthering the Vision of a Greener, More Livable Golden Horseshoe. Accessed on July 11, 2010. Retrieved from http://greenbeltalliance.ca/?q=mediacentre/readnews $/ 547$

Parkinson, R. and Roseland, M. (2002). Local Environment. Leaders of the Pack: An Analysis of the Canadian 'Sustainable Communities' 2000 Municipal Competition. Local Environment, 7(4), 411-429.

Payton et al. (2008). Valuing the benefits of the urban forest: a spatial hedonic approach. Journal of Environmental Planning and Management, 5I(6), 717-736.

Pediaditi, K. et al. (2006). Sustainability Evaluation for Brownfield Redevelopment. Proceedings of the Institution of Civil Engineers: Engineering Sustainability, 159(1), 310.

Pierce, J.T. and Dale, A. (Eds.) (1999). Communities, Development, and Sustainability across Canada. Vancouver: UBC Press.

Portney, K. (2002). Taking sustainable cities seriously: a comparative analysis of twenty-four US cities. Local Environment, 7(4), 363-380.

Public Works and Govemment Services Canada (2009). Policy on Green Procurement. Accessed on July 20, 2010. Retrieved from http:/www.tpsgc-pwgsc.gc.ca/ecologisationgreening/achats-procurement/politique-policy-eng.html

Pucher (1983). Who benefits from transit subsidies? Recent evidence from six metropolitan areas. Transportation Research Part A: General, 17(1), 39-50.

Rai, S. (2010, April 22). Suburban sprawl should be election issue in Vaughan, Vaughan Citizen, pp.1.

Region of Peel (2009). Official Plan-Office Consolidation, November 2008. Accessed on 
April 1. 2010. Retrieved from

http://www.peelregion.ca/planning/officialplan/download htm

Region of Peel (2010a). Peel Data Centre. Accessed on July 19, 2010. Retrieved from

http://www peelregion.ca/planning/pdc/data/quick facts.htm

Region of Peel (2010b). Waste Management-2010 Budget Document. Accessed on July 18, 2010. Retrieved from http://www.peelregion ca/finance/2010-budget/pdfs/8-wastemanagement-budget.pdf

Region of Peel (2010c). Waste Management. Accessed on July 18,2010. Retrieved from http://www.peelregion.ca/pw/waste/overview.htm

Region of Peel (2010d). Region Official Plan Review. Accessed on July 6, 2010. Retrieved from: http://www.peelregion.ca/planning/officialplan/2007offplan-review.htm

Region of York (2009). York Region Official Plan December 16, 2009. Accessed on April 2, 2010. Retrieved from

http:/www york.ca/Departments/Planning+and+Development/Growth + Management/defa ult+Growth+Managementhtm

Region of York (2010a). 2009 Greening Strategy Achievements - Report No. 3 of the Transportation Services Committee Regional Council Meeting of March 25, 2010. Accessed on May 10,2010. Retrieved from http:/www.york.ca/NR/rdonlyres/iv3fskwprqrxpj7fr3bt223gtq2cpgawvto44uqodpptbg 564 hacrij5xvnjlfbpd5wrgmmqwwq43fdpkkxs32hjmg/rpt $+3+\mathrm{cls}+7$.pdf

Region of York (2010b). York Region 2031 Land Budget. Report No. 2 of the Planning and Economic Development Committee Regional Council Meeting of March 25, 2010. Accessed April 20, 2010. Retrieved from http://www.york.ca/NR/rdonlyres/hwc76oxkazaormpnnz5bw42nuwrgijgl3ruf7lv6gacgnjz gunl6soxzhyg676uo24ldswvv2zuic6unhjlidrpja/York+Region+2031+Land+Budget+and 
+ Attachment $+1 . p d f$

Region of York. (2010c). Growth Management. Accessed May 10, 2010. Retrieved from http:/www.york.ca/Departments/Planningtand+Development/Growth+Management/Gro wth+Management+Public +Meeting.htm

Riffe et al. (Eds.) (2005). Analyzing Media Messages Using Quantitative Analysis in Research. New Jersey: Lawrence Erlbaum Associates, Publishers.

Rihoux, B. (2006). Qualitative Comparative Analysis and Related Systematic Comparative Methods - Recent Advances and Remaining Challenges for Social Science Research. International Sociology, 21(5), 679-706.

Robinson, J. and Legge, R. (1990). Defining a sustainable society: values, principles and definitions. Alternatives, 17.2(July/August), 36-46.

Robinson, P.J. (2006). Canadian Municipal Response to Climate change: measurable progress and persistent challenges for planners. Planning Theory and Practice Interface, $7(2), 218-223$

Robinson, P.J. (2008). Urban Sustainability in Canada: The Global-Local Connection. In Gore, C. and Stoett, P. (Eds.), Environmental challenges \& Opportunities: Local-Global Perspectives on Canadian Issues (pp. 159-181). Toronto: Emond Montgomery Publications.

Roseland, M. (2005). Towards Sustainable Communities: Resources for Citizens and Their Governments. Gabriola Island, BC: New Society Publishers.

Ross, N. (2008). Places to Grow, the McGuinty government dictates where people will live. Alternatives Journal, 34(3), 25.

Runhaar et al. (2009). Sustainable urban development and the challenge of policy integration: an assessment of planning tools for integrating spatial and environmental planning in the Netherlands. Environment and Planning B: Planning and Design, 36, 417-431 
S. de Wilde, A (2004). Space use optimisation and sustainability - environmental comparison of international cases. Journal of Environmental Management, $73.91-101$

Saha, D. and Paterson, R. (2008). Local government efforts to promote the "Three Es" of sustainable development. Journal of Planning Education and Research, 28, 21-37.

Schor, J.B. and Taylor, B. (Eds.) (2003). Sustainable Planet: Solutions for the Twenty-first Century. Centre for a New American Dream. Boston: Beacon Press.

Statistics Canada (2001). Dictionary (online). Accessed on July 31, 2010, Retrieved from http:/www12.statcan.gc.ca/english/census01/products/reference/dict/atoz.htm

Statistics Canada (2006). Community Profles. Retrieved from http://www12.statcan.gc.ca/census-recensement $2006 / \mathrm{dp}-\mathrm{pd} / \mathrm{prof} / 92-$ 591/index. cfm?Lang=E

Tarasofsky, R. (2006). Canada's Progress in Addressing the Strategic Imperatives set out in "Our Common Future". Accessed June 10, 2009. Retrieved from: http://search iisd.org/search?q=Tarasofsky,\%20R.\%20(c.\%202006).\%20Canada's\%20Pro gress $\% 20$ in $\% 20$ Addressing $\% 20$ the $\% 20$ Strategic $\% 20$ Imperatives $\% 20 \&$ sort=date $\% 3$ AD $\%$ 3AL\%3Ad1\&output=xml_no_dtd\&oe=UTF-8\&ie=UTF8\&client=default_frontend\&proxystylesheet=default_frontend\&site=default_collection Tindal, C. R and Tindal, S.N. (2004). Local Government in Canada (6th ed.). Toronto: Nelson.

Tsenkova, S. and Damiani, R. (2009). Urban sustainability: Learning from evaluation of community plans in Calgary. Canadian Journal of Urban Research, 18(1), 24-47.

United Nations Department of Economic and Social Affairs (2007). World Urbanization Prospects 2007 Revision. Accessed on December 10, 2009. Retrieved from http:/www.un.org/esa/population/publications/wup2007/2007wup.htm 
United Nations Economic and Social Development (2002). Johannesburg Plan of Implementation. Accessed on April 1, 2010. Retrieved from http://www.un.org/esa/sustdev/documents/WSSD_POI_PD/English/POITochtm International Council for Local Environmental Initiatives (ICLEI). (2010). Local governments for sustainability. Accessed on May 1, 2010. Retrieved from http://www.iclei.org/index.php?id=about

Urban Strategies Inc. (2005). Application of a Land-Use Intensification Target for the Greater Golden Horseshoe (Places to Grow Act supporting documents). Accessed on: May 1, 2010. Retrieved from https://www.placestogrow.ca/images/pdfs/IntensificationTargetForGGH.pdf Watt, L. (2006, November 1) Cash Extends Landfill. Barrie Edition, pp. A8. Wekerle et al. (2007). Nature as a Cornerstone of Growth: Regional and Ecosystems Planning in the Greater Golden Horseshoe. Canadian Journal of Urban Research, 16(1), 20-38

Wellington, A. ES8921 Environmental Law and Policy. Ryerson University, September 25, 2006. Lecture.

Woodrum, E. (19840. "Mainstreaming" Content Analysis in Social Science: Methodological Advantages, Obstacles, and Solutions. Social Science Research, 12, 1-19.

World Commission on Environment and Development (1987). Report of the World Commission on Environment and Development: Our Common Future. Accessed on August 11, 2009. Retrieved from http://www.un-documents.net/wced-ocf.htm 


\section{Glossary}

Built Up Areas: All land within the built boundary. Built Boundary are the limits of the developed urban area as defined by the Minister of Public Infrastructure Renewal in accordance with Policy 2.2.3.5. (Ministry of Public Infrastructure Renewal, 2006).

Core areas of the Greenland System: The Core Areas consist of (2.3.2.2) (Region of Peel, 2009):

- Significant wetlands (Class 1-3)

- Significant coastal wetlands

- Core woodlands

- Environmentally Sensitive or Significant Areas;

- Provincial Life Science Areas of Natural and Scientific Interest;

- Significant habitats of threatened and endangered species

- Escarpment Natural Areas of the Niagara Escarpment Plan; and

- Core valley and stream corridors.

Designated Greenfield Areas: The designated area that was outside of the built-up area as of June 2006 as defined by the Province's Built Boundary in Places to Grow: Growth Plan for the Greater Golden Horseshoe (Region of York, 2009).

Employment lands: lands designated for clusters of business and economic activities including, but not limited to, manufacturing, warehousing, offices, and associated retail and ancillary facilities (Region of Peel, 2009).

Intensification Corridors: Intensification areas along major roads, arterials or higher order transit corridors that have the potential to provide a focus for higher density mixed-use development consistent with planned transit service levels (Ministry of Public Infrastructure Renewal, 2006).

Local Centres and Corridors: Local Centres and Corridors are important components of the local urban structure. Local Centres are focal points for residential, human services, commercial and office activities for the surrounding community and play a supporting role to Regional Centres and Corridors and enhance the network of connectivity throughout York Region. Some of these centres include Woodbridge, Downtown Newmarket, Keswick, Old Unionville, and Downtown Richmond Hill. Given the diversity of communities across York Region, Local Centres can vary greatly in size, nature and characteristics. Local Centres are also used to reflect the culture and history of York Region through heritage streetscapes and are the locations for a number of festivals. Certain Local Corridors, which may be Regional arterial streets, in existing and proposed urban areas, have the potential for intensive and mixed-use land development, supported by public transit services. Local Corridors link Regional and Local Centres and may be identified as routes for transit services and facilities (Region of York, 2009).

Major Transit Station Areas: The area including and around any existing or planned rapid transit station or the area including and around a major bus depot in an urban core. Station 
areas are generally defined as the area within an approximate 500 metre radius of a transit station, representing about a 10-minute walk (Region of Peel, 2009).

Regional Centres and Corridors: The Regional Centres are planned as the most important and intense concentrations of development within the Region. They are vibrant urban places for living, working, shopping, entertainment, cultural identity and human services. The four Regional Centres are strategically located in Markham, Newmarket, Richmond Hill and Vaughan, and are connected along the Regional Corridors to enhance the mobility of people and goods to, from and within these places. These areas will provide a diverse and compatible mix of land uses, including residential and employment uses, to support vibrant neighbourhoods. These strategic locations are based on an intensification framework that recognizes that the highest density and scale of development will occur in the Regional Centres followed by the Regional Corridors. The Regional Centres and Corridors are the focus of this city building approach to sustainable growth and place making, and are the foundation of the Region's urban structure (Region of York, 2009).

Urban Growth Centres: Urban growth centres are planned (Ministry of Public Infrastructure Renewal, 2006):

- as focal areas for investment in institutional and region-wide public services, as

- well as commercial, recreational, cultural and entertainment uses

- to accommodate and support major transit infrastructure

- to serve as high density major employment centres that will attract provincially,

- nationally or internationally significant employment uses

- to accommodate a significant share of population and employment growth.

Urban Nodes: Urban Growth Centres in Region of Peel (Region of Peel, 2009).

Urban System: The Urban System is composed of a variety of communities that contain diverse living, working and cultural opportunities. The Urban System in Peel consists of lands within the 2031 Regional Urban Boundary as shown on Schedule D of the Regional Official Plan (Region of Peel, 2009). 